SIMONE DE LARA TEIXEIRA UCHOA FREITAS

CARACTERÍSTICAS DAS EMPRESAS DE SERVIÇOS DE ENGENHARIA E A CRIAÇÃO DE CAPACITAÇÕES DINÂMICAS: O PAPEL INDUTOR DA PETROBRAS 


\section{CARACTERÍSTICAS DAS EMPRESAS DE SERVIÇOS DE ENGENHARIA E A CRIAÇÃO DE CAPACITAÇÕES DINÂMICAS: \\ O PAPEL INDUTOR DA PETROBRAS}

Dissertação apresentada à Escola Politécnica da Universidade de São Paulo para obtenção do título de Mestre em Engenharia

Área de concentração:

Engenharia de Produção

Orientador: Prof. Dr. Mario Sergio Salerno 


\section{DEDICATÓRIA}

Ao meu orientador, Prof. Dr. Mario Sergio Salerno, pelo aprendizado que me fez crescer também como pessoa e pela confiança depositada em mim nos momentos mais difíceis.

Meu eterno carinho e gratidão. 


\section{AGRADECIMENTOS}

A Deus, pela fé que habita em mim.

Ao Wagner, meu amor e melhor amigo, pelo apoio, paciência e por nunca ter deixado de acreditar que eu conseguiria.

A Dra. Silvia Broniscer, que tem cuidado de mim com muita dedicação e carinho.

Aos amigos e amigas que torceram por mim e que sentiram minha falta nas festas e fins de semana. São muitos, e cada um ocupa um lugar especial em meu coração.

A minha família, em especial William e Débora.

Aos amigos e amigas que fiz na sala de TTO, pelas longas conversas e dicas.

Aos funcionários do Departamento de Engenharia de Produção: Lídia, Priscila, Patrícia, Olívia, Camila, Samy, Rafaela, Rose, Antônio e Dona Ana.

Aos professores que tiveram participação nesta conquista: Prof. Dr. Afonso Fleury, Prof. Dr. Roberto Marx, Prof. Dr. Amato Neto, Prof. Dr. Davi Nakano, Prof. Dr. Renato Garcia, Prof. Dr. Fernando Laurindo e Prof. Dr. Roberto Sbragia.

A todas as empresas que contribuíram para que os estudos de caso fossem realizados, pois, sem elas, não haveria resultado.

Ao Ipea, pela oportunidade de participar do projeto que deu origem a este trabalho: Lenita, João De Negri e Fernanda, muito obrigada.

Em especial ao Prof. Dr. Mario Sergio Salerno, também orientador, por dividir comigo parte do seu tempo, do seu conhecimento e pelas oportunidades que me disponibilizou. 
EPÍGRAFE

"A competitividade de um país não começa nas indústrias ou nos laboratórios de engenharia. Ela começa na sala de aula."

Lee lacocca 


\section{RESUMO}

O objetivo desta dissertação é analisar como se dá a construção das capacitações dinâmicas nas empresas fornecedoras de serviços de engenharia, tendo como premissa o papel indutor da Petrobras.

A decisão de personificar a Petrobras nesta pesquisa deu-se a partir da participação da autora em um projeto realizado junto ao Ipea que, contratado pela Petrobras, analisou os impactos tecnológicos das ações da Petrobras nas empresas de serviços de engenharia. Os resultados do projeto mostraram que tais empresas tem papel de destaque quando comparadas às demais empresas do setor. Dados como o aumento do volume de empregos, da massa salarial ou da capacitação tecnológica e organizacional das empresas analisadas, comprovaram o alto impacto dos contratos da Petrobras nas relações de parceria e, principalmente, no desenvolvimento das competências das empresas do setor de serviços de engenharia no Brasil.

A presente pesquisa foi desenvolvida a partir do estudo de múltiplos casos, realizados em duas etapas: a primeira etapa objetivou verificar as características das empresas de serviços de engenharia e sua evolução em decorrência dos contratos com a Petrobras; a segunda etapa objetivou verificar como as empresas de serviços de engenharia criam suas capacitações dinâmicas a partir das relações contratuais e pré-contratuais com a Petrobras.

A literatura a respeito das capacitações dinâmicas, de modo geral, está atrelada ao conceito de rotina, que constitui a forma mais importante de estocagem do conhecimento específico da organização. Através da absorção e do acúmulo do conhecimento as rotinas existentes são modificadas, aperfeiçoadas, caracterizando assim uma forma dinâmica da reprodução do conhecimento, capaz de se moldar de acordo com o estado de complexidade do ambiente.

Como resultado, apresentam-se dados que demonstram a evolução técnica e o crescimento estrutural nas empresas de serviços de engenharia que criaram suas capacitações através da estocagem do conhecimento sob a forma de rotina. 


\begin{abstract}
The objective of this dissertation is to analyze how the construction of dynamic capabilities are in companies that provide engineering services, taking as its premise the inductive role of Petrobras.

The decision to personify Petrobras in this study, took place from the author's participation in a project carried out by the Ipea that contracted by Petrobras, analyzed the impacts of technological Petrobras' shares in companies of engineering services. The project results showed that these companies have an important role when compared to other companies. Data such as the increasing of volume of jobs, payroll or technological capability and organizational enterprises analyzed, confirmed the high impact of contracts with Petrobras, especially, in developing the skills of engineering services companies in Brazil.
\end{abstract}

This research was developed from the study of multiple cases, conducted in two stages: the first step aimed to determine the characteristics of engineering services companies and their evolution as a result its contracts with Petrobras, the second step aimed to determine how engineering services companies created their dynamic capabilities from contractual and pre-contract relation with Petrobras.

The literature about dynamic capabilities, in general, is tied to the concept of routine, which is the most important form of storage of specific knowledge of the organization. Through the absorption and accumulation of knowledge, the existing routines are modified, improved, characterizing a dynamic form of reproduction of knowledge, able to mold itself according with the state of complexity of the environment.

As a result, we present data demonstrating the technical development and growth in structural engineering services companies that have created their capabilities by storing the knowledge in the form of routine. 


\section{LISTA DE ILUSTRAÇÕES}

llustração 1 - Modelo simplificado de entradas/saídas de rotinas organizacionais e capacitações. 33

Ilustração 2 - Ciclo de evolução do conhecimento ...............................................38

Ilustração 3 - Limite de valores FEED ...................................................................77 


\section{LISTA DE QUADROS}

Quadro 1 - Síntese da construção do tema e sua justificativa...............................10

Quadro 2 - Aprendizagem, capacitações dinâmicas, e rotinas operacionais 11

Quadro 3 - Natureza das contribuições no campo da aprendizagem organizacional .13

Quadro 4 - Aprendizagem organizacional versus organizações que aprendem.......14

Quadro 5 - Definições de aprendizagem organizacional ....................................16

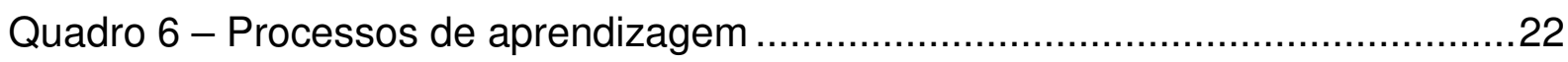

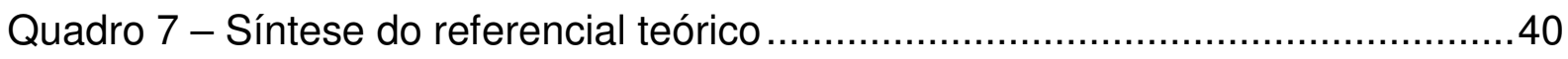

Quadro 8 - Síntese da metodologia e procedimentos adotados nesta pesquisa......48

Quadro 9 - Respondentes da segunda fase da pesquisa na CNC ........................66

Quadro 10 - Mecanismos de aprendizagem CNC ……....................................8

Quadro 11 - Indicadores de capacitação dinâmica - CNC ......................................81

Quadro 12 - Respondentes da segunda fase da pesquisa na GPR......................85

Quadro 13 - Mecanismos de aprendizagem GPR ……..................................... 97

Quadro 14 - Indicadores de capacitação dinâmica - GPR .......................................98

Quadro 13 - Respondentes da segunda fase da pesquisa na KAT.......................101

Quadro 16 - Mecanismos de aprendizagem KAT ...........................................113

Quadro 17 - Indicadores de capacitação dinâmica - KAT ....................................114 


\section{LISTA DE GRÁFICOS}

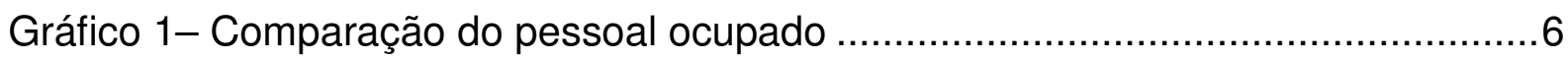

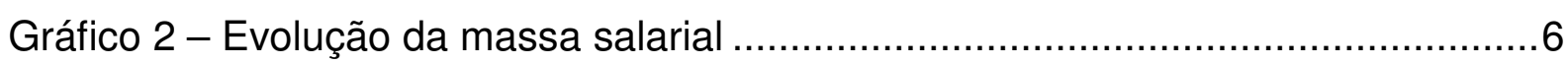

Gráfico 3 - Evolução do pessoal ocupado com $3^{\circ}$ grau .......................................

Gráfico 4 - Evolução da proporção de engenheiros nas empresas contratadas ........8

Gráfico 5 - Porcentagem de faturamento com projetos Petrobras..........................60 


\section{LISTA DE TABELAS}

Tabela 1 - Relação de empresas, cargos e dados das entrevistas .........................50

Tabela 2 - Ano do primeiro contrato com a Petrobras ...........................................52

Tabela 3 - Porcentagem de faturamento com projetos da Petrobras .......................59

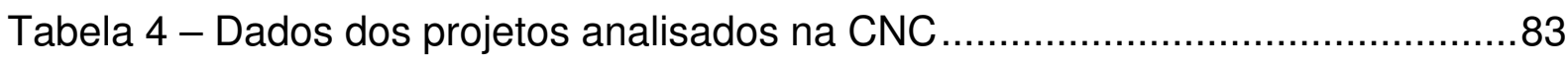

Tabela 5 - Dados dos projetos analisados na GPR .............................................100

Tabela 6 - Dados dos projetos analisados na KAT ..........................................116 


\section{LISTA DE ABREVIATURAS E SIGLAS}

$\begin{array}{ll}\text { BAD } & \text { Boletim de Avaliação de Desempenho } \\ \text { CENPES } & \text { Centro de Pesquisa } \\ \text { CNAE } & \text { Classificação Nacional de Atividades Econômicas } \\ \text { COMPERJ } & \text { Complexo Petroquímico do Rio de Janeiro } \\ \text { DUI } & \text { Doing, Using and Interacting } \\ \text { EPC } & \text { Engineering, Procurement \& Construction } \\ \text { FEED } & \text { Front and Engineering Design } \\ \text { GED } & \text { Gerenciamento Eletrônico de Documentos } \\ \text { GISA } & \text { Gestão Integrada de Sistemas de Arquivo } \\ \text { H/h } & \text { Homem/hora } \\ \text { IPEA } & \text { Instituto de Pesquisas Econômicas Aplicadas } \\ \text { ISO } & \text { International Organization for Standardization } \\ \text { OHSAS } & \text { Occupational Health and Safety Assessment Series } \\ \text { P\&D } & \text { Pesquisa e Desenvolvimento } \\ \text { PDMS } & \text { Plant Design Management System } \\ \text { PDS } & \text { Plant Design System } \\ \text { PINTEC } & \text { Pesquisa de Inovação Tecnológica } \\ \text { PO } & \text { Pessoal Ocupado } \\ \text { PTW } & \text { Power Tools for Windows } \\ \text { PROMIMP } & \text { Programa de Mobilização da Indústria Nacional de Petróleo } \\ \text { QSMS } & \text { Qualidade, Segurança, Meio Ambiente e Saúde } \\ \text { RAIS } & \text { Relação Anual de Informações Sociais } \\ \text { REGAP } & \text { Refinaria Gabriel Passos } \\ \text { REPLAN } & \text { Refinaria de Paulínia } \\ \text { RNEST } & \text { Refinaria do Nordeste } \\ \text { ROP } & \text { Relatório de Ocorrência de Projetos } \\ \text { SMS } & \text { Saúde, Meio-Ambiente e Segurança } \\ \text { STI } & \text { Science, Technology and Innovation } \\ \text { TI } & \text { Tecnologia da Informação } \\ & \end{array}$




\section{SUMÁRIO}

1 INTRODUÇÃO

20 TEMA E SUA JUSTIFICATIVA

2.1 O SETOR DE SERVIÇOS DE ENGENHARIA NO BRASIL .............................. 4

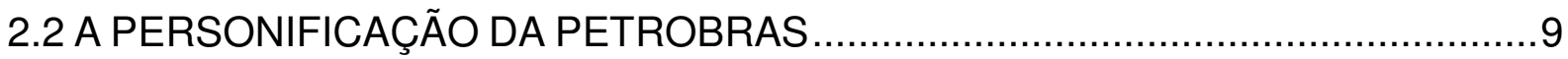

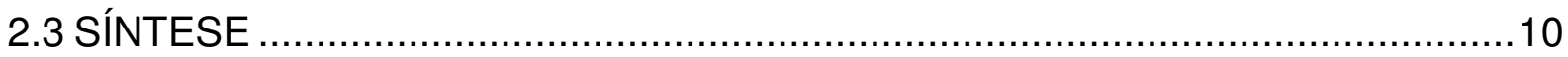

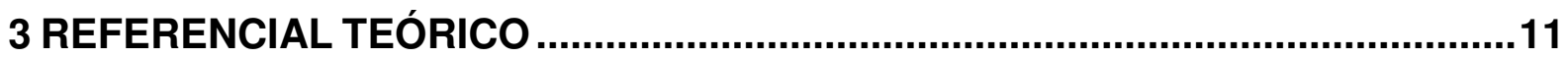

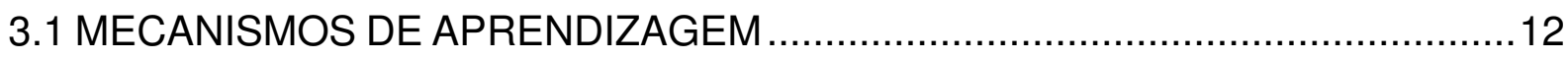

3.1.1 ACÚMULO DE EXPERIÊNCIAS: APRENDIZAGEM ......................................12

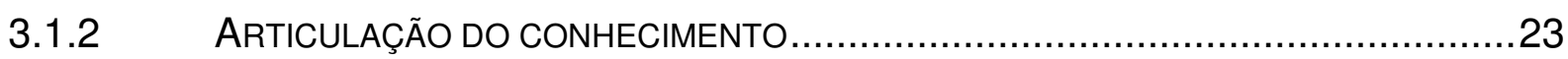

3.1.3 CODIFICAÇÃO DO CONHECIMENTO: ROTINAS ..........................................

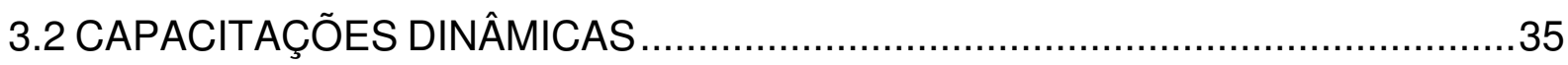

3.3 INDICADORES DE EVOLUÇÃO DA EMPRESA ….......................................39

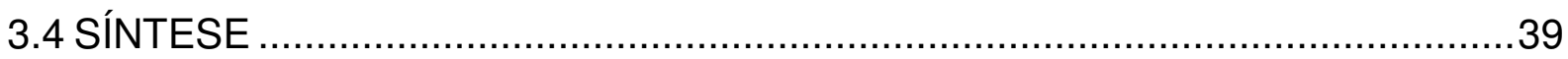

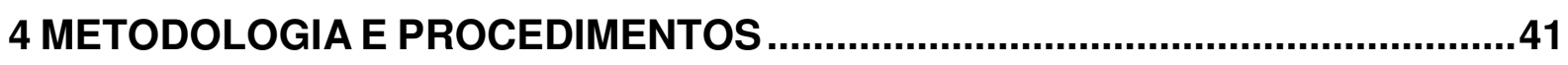

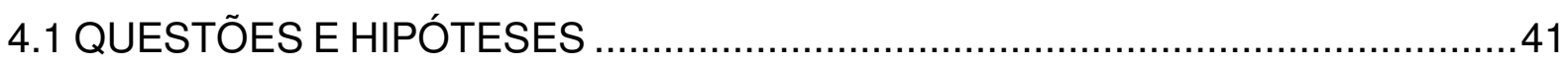

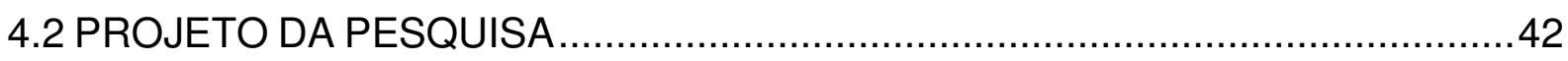

4.2.1 DEFINIÇÃO DA ESTRATÉGIA DE PESQUISA ………................................ 44

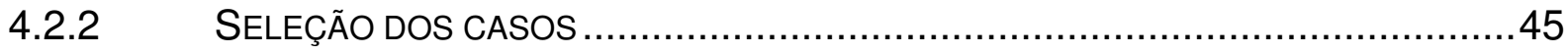

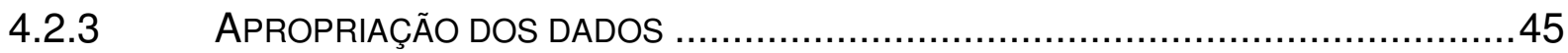

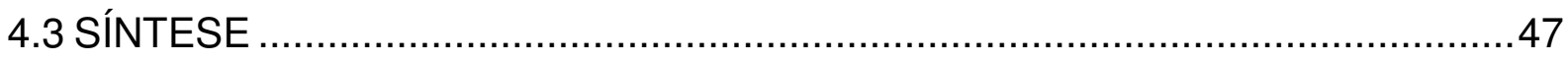

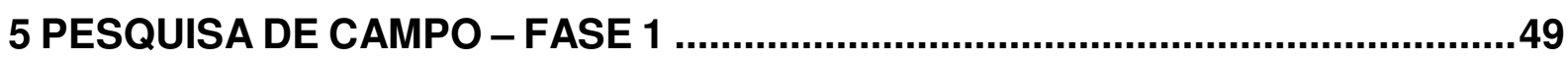

5.1 ESTUDOS DE CASO FASE 1: RELAÇÃO PETROBRAS VERSUS EMPRESAS DE

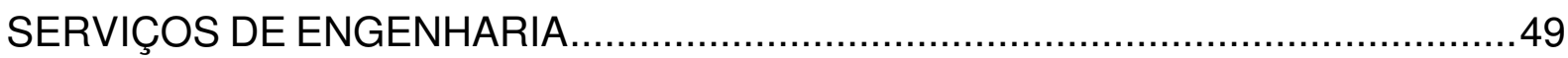

5.1.1 FATOR: INÍCIO DA RELAÇÃO COM A PETROBRAS ....................................51

5.1.2 FATOR: EXIGÊNCIAS CONTRATUAIS ..................................................

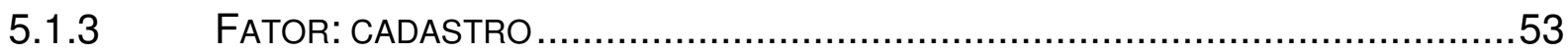

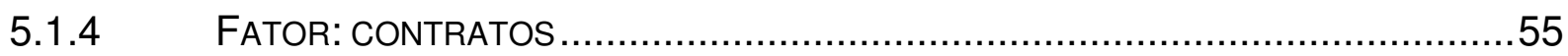

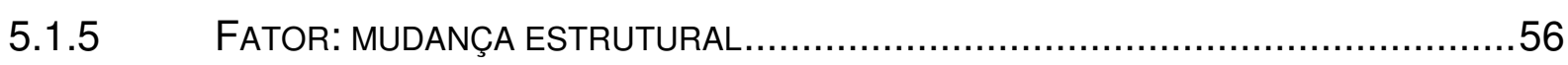

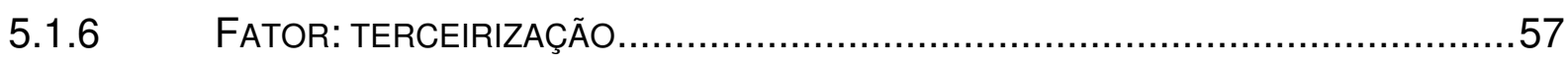

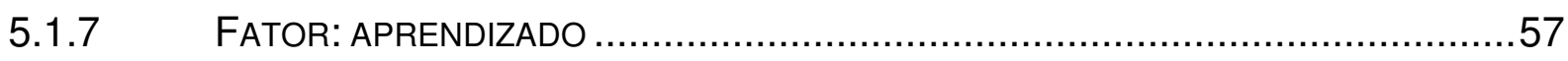

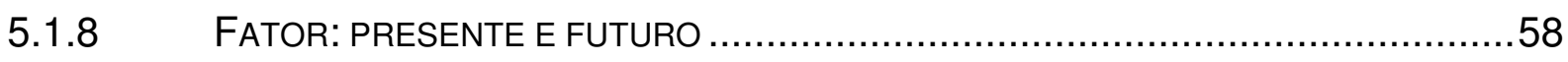

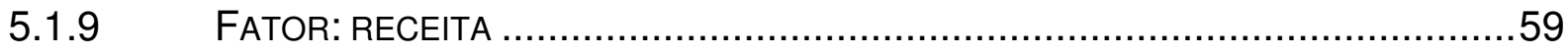


5.2 SÍNTESE .59

6 PESQUISA DE CAMPO - FASE 2 .63

6.1 ESTUDOS DE CASO FASE 2: CRIAÇÃO DAS CAPACITAÇÕES DINÂMICAS NAS EMPRESAS DE SERVIÇOS DE ENGENHARIA ..........................................63

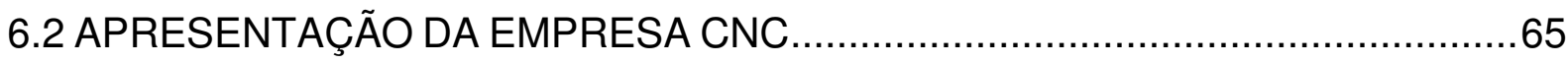

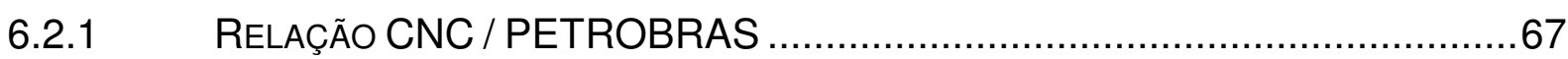

6.2.2 PROJETO 1 - EXECUÇÃO de USINA TERMELÉTRICA A GÁS .............................71

6.2.3 Projeto 2 - PLANTA PARA CARTEIRA DE GASOLINA ………......................74

6.2.4 PROJETO 3 - FEED PARA UM COMPLEXO PETROQUÍMICO ….........................76

6.2.5 A CRIAÇÃO DE CAPACITAÇÕES DINÂMICAS PELA CNC ................................79

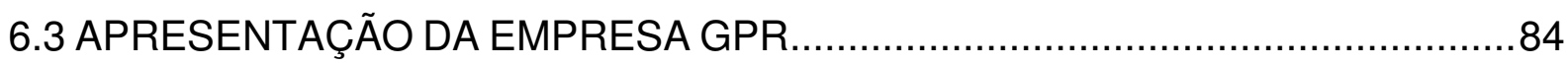

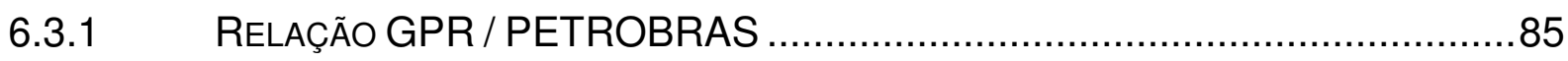

6.3.2 Projeto 1 - Planta de tratamento de GÁS DA REFINARIA .......................89

6.3.3 PROJETO 2 - FEED PARA CARTEIRA DE PROPENO ……...........................

6.3.4 PROJETO 3 - PLANTA PARA CARTEIRA DE GASOLINA ……..........................95

6.3.5 A CRIAÇÃO DE CAPACITAÇÕES DINÂMICAS PELA GPR .................................96

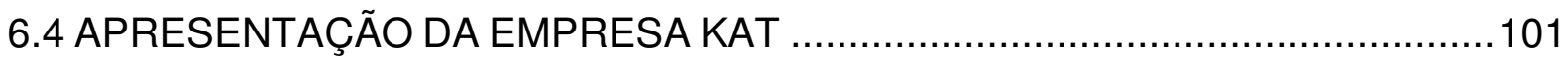

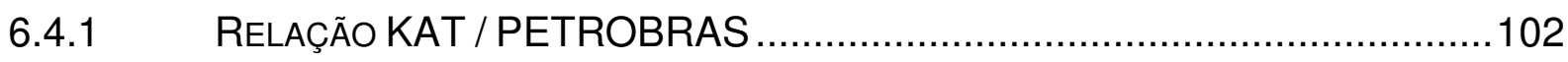

6.4.2 ProJeto 1 - Planta PARA CARTEIRA DE Gasolina ..................................105

6.4.3 PROJETO 2 - FEED PARA CARTEIRA DE DIESEL …...............................108

6.4.4 Projeto 3 - PLANTA PARA CARTEIRA DE ENXOFRE ..................................110

6.4.5 A CRIAÇÃO DE CAPACITAÇÕES DINÂMICAS PELA KAT ...............................112

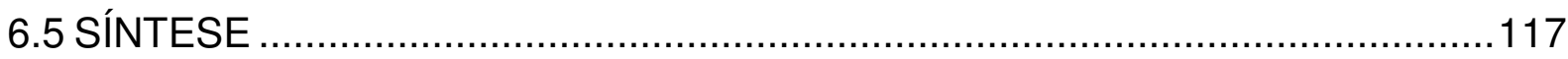

7 RESULTADOS

8 CONCLUSÕES

8.1 CONFRONTANDO HIPÓTESES E RESULTADOS ........................................122

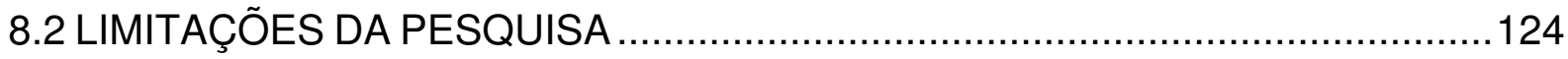

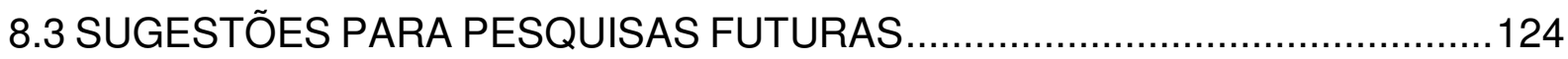

BIBLIOGRAFIA

APÊNDICE 1 - ROTEIRO DE LEVANTAMENTO DE CAMPO (FASE 1) .............................134

APÊNDICE 2 - ROTEIRO DE LEVANTAMENTO DE CAMPO (FASE 2) .............................135 


\section{INTRODUÇÃO}

As empresas de serviços de engenharia são pouco exploradas pela literatura, exceção feita àquelas associadas a grandes construtoras que, eventualmente, aparecem como objeto de estudos de caso.

A proposta desta pesquisa é identificar as características das empresas de serviços de engenharia, fornecedoras da Petrobras, e verificar como constroem suas capacitações dinâmicas, ou seja, capacitações que se alteram conforme o ambiente e que se adaptam, se integram e se organizam de forma adequada (TEECE; PISANO; SHUEN, 1997; WINTER, 2003; EISENHARDT; MARTIN, 2000) para, neste caso, atender às exigências cadastrais e contratuais da Petrobras.

A literatura a respeito das capacitações dinâmicas, de modo geral, está atrelada ao conceito de rotina, que constitui a forma mais importante de estocagem do conhecimento específico da organização. Através da absorção e do acúmulo do conhecimento as rotinas existentes são modificadas, aperfeiçoadas, caracterizando assim uma forma dinâmica da reprodução do conhecimento, capaz de se moldar de acordo com o estado de complexidade do ambiente (ZOLLO; WINTER, 2005).

A personificação da Petrobras neste estudo vem corroborar com dados que mostram que as empresas de serviços de engenharia que atuam no mercado, via contratos com a Petrobras, tem maior crescimento de competências técnicas, gerenciais e organizacionais frente às demais empresas do setor (FREITAS; SALERNO; MISSAWA; 2010).

Visando ampliar a reflexão sobre os conceitos apresentados pela literatura, e para extrapolar os limites que esta por si só poderá sofrer, serão apresentados estudos de múltiplos casos acerca das interações entre as empresas de engenharia e a Petrobras, cuja proposta é trazer o conhecimento prático para uma melhor análise dos resultados e dos objetivos desta dissertação. 
Este trabalho de pesquisa está estruturado da seguinte forma: além do capítulo 1, que trará a parte introdutória, o capítulo 2 apresentará o tema e sua justificativa, além de trazer os principais dados do setor de serviços de engenharia, o que posicionará melhor o leitor acerca do tema objeto desta pesquisa. O capítulo 3 apresenta o referencial teórico, que será composto pelos principais conceitos que norteiam a pesquisa: as capacitações dinâmicas, aprendizagem organizacional, a capacidade absortiva, gestão do conhecimento e as rotinas. Também apresenta as interligações dos conceitos apresentados, ou seja, onde estes se complementam e em que momento devem se convergir para o alcance do objetivo proposto. $O$ capítulo 4 trará o detalhamento do projeto de pesquisa, além das questões e hipóteses que irão direcionar a investigação e as considerações sobre a metodologia adotada para validação, ou não, das hipóteses levantadas. Os capítulos 5 e 6 serão dedicados à explicitação dos estudos de caso, onde serão descritas as empresas participantes, suas características, estruturas e os processos de aprendizagem, obedecendo as fases 1 e 2 , respectivamente, em que ocorreram as pesquisas de campo. O capítulo 7 trará os resultados da análise realizada à luz das discussões conceituais. Finalmente, o capítulo 8 trará as conclusões do trabalho, considerando as proposições apresentadas, as limitações do estudo e algumas sugestões para futuras pesquisas, que visam complementar o estudo a que se propôs esta pesquisa. 


\section{O TEMA E SUA JUSTIFICATIVA}

A ideia de desenvolver esta pesquisa nasceu da participação da autora em um projeto realizado junto ao Ipea (Instituto de Pesquisas Econômicas Aplicadas), cujo objetivo foi avaliar os impactos tecnológicos da Petrobras nas empresas de serviços de engenharia no Brasil.

Os resultados do projeto mostraram que as empresas que atuaram no mercado, via contratos com a Petrobras, tiveram crescimento bem mais acentuado, se comparado as demais empresas do setor. Ao final, concluiu-se que este crescimento é alcançado devido ao papel indutor da Petrobras que, direta ou indiretamente, exige maiores capacitações técnicas e gerenciais de seus fornecedores, o que os lança a um patamar diferenciado no mercado nacional e internacional.

Para auxiliar a compreensão do contexto da pesquisa, tendo em vista as suas particularidades, neste capítulo serão apresentados alguns dados do setor de serviços de engenharia, em comparação à economia nacional e às empresas do setor, que prestam serviços para a Petrobras.

O capítulo trará, também, informações acerca das empresas de serviços de engenharia que tem buscado, constantemente, especializar-se no setor de óleo e gás.

\subsection{O SETOR DE SERVIÇOS DE ENGENHARIA NO BRASIL}

As empresas de serviços de engenharia são pouco exploradas pela literatura, exceção feita àquelas associadas a grandes construtoras que, eventualmente, aparecem como objeto de estudos de caso.

A própria definição do que venha a ser "serviços de engenharia", por sua abrangência, apresenta condicionantes diferentes. Fontoura e Carneiro (2009) 
definem os serviços de engenharia como desenhos e projetos de detalhamento através de documentação técnica a ser utilizada pelos clientes, consorciados ou subfornecedores de materiais e serviços para a execução total da obra. Já a CNAE Classificação Nacional de Atividades Econômicas (2011) os define como serviços de elaboração e gestão de projetos e serviços de inspeção técnica em diferentes áreas da engenharia, como a civil, elétrica, eletrônica, entre outras, bem como a supervisão de obras, o gerenciamento de projetos, vistorias, perícias técnicas, a concepção de maquinaria, processos e instalações industriais. Cabe ainda inserir os serviços de engenharia consultiva como item deste portfólio.

Há também a modalidade de serviços de engenharia epecista (EPC - Engineering, Procurement \& Construction), cuja diferença está no fato de que, nesta modalidade, o escopo da engenharia abrange muito mais do que simplesmente a emissão da documentação de projeto. Ser epecista implica liderança técnica do empreendimento junto ao cliente, aos consorciados e subfornecedores de materiais e serviços. Como tal, inclui atividades de planejamento físico, construção civil, gerenciamento de compras e contratos, montagem eletromecânica e, especialmente, o comissionamento e os testes finais. Implica também em responsabilidade financeira, pois o epecista responde pela obra como um todo (FONTOURA; CARNEIRO, 2009).

No Brasil, existem poucas informações disponíveis sobre o setor de serviços de engenharia, não sendo pesquisado nas principais pesquisas nacionais como, por exemplo, a PINTEC (Pesquisa de Inovação Tecnológica), o que limita uma visão abrangente do setor. A RAIS (Relação Anual de Informações Sociais) do Ministério do Trabalho e Emprego disponibiliza informações sobre características do emprego e do empregado, captando apenas o emprego direto formal, o que novamente limita os dados, visto que grande parte das empresas deste setor trabalha com regime de terceirização de pessoal para grandes projetos e obras.

Para apresentação dos dados do setor de serviços de engenharia, inicialmente, foi utilizada a CNAE, da qual foi analisado somente o código 74.20-9, referente aos Serviços de Arquitetura e Engenharia e de Assessoramento Técnico Especializado. Já os dados utilizados no comparativo entre as empresas com contratos com a Petrobras e as demais do setor foram obtidos através da base de dados da RAIS, 
em conjunto com a base de dados da Petrobras. Dentre os fornecedores cadastrados na Petrobras, foram identificados aqueles cujo código CNAE fosse o acima indicado. A partir daí, utilizando a base de dados "RAIS Empresa", foram levantadas diversas informações sobre as empresas de serviços de engenharia (SALERNO; FREITAS; MISSAWA, 2011).

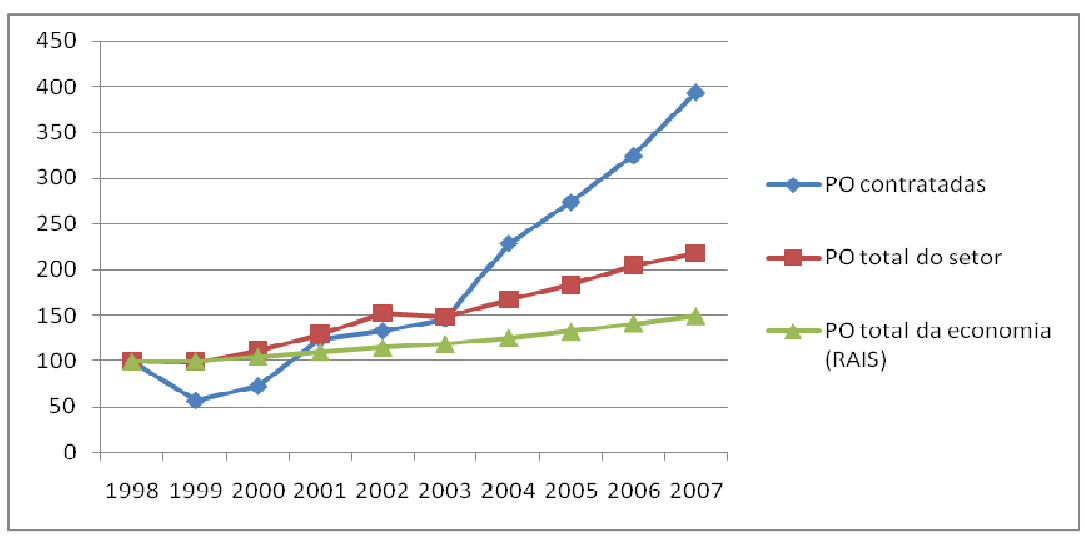

Gráfico 1- Comparação do pessoal ocupado

Fonte: Freitas, Salerno e Missawa (2010)

O gráfico 1 estabelece uma comparação percentual entre o crescimento da economia, do setor e das empresas contratadas do setor. O pessoal ocupado no setor de serviços de engenharia cresceu $118 \%$, bem acima da taxa geral da economia, que foi de $50 \%$. Já as empresas de engenharia com contratos com a Petrobras cresceram 293\% entre 1998 e 2007, crescimento este muito superior ao setor e à economia.

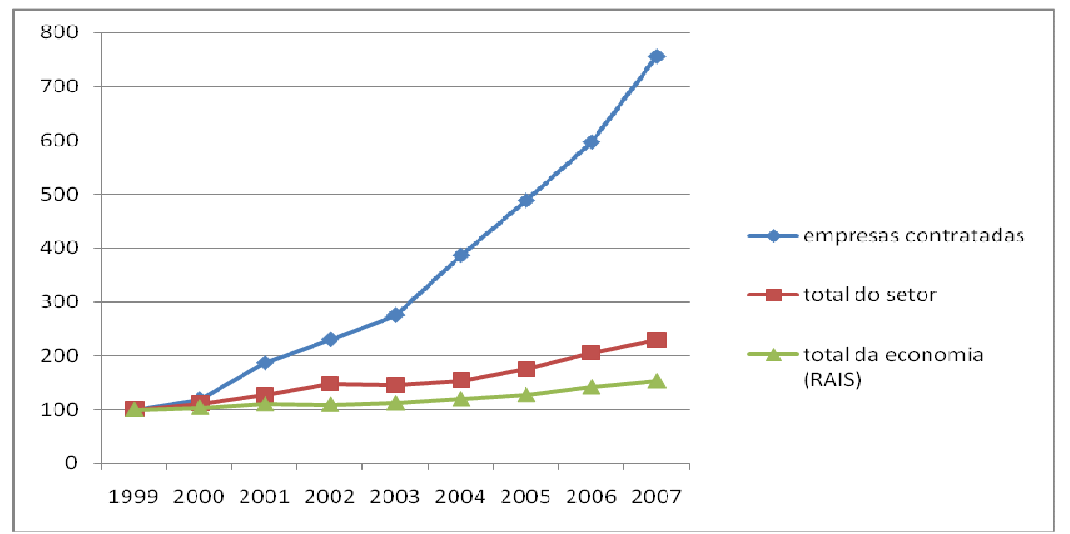

Gráfico 2 - Evolução da massa salarial

Fonte: Freitas, Salerno e Missawa (2010) 
O gráfico 2 compara o crescimento percentual das massas salariais. Partindo-se da base 100 , ele evidencia que o total da economia apresentou crescimento de massa salarial de 54\%. O setor apresentou aumento de 130\%. Já as empresas de engenharia, fornecedoras da Petrobras, apresentaram maior crescimento em dispêndios com salários: $656 \%$.

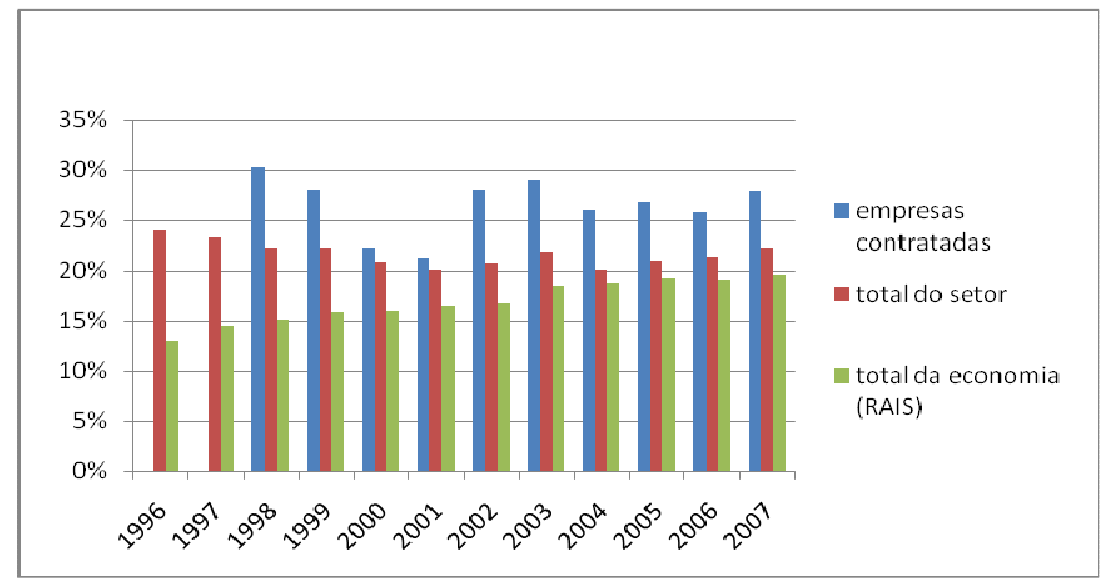

Gráfico 3 - Evolução do pessoal ocupado com $3^{\circ}$ grau Fonte: Freitas, Salerno e Missawa (2010)

O gráfico 3 mostra que a proporção de funcionários com $3^{\circ}$ grau, considerando empregos formais, vem crescendo na economia. No período considerado, o crescimento passou de 13\% (1996) para 20\% (2007). No setor de serviços de engenharia, a proporção oscilou entre $20 \%$ e $24 \%$.

Este fato é esperado, tendo em vista o serviço especializado e que exige maior habilidade dos funcionários, normalmente obtido em curso de nível superior. Já o crescimento das empresas contratadas pela Petrobras, embora tenham apresentado comportamento irregular, oscilaram em torno de $26 \%$, maior do que a economia e maior do que o setor. 


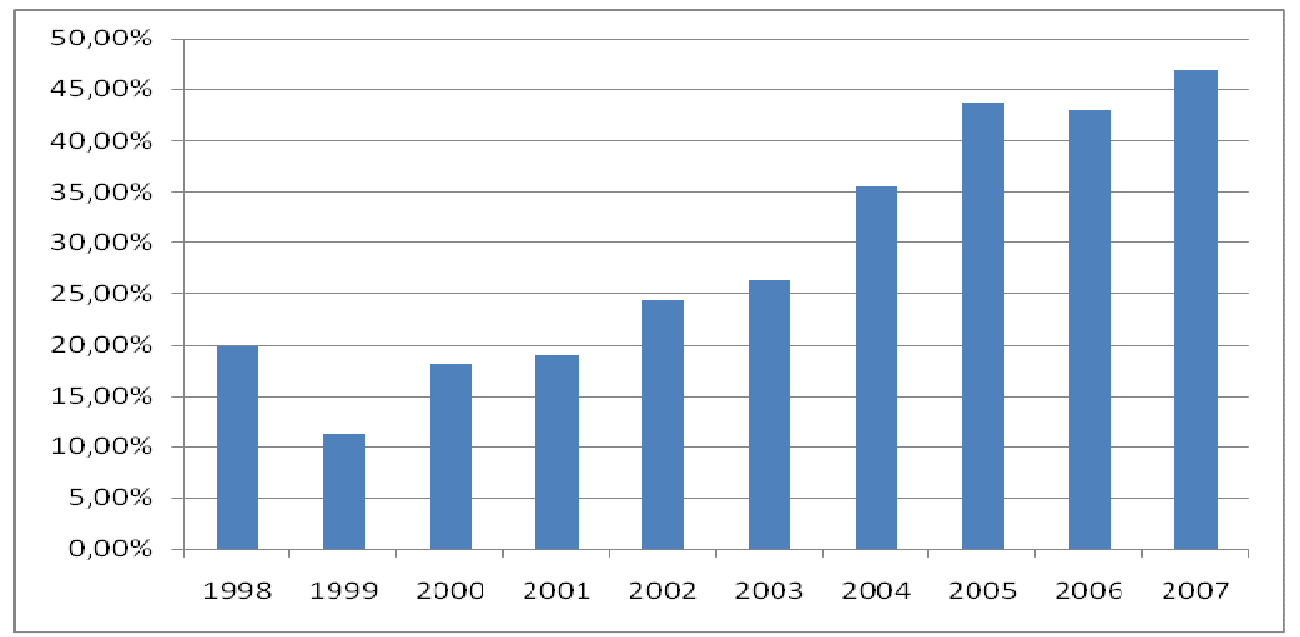

Gráfico 4 - Evolução da proporção de engenheiros nas empresas contratadas Fonte: Freitas, Salerno e Missawa (2010)

O gráfico 4 mostra que a proporção de engenheiros empregados no setor de serviços de engenharia, que trabalham para as empresas contratadas pela Petrobras atingiu 46,87\% ao final do período. O aumento foi de $318 \%$ entre 1999 e 2007. Isso sugere maior conteúdo técnico e maior valor agregado nas empresas, 0 que se relaciona aos contratos e a suas exigências.

Os dados acima nos permitem concluir que as empresas de engenharia contratadas pela Petrobras se destacam tanto em relação à economia em geral quanto ao setor a que pertencem, pois tiveram crescimento muito mais acentuado. No período considerado (1998 a 2007) estas empresas cresceram 209\%, enquanto o setor cresceu $118 \%$ e a economia apenas $50 \%$.

Diante dos resultados apontados no projeto surgiu à ideia de analisar, através de estudos de caso, quais características levam estas empresas a terem crescimento mais acentuado, se comparadas às demais empresas do setor, e ainda, em que momento a Petrobras passa a ter responsabilidade, ou papel indutivo, neste crescimento. 


\subsection{A PERSONIFICAÇÃO DA PETROBRAS}

De acordo com a revista Forbes, a Petrobras foi apontada como a $8^{\underline{a}}$ maior empresa do mundo em 2011, sendo a única empresa latino-americana no ranking das dez maiores, além de figurar como detentora do 5ำ maior valor de mercado.

A descoberta da camada do pré-sal fez crescer o negócio do petróleo, sobretudo na exploração, produção e refino, o que consome muitos serviços especializados, gerando atividades, emprego e conhecimento específico nas empresas de serviços de engenharia. Os dados do sistema de cadastro da Petrobras mostram que nos últimos anos houve um crescimento acentuado no número de empresas cadastradas como fornecedoras de serviços de engenharia, o que corrobora com a afirmação de que o setor está em aquecimento.

Com os desafios do pré-sal, a tendência é que as empresas de serviços de engenharia sejam desafiadas a desenvolver maiores capacitações e prover soluções técnicas inovadoras para a Petrobras, o que poderá lança-las a um patamar diferenciado, inclusive no mercado internacional.

As licitações da Petrobras são muito detalhadas. O nível de exigência vai desde a especificação do software a ser utilizado na confecção do projeto, até a determinação de metragem e recursos para alocação de funcionários da Petrobras na empresa de serviços de engenharia durante a execução da obra. Diante de tantas exigências, ser ganhador de contratos com a Petrobras pré-estabelece normas de conduta profissional, atualizações técnicas frequentes, responsabilidade e compromissos contratuais e, muitas vezes, uma mudança na estrutura e na própria cultura empresarial.

A personificação da Petrobras neste estudo vem corroborar com dados que mostram que as empresas de serviços de engenharia que atuam no mercado, via contratos com a Petrobras, tem maior crescimento de competências técnicas, gerenciais e organizacionais frente às demais empresas do setor (FREITAS; SALERNO; MISSAWA; 2010). 
Tem-se então um breve cenário de como a Petrobras pode interferir nas empresas com a qual mantém relações contratuais. É nesse ponto que o presente texto visa contribuir, através de duas fontes: uma revisão bibliográfica acerca da criação de capacitações dinâmicas, e a apresentação de estudos de múltiplos casos nas empresas de serviços de engenharia, considerando o papel indutor da Petrobras.

\subsection{SÍNTESE}

O primeiro quadro resume os fatores que originaram esta pesquisa e a opção pela personificação da Petrobras.

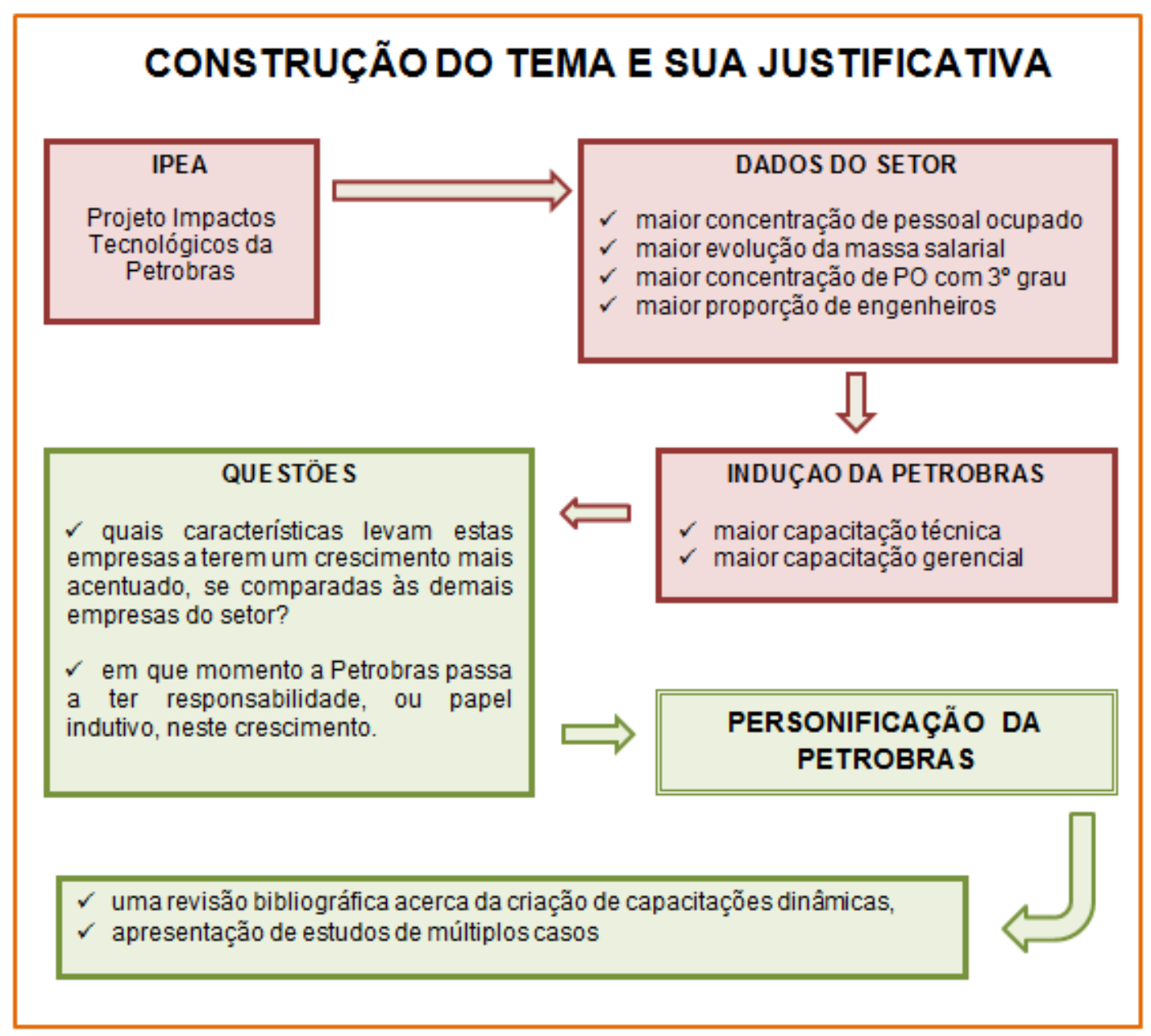

Quadro 1 - Síntese da construção do tema e sua justificativa.

Fonte: Autora 


\section{REFERENCIAL TEÓRICO}

Para desenvolver este referencial, o primeiro conceito que se buscou entender foi o das Capacitações Dinâmicas onde, a partir do artigo "Understanding Dynamic Capabilities" (WINTER, 2003), aplicou-se a técnica da "bola de neve" (PATTON, 2002) que consiste em identificar artigos contidos nas referências pesquisadas, visando alcançar o conhecimento que se deseja obter.

A abordagem deste referencial teórico vai além do conceito puro das capacitações dinâmicas. Os próximos tópicos serão dedicados á explicitar as diferentes vertentes deste conceito chave, bem como apontar os conceitos que figuram como base para a criação das capacitações na empresa, como a aprendizagem, o conhecimento e suas relações vistas sob a ótica de diferentes autores.

Para tanto, este referencial tem como objetivo proceder com a investigação dos mecanismos de aprendizagem pelos quais as organizações criam suas capacitações dinâmicas. O modelo teórico a ser utilizado propõe a análise do (1) acúmulo de experiências, (2) da articulação do conhecimento e (3) da codificação do conhecimento (ZOLLO; WINTER, 2002).

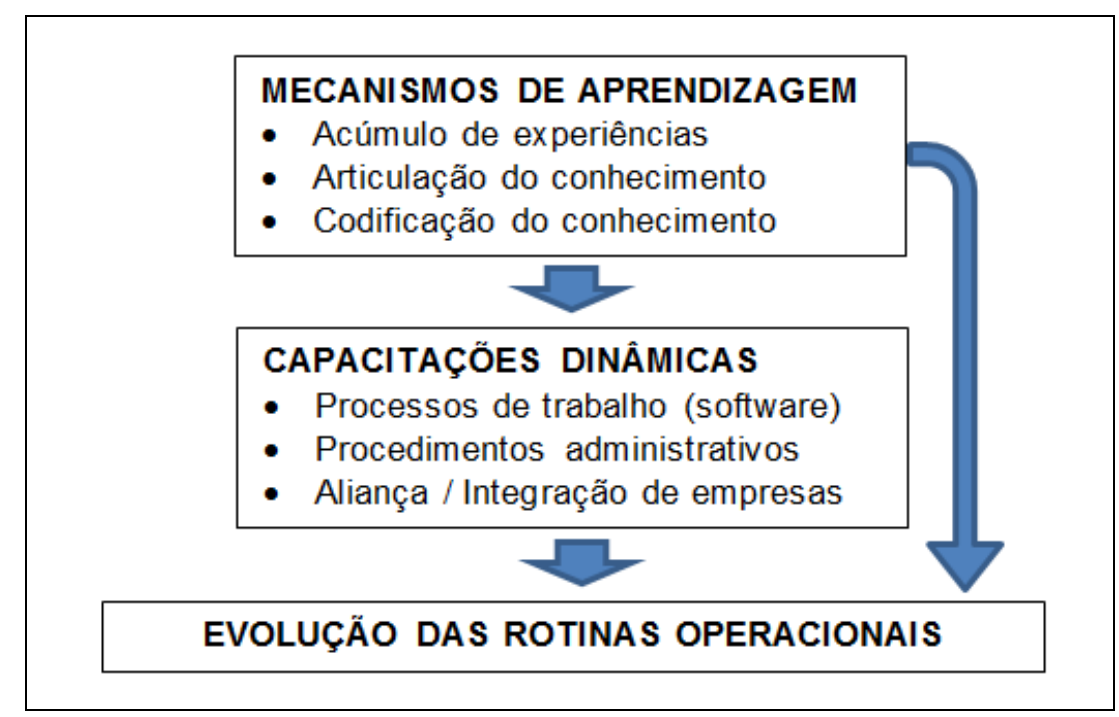

Quadro 2 - Aprendizagem, capacitações dinâmicas, e rotinas operacionais Fonte: Adaptado de Zollo e Winter (2002) 


\subsection{MECANISMOS DE APRENDIZAGEM}

Os mecanismos de aprendizagem fornecem a base para o desenvolvimento das capacidades empresariais (EISENHARDT; MARTIN, 2000). Segundo Zollo e Winter (2002), assim que criadas, as empresas desenvolvem certo grau de aprendizagem através de comportamentos constituídos do acúmulo de experiências e da articulação do conhecimento adquirido. A interação destes fenômenos, e sua codificação, permitem às empresas criar ou aprimorar suas capacitações por meio de rotinas.

A proposta aqui é destacar quais mecanismos podem estar envolvidos na criação e na evolução das capacitações dinâmicas na empresa, bem como analisar como as empresas podem se beneficiar destes mecanismos para avaliar suas ações em função dos resultados que desejam obter.

\subsubsection{Acúmulo de experiências: aprendizagem}

Zollo e Winter (2002), através dos mecanismos de aprendizagem, procuram fornecer uma base clara para a análise dos processos de aprendizagem que formam as rotinas e as capacitações dinâmicas.

O conhecimento e as formas de aprendizagem tem se tornado elementos essenciais no contexto das capacitações, pois influenciam diretamente o desempenho da empresa. A base conceitual que sustenta essa capacidade é chamada de "aprendizagem organizacional" (SENGE, 2009).

Durante muitos anos, o estudo da aprendizagem organizacional reuniu conceitos, atividades e práticas voltadas para o ambiente interno das empresas. No início da década de 90 as publicações já mostravam que o ambiente externo merecia igual importância e passaram, então, a abordá-lo em grande parte dos estudos (MARCH, 1991). 
Diante do contexto econômico atual, onde há grande concorrência entre as empresas na busca por alguma vantagem competitiva, o sucesso nos mercados depende cada vez mais do aprendizado (ARGYRIS, 2006) e poucas empresas são capazes de criar, sozinhas, o aprendizado organizacional, necessitando interagir com outras empresas para fazê-lo (SENGE, 2009). Porém, esta interatividade deve ser gerenciada de modo que a aprendizagem seja conduzida à criação de novas capacitações, que possam conferir a vantagem competitiva ambicionada pelas empresas.

Easterby-Smith, et al. (2004) elencaram, a contar do ano de 1978, as sete principais contribuições acadêmicas para o estudo da aprendizagem.

\begin{tabular}{|c|c|c|c|}
\hline & DEFINIÇĀO & NOVA TEORIA & $\begin{array}{c}\text { AUTORES } \\
\text { REPRESENTATIVOS }\end{array}$ \\
\hline 1 & $\begin{array}{l}\text { Aprendizagem single e } \\
\text { doble-loop }\end{array}$ & $\begin{array}{l}\text { Encapsulamento de ideias } \\
\text { existentes }\end{array}$ & Argyris e Schon (1978) \\
\hline 2 & $\begin{array}{l}\text { Teoria adotada e teoria } \\
\text { praticada }\end{array}$ & $\begin{array}{l}\text { Baseou-se na teoria } \\
\text { psicanalítica }\end{array}$ & Argyris e Schon (1978) \\
\hline 3 & Desaprender & Contra ideias intuitivas & Hedberg (1981) \\
\hline 4 & $\begin{array}{l}\text { Organizações de } \\
\text { aprendizagem }\end{array}$ & $\begin{array}{l}\text { Baseou-se no sistema de } \\
\text { trabalho dinâmico (Forrester) e } \\
\text { nas rotinas (Argyris) }\end{array}$ & Senge (1990) \\
\hline 5 & Perspectiva sociocultural & Antropologia social & $\begin{array}{l}\text { Brown e Duguid (1991) } \\
\text { Cook e Yanow (1993) }\end{array}$ \\
\hline 6 & $\begin{array}{l}\text { Aprendizagem através das } \\
\text { fronteiras }\end{array}$ & Adiciona teoria cultural & $\begin{array}{l}\text { Inkpen e Crossan (1995) } \\
\text { Lyles e Salk (1996) } \\
\text { Inkpen (2000) }\end{array}$ \\
\hline 7 & $\begin{array}{l}\text { Conhecimento, } \\
\text { aprendizagem e } \\
\text { competitividade }\end{array}$ & $\begin{array}{l}\text { Adiciona estratégia e visão } \\
\text { baseada em recursos }\end{array}$ & $\begin{array}{l}\text { Cohen e Levinthal (1990) } \\
\text { Hippel(1994) } \\
\text { Teece et al. (1997) } \\
\text { Eisenhardt e Martin (2000) } \\
\text { Zollo e Winter (2002) }\end{array}$ \\
\hline
\end{tabular}

Quadro 3 - Natureza das contribuições no campo da aprendizagem organizacional

Fonte: Adaptado de Easterby-Smith et al. (2004)

O crescente reconhecimento da importância do processo de aprendizagem e de suas implicações no ambiente de trabalho contribuiu para a consolidação de um 
campo de estudo bastante vasto sobre a aprendizagem nas organizações (BASTOS; GONDIM; LOIOLA, 2004). Porém, este campo conceitual tem sido caracterizado por duas vertentes: a da aprendizagem organizacional e a das organizações que aprendem.

Estamos tratando, portanto, de dois conceitos distintos que, embora apresentem convergências no que tange a sistematização dos métodos de análise da aprendizagem, apresentam diferentes perspectivas em suas abordagens.

\begin{tabular}{|c|c|c|}
\hline & $\begin{array}{l}\text { APRENDIZAGEM } \\
\text { ORGANIZACIONAL }\end{array}$ & $\begin{array}{c}\text { ORGANIZAÇŌES QUE } \\
\text { APRENDEM }\end{array}$ \\
\hline Principais teóricos & Pesquisadores acadêmicos & $\begin{array}{l}\text { Consultores e pesquisadores } \\
\text { orientados à transformação } \\
\text { organizacional. }\end{array}$ \\
\hline Base para construção teórica & $\begin{array}{l}\text { Teorização com base em } \\
\text { investigação empírica }\end{array}$ & $\begin{array}{l}\text { Teorização com base em } \\
\text { experiências práticas de } \\
\text { sucesso }\end{array}$ \\
\hline Foco de análise & $\begin{array}{l}\text { Processo: como as } \\
\text { organizações estão } \\
\text { aprendendo }\end{array}$ & $\begin{array}{l}\text { Atributo: o que as } \\
\text { organizações devem fazer } \\
\text { para aprender }\end{array}$ \\
\hline Orientação da literatura & Descritiva, crítica e analítica & Prescritiva e normativa \\
\hline Orientação normativa & $\begin{array}{l}\text { Preocupada também em } \\
\text { encontrar respostas acerca das } \\
\text { possibilidades concretas das } \\
\text { organizações aprenderem }\end{array}$ & $\begin{array}{l}\text { Apoiada na ausência de } \\
\text { questionamento das } \\
\text { possibilidades das } \\
\text { organizações aprenderem }\end{array}$ \\
\hline
\end{tabular}

Quadro 4 - Aprendizagem organizacional versus organizações que aprendem

Fonte: Bastos e Loiola (2004)

De acordo com Tsang ${ }^{1}$ (1997 apud Bastos; Gondim; Loiola, 2004), a primeira vertente - aprendizagem organizacional - interessa-se pela descrição de como a organização aprende, ou seja, focaliza as habilidades, os processos de construção e utilização do conhecimento que favorecerão a reflexão sobre as possibilidades concretas de ocorrer aprendizagem nesse contexto. A segunda vertente organizações que aprendem - tem foco na ação e no ajuste de ferramentas

\footnotetext{
${ }^{1}$ TSANG, E. W. K. Organizational learning and the learning organizational: a dichotomy between descriptive and prescriptive research. Human Relations, New York, v.50, n.1, p.73-89, 1997.
} 
metodológicas específicas para o diagnóstico e para a avaliação da qualidade dos processos de aprendizagem, os quais servirão de base para a normalização e a prescrição daquilo que uma organização deve fazer para aprender.

Easterby-Smith, Burgoyne e Araujo (1999), Bastos et al. (2004), entre outros, apontam que dentro de cada uma dessas perspectivas, há tensões, limitações e potenciais de análise. Na visão de Bastos et al. (2004) ambas perspectivas são importantes, pois ensejam, de um lado, a explicação / compreensão do fenômeno e, de outro, oferecem ferramentas para a ação e a prática organizacional. Diante desta visão, cabe ressaltar que o presente estudo utilizará ambos os conceitos.

O estudo da aprendizagem no contexto das organizações tem atraído atenção de vários pesquisadores, mas é preciso cuidado já que, além das perspectivas apontadas acima, há conceitos com aspectos de abordagem bastante diferentes. Uma pequena amostra desta diversidade pode ser vista no quadro 5, onde são apresentados alguns conceitos. 


\begin{tabular}{|c|c|c|c|}
\hline DEFINIÇÃO & $\begin{array}{l}\text { NÍVEL DE } \\
\text { ANÁLISE }\end{array}$ & $\begin{array}{c}\text { NATUREZA DO } \\
\text { PROCESSO/PRODUTO }\end{array}$ & $\begin{array}{c}\text { AUTORES } \\
\text { REPRESENTATIVOS }\end{array}$ \\
\hline $\begin{array}{l}\text { “... crescimento de insights e } \\
\text { de reestruturações bem } \\
\text { sucedidas de problemas } \\
\text { organizacionais, provenientes } \\
\text { de indivíduos que exercem } \\
\text { papéis decisivos na estrutura } \\
\text { e nos resultados da } \\
\text { organização.” }\end{array}$ & Individual & $\begin{array}{l}\text { Estrutural e de } \\
\text { desempenho }\end{array}$ & Simon (1970, p.125) \\
\hline $\begin{array}{l}\text { “... aquisição, sustentação e } \\
\text { mudança de significados } \\
\text { intersubjetivos através da } \\
\text { expressão e transmissão de } \\
\text { ações coletivas de grupo.” }\end{array}$ & Grupal & Cultural & $\begin{array}{l}\text { Cook e Yanow (1996, } \\
\text { p.384) }\end{array}$ \\
\hline $\begin{array}{l}\text { “... processo pelo qual a base } \\
\text { do conhecimento } \\
\text { organizacional é construída e } \\
\text { desenvolvida (...).” }\end{array}$ & Organizacional & Cognitivo & $\begin{array}{l}\text { Shrivastava (1983, } \\
\text { p.15) }\end{array}$ \\
\hline $\begin{array}{l}\text { “... codificação de } \\
\text { interferências oriundas da } \\
\text { história da organização que } \\
\text { se manifestam por meio das } \\
\text { rotinas que guiam o } \\
\text { comportamento.” }\end{array}$ & Organizacional & $\begin{array}{l}\text { Cognitivo / } \\
\text { Comportamental }\end{array}$ & $\begin{array}{l}\text { Levitt e March (1988, } \\
\text { p.320, apud Tsang, } \\
\text { 1997, p.76) }\end{array}$ \\
\hline $\begin{array}{l}\text { “... a capacidade, conjunto de } \\
\text { processos internos que } \\
\text { mantém ou melhoram o } \\
\text { desempenho baseado na } \\
\text { experiência, cuja } \\
\text { operacionalização envolve a } \\
\text { aquisiçãã, a disseminação e a } \\
\text { utilização do conhecimento.” }\end{array}$ & Organizacional & $\begin{array}{l}\text { Cognitivo / } \\
\text { Comportamental }\end{array}$ & $\begin{array}{l}\text { DiBella, Nevis e } \\
\text { Gould (1996, p.365) }\end{array}$ \\
\hline 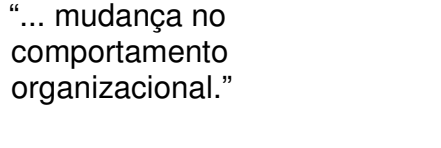 & Organizacional & Comportamental & $\begin{array}{l}\text { Swiering e } \\
\text { Wierdsman (1992, } \\
\text { p.33, apud Tsang, } \\
\text { 1997, p.76) }\end{array}$ \\
\hline
\end{tabular}

Quadro 5 - Definições de aprendizagem organizacional

Fonte: Adaptado de Bastos, Gondim, Loiola (2004)

Tal discrepância foi discutida por Law (2009) e apenas um consenso foi identificado: "a aprendizagem organizacional baseia-se no processo de aprendizagem dos indivíduos na organização". Esta afirmação nos remete a constatação, também observada pela autora, de que, como os indivíduos, as organizações também se diferenciam em alguns aspectos, logo a aprendizagem organizacional não pode ser conceituada porque não há singularidade nas organizações. 
Esse dilema quanto à aprendizagem não é recente, nem tão pouco está perto de ser resolvido. Ideias sobre quem deve aprender, o que pode ser aprendido ou quão rápido pode ser aprendido, são, sem dúvida, influenciadas por experiências anteriores da organização. Este efeito é mais forte quando a nova capacidade se assemelha a algo que a organização já tentou aprender anteriormente. No entanto, prover uma resposta correta é tarefa difícil (WINTER, 2000).

Easterby-Smith et al. (2004) acreditam que vários pesquisadores continuarão a confrontar-se diante do desafio de capturar os diferentes aspectos que constituem a complexidade da aprendizagem organizacional.

Considerando que as organizações aprendem de forma diferente, então parecem existir evidências fortes de que diferenças relativas ao contexto - pessoas, grupos, setor e local de atuação - são condicionantes que exercem impacto sobre a vivência de aprendizagem de cada organização (BASTOS et al. 2004).

\subsubsection{Formas e processos de aprendizagem}

Quanto aos processos pelos quais as empresas criam o aprendizado, há diferentes mecanismos dispostos na literatura.

Garvin (1993) acredita que toda empresa deve ter um compromisso com a aprendizagem, afinal, sem ela não há como aprender algo novo. Segundo o autor, a ausência de um compromisso com a aprendizagem nas empresas leva-as a incorrer no erro de repetir velhas práticas. Já a forma de aprendizagem eficaz, na visão do autor, é o que aborda o que chama de "3M's" - Meaning, Management, and Measurement (Significado, Gestão e Mensuração). Sem a compreensão dos 3M's, dificilmente haverá progresso em uma empresa.

Garvin, Edmondson e Gino (2008) vão além e defendem a ideia de que é necessário que exista um ambiente de apoio à aprendizagem, com processos específicos e cuja liderança reforce o aprendizado em todo o ambiente organizacional. 
Para Levinthal e March (1993), as organizações utilizam dois mecanismos principais para facilitar a aprendizagem através da experiência. A primeira é a 'simplificação', onde os processos de aprendizagem buscam simplificar a experiência para minimizar as interações e restringir os efeitos da vizinhança espacial e temporal das ações. A segunda é a 'especialização', onde processos de aprendizagem tendem a concentrar atenção e competência restrita.

Jensen et al. (2007) apresentam dois modos de aprendizagem: um modo baseia-se na produção e utilização de codificação científica e conhecimentos técnicos, nomeando-o como Ciência, a Tecnologia e a Inovação (STI - do inglês Science, Technology and Innovation); o outro baseia-se na experiência e é o modo de aprendizagem baseado em Fazer, Usar e Interagir (DUI - do inglês Doing, Using and Interacting). Os dois modos apresentados por Jensen relacionam-se com diferentes tipos de conhecimento: explícito (ou codificado) e tácito.

Uma forma de tornar o conhecimento explícito é escrevê-lo para que seja transferido e absorvido por aqueles que podem ler e compreender a linguagem específica. Porém, absorver esse conhecimento raramente é automático e, muitas vezes, requer habilidade e competência dos membros receptores, que precisam ter algum conhecimento prévio sobre o assunto (JENSEN et al., 2007).

Easterby-Smith (1997), por exemplo, acredita ser a aprendizagem um processo organizacional de intercâmbio recíproco entre indivíduos, grupos e outras entidades organizacionais. Para Easterby-Smith, Crossan e Nicolini (2000) a unidade de análise da aprendizagem organizacional é o indivíduo e, portanto, nele se concentra a aprendizagem organizacional, ainda que seja possível deter parte dela em forma de sistemas, relatórios, formulários, etc.

Já na visão de Senge (2009) e West (1994), a aprendizagem individual não garante a aprendizagem organizacional, entretanto, sem ela a aprendizagem organizacional não ocorre. 
Indo além do conceito de aprendizagem organizacional, Mintzberg (1987) acredita que a estratégia que define a prática de aprendizagem emerge de pequenos passos, na medida em que a empresa se adapta ou aprende. Segundo Mintzberg, Ahlstrand e Lampel (2000), as estratégias de aprendizagem assumem duas formas: 'deliberadas', quando planejadas, formuladas por líderes e sustentadas por mecanismos de controle que permitam sua implementação sem riscos; ou 'emergentes', quando impostas pelo ambiente externo, normalmente de forma inesperada e em resposta a uma situação de mudança.

As estratégias puramente deliberadas bloqueiam a aprendizagem, uma vez que elas já foram formuladas. Já a estratégia emergente, embora apresente maior dificuldade de controle, permite a aprendizagem ao reconhecer no indivíduo a possibilidade da identificação de situações isoladas que, após analisadas e selecionadas, podem transformar-se em estratégias emergentes (MINTZBERG; AHLSTRAND; LAMPEL, 2000).

Considerando que muitas organizações operam em ambientes imprevisíveis, nenhum dos enfoques é sensato se trabalhados no limite, sendo ideal que as empresas mantenham certa flexibilidade (MINTZBERG, 1987).

Com base nas ideias de Scarbrough et al. (2004), as empresas de serviços de engenharia poderão ser analisadas também no contexto da aprendizagem através de projetos, "(...) ainda que esta análise requer uma abordagem mais ampla, capaz de identificar as ligações entre aprendizagem intra-projeto e a transferência da aprendizagem para a organização". Para o autor, pode haver uma significativa quantidade de aprendizagem em um projeto, embora, normalmente, encontra-se dificuldade para capturar e compartilhar o conhecimento entre os projetos, ou entre um projeto e a organização.

Os autores destacam três dimensões da aprendizagem baseada em projetos:

a) Conhecimento com base na prática: a prática pode ser definida como uma ação do indivíduo a partir de um contexto previamente determinado e a aprendizagem emerge das respostas improvisadas que os indivíduos dão á 
esta ação. A divisão das práticas dentro das organizações, como a especialização funcional, é vista como vantajosa para o acúmulo e o armazenamento da aprendizagem ao longo do tempo;

b) Projeto de autonomia: a divisão das práticas influencia a autonomia dos projetos. O projeto de autonomia é vantajoso para a aprendizagem, pois permite o desenvolvimento de práticas completamente diferentes das práticas organizacionais. Uma das implicações desta autonomia é destacar a importância de uma divisão da prática na definição de aprendizagem baseada em projetos.

c) Integração do conhecimento: envolve a superação de barreiras ao fluxo e a transferência de conhecimento resultantes das divisões das práticas préexistentes entre os membros da equipe. Essas barreiras são vistas como 'fronteiras do conhecimento' e podem assumir três formas: a 'sintática' (linguagem), onde o fluxo de conhecimento é inibido pela falta de sintaxe comum entre os indivíduos ou equipes; a 'semântica' (significado), onde os grupos são incapazes de compartilhar conhecimentos porque trazem interpretações diferentes a ele; e a 'pragmática' (prática), onde o fluxo de conhecimento é limitado por diferenças investidas nas práticas e interesses entre os grupos.

Segundo Scarbrough et al. (2004), é através do trabalho que o conhecimento e a aprendizagem podem ser gerados, quer através da 'tradução' (onde os atores desenvolvem uma linguagem comum a fim de entender as partes), quer através da 'transformação' (onde os envolvidos na solução de um problema comum criam novos entendimentos). Além disso, as tarefas de projeto geram oportunidades significativas de aprendizagem, na medida em que os projetos se diferenciam e criam novas práticas.

As organizações capacitadas a aprender são vistas como organizações onde pessoas ampliam constantemente a capacidade de criar resultados desejáveis, onde se fomentam novos padrões de pensamento (SENGE, 2009) e, nesse contexto, Azmi (2008) vai além e defende a ideia de que a empresa deve estar apta a 
desaprender algo para reaprender de forma mais eficaz. Tal prática decorre do modelo LUR - learn-unlearn-relearn (aprender, desaprender, reaprender) - que implica numa gestão voltada à flexibilidade e agilidade nas manobras operacionais, de forma que a empresa se antecipe às oportunidades do mercado frente aos seus concorrentes.

Inúmeras são as formas de aprendizagem que as empresas podem admitir. $\mathrm{Na}$ última década, o estudo da aprendizagem através da participação interorganizacional ganhou destaque na literatura, dando ênfase na formação de alianças estratégicas, parcerias e colaboração entre organizações. É o que Winkelen (2010) chama de 'Aprendizado Colaborativo'. Trata-se de uma estratégia competitiva que visa o aumento da competência das empresas através da transição da eficiência isolada para a eficiência coletiva (FLEURY; FLEURY, 2003).

No caso de fusões, aquisições ou parcerias, Wilkelen (2010) ainda destaca que as causas podem ser as mais variadas, porém, é comum que um dos motivos esteja presente: resolver problemas operacionais imediatos ou construir capacitações para o futuro. Independente dos motivos, a qualidade da relação entre as organizações é um aspecto necessário para a realização da aprendizagem colaborativa. A busca pelo sucesso das alianças inter-organizacionais envolve a criação de um ambiente colaborativo, a construção de relações de confiança entre os indivíduos e, então, cria-se uma identidade partilhada nas empresas (WINKELEN, 2010).

Embora os conceitos sobre a aprendizagem organizacional sofram algumas diferenciações entre os autores citados, é consenso dizer que o conhecimento está contido em todas as práticas de aprendizagem, sejam elas tácitas ou explícitas deliberadas ou emergentes, ou qualquer outro processo de aprendizagem apresentado.

O quadro 6 trará um breve resumo das formas, processos e estratégias de aprendizagem vistas neste tópico. 


\begin{tabular}{|c|c|c|c|}
\hline TIPO DE APRENDIZAGEM & DEFINIÇÃO & NATUREZA & $\begin{array}{c}\text { AUTORES } \\
\text { REPRESENTATIVOS }\end{array}$ \\
\hline 3M's & $\begin{array}{l}\text { Meaning, Management, and } \\
\text { Measurement. }\end{array}$ & Forma & Garvin (1993) \\
\hline $\begin{array}{l}\text { Simplificação } \\
\text { Especialização }\end{array}$ & $\begin{array}{l}\text { Processos que buscam } \\
\text { simplificar a experiência para } \\
\text { minimizar as interações e } \\
\text { restringir os efeitos da } \\
\text { vizinhança espacial e } \\
\text { temporal das ações. } \\
\text { Processos que tendem a } \\
\text { concentrar atenção e } \\
\text { competência restrita. }\end{array}$ & Processo & $\begin{array}{l}\text { Levinthal; March, } \\
\text { (1993) }\end{array}$ \\
\hline $\begin{array}{l}\text { Deliberada } \\
\text { Emergente }\end{array}$ & $\begin{array}{l}\text { Planejadas e formuladas por } \\
\text { líderes e sustentadas por } \\
\text { mecanismos de controle que } \\
\text { permitam implementação } \\
\text { sem risco. } \\
\text { Impostas pelo ambiente } \\
\text { externo, normalmente de } \\
\text { forma inesperada e em } \\
\text { resposta a situação de } \\
\text { mudança. }\end{array}$ & Estratégia & $\begin{array}{l}\text { Mintzberg; Ahlstrand; } \\
\text { Lampel, (2000) }\end{array}$ \\
\hline Projetos & $\begin{array}{l}\text { Conhecimento com base na } \\
\text { prática; } \\
\text { Projeto de autonomia; } \\
\text { Integração do conhecimento. }\end{array}$ & Forma & $\begin{array}{l}\text { Scarbrough et al. } \\
\text { (2004) }\end{array}$ \\
\hline $\begin{array}{l}\text { STI - Science, Technology, } \\
\text { and Innovation } \\
\text { DUI - Doing, Using, and } \\
\text { Interacting }\end{array}$ & $\begin{array}{l}\text { Baseia-se na produção e } \\
\text { utilização da codificação } \\
\text { científica e conhecimentos } \\
\text { técnicos. } \\
\text { Baseia-se na experiência. }\end{array}$ & Forma & Jensen et al. (2007) \\
\hline Aprendizado colaborativo & $\begin{array}{l}\text { Alianças estratégicas e } \\
\text { eficiência coletiva. }\end{array}$ & Estratégia & Winkelen (2010) \\
\hline
\end{tabular}

Quadro 6 - Processos de aprendizagem

Fonte: Pesquisa bibliográfica. Elaborada pela autora

O próximo tópico será dedicado à explanação das formas de articulação do conhecimento mais comumente utilizadas pelas organizações. 


\subsubsection{Articulação do conhecimento}

Muitos trabalhos sobre 'Aprendizagem Organizacional' não mencionam explicitamente o conhecimento. Este é assumido implicitamente como resultado do processo de aprendizagem (NAKANO; FLEURY, 2005). Os mesmos autores conceituam o conhecimento como sendo "um estado ou propriedade da organização em um dado instante", cabendo à aprendizagem modificar esse estado ou propriedade ao longo do tempo.

Zollo e Winter (2002) acreditam que o conhecimento é capaz de melhorar a competência organizacional, porém, Fleury e Fleury (2000) alertam que o conhecimento por si só não atrai melhorias organizacionais se a empresa não sabe o que fazer com o conhecimento adquirido.

Fleury e Fleury (2000) destacam, então, três processos principais: (1) a aquisição e desenvolvimento do conhecimento, (2) sua disseminação e (3) a construção da memória organizacional.

\subsubsection{Aquisição e desenvolvimento do conhecimento}

A capacidade de absorção do conhecimento está localizada entre os campos da capacitação dinâmica, da aprendizagem organizacional e da gestão do conhecimento (EASTERBY-SMITH et al., 2008) e descreve a capacidade que uma organização tem de compreender o valor do conhecimento e traduzi-lo em uso (Zahra; George, 2002). É vista também como uma das principais contribuições para o desempenho organizacional (COHEN; LEVINTHAL, 1990).

O conhecimento tanto pode ser adquirido do ambiente externo, através de aquisições e outras relações inter-organizacionais, ou interno, através de experiências passadas (EASTERBY-SMITH et al., 2008). 
Nonaka e Takeuchi (1997) veem o conhecimento sob duas dimensões: tácita (conhecimento enraizado nas ações, experiências, emoções, valores e ideias dos indivíduos) e explícita (declarado em livros, manuais, planilhas).

A compreensão da aquisição do conhecimento como processo de transformação do conhecimento tácito em conhecimento explícito tem implicações diretas no modo como a organização projeta e define os papéis e responsabilidades gerenciais. Trata-se da "Gestão do Conhecimento" (NONAKA, 2001).

Nonaka (2001), então, propõem um processo de criação do conhecimento pelo qual as organizações convertem conhecimento tácito em explícito, através de três passos: metáfora, analogia e modelo.

- A metáfora é um método próprio de percepção. É o meio pelo qual indivíduos situados em contextos diferentes e com experiências diversas compreendem algo de maneira intuitiva. Como tal, a metáfora é altamente eficaz em fomentar o comprometimento direto com o processo criativo nos primeiros estágios da criação do conhecimento.

- A analogia é um passo intermediário entre a pura imaginação e o pensamento lógico. Em outros termos, ao esclarecer que, num mesmo contexto, duas ideias podem ser semelhantes e díspares, as contradições expressas pelas metáforas são harmonizadas pela analogia.

- Finalmente, o último passo no processo de criação do conhecimento é o desenvolvimento de um modelo real. Este é concebível com muito mais rapidez do que a metáfora e a analogia. No modelo, resolvem-se as contradições e os conceitos se tornam transferíveis á toda organização por meio de uma lógica consistente e sistemática.

Essa abordagem coloca a criação do conhecimento exatamente em seu lugar: no próprio cerne da estratégia de recursos humanos da empresa. Segundo Nonaka (2001) os novos conhecimentos sempre se originam nas pessoas. 
É tema comum das estratégias mais populares o foco no capital intelectual (WELDY, 2009). Na visão de Quinn, Anderson e Finkelstein (2001) o sucesso das empresas situa-se mais em suas capacidades intelectuais e sistêmicas do que nos ativos físicos, e a capacidade de gerenciar esse intelecto humano - e de convertê-lo em produtos e serviços úteis - é a habilidade executiva mais crítica deste século.

Kleiner e Roth (2001) compartilham da mesma ideia, mas ressaltam que as pessoas na organização agem de maneira coletiva, dificultando a gestão do intelecto, o que é visto como fonte de frustração do aprendizado organizacional.

Para minimizar esta frustração, Nonaka et al. (1994) defendem a ideia de que, independente das dimensões e/ou perspectivas, as formas de conhecimento devem se complementar para aumentar o conhecimento coletivo, beneficiando a gestão do conhecimento nas organizações e gerando maior competitividade no mercado através da sua disseminação.

\subsubsection{Disseminação do conhecimento}

A transferência do conhecimento nas organizações é o processo através do qual uma unidade (individual, grupo, departamento, divisão) é afetada pela experiência de outra (ARGOTE et al., 2000).

Zollo e Winter (2002) retomam atenção ao desenvolvimento da competência coletiva, através do qual o conhecimento implícito é articulado por meio de discussões coletivas, sessões de esclarecimentos e processos de avaliação de desempenho. Segundo os autores, ao partilhar suas experiências individuais e comparar suas opiniões com as de seus colegas, os membros da organização podem atingir um melhor nível de compreensão dos mecanismos de aprendizagem, entre as ações necessárias para executar uma determinada tarefa e os resultados de desempenho produzidos. 
Sob a ótica de Carlsson, Fernebro e Khakhar (1991), a perspectiva do conhecimento é vista como um estado da mente e se concentra em capacitar as pessoas a expandir seus conhecimentos pessoais e aplicá-los na organização. Contudo, Kleiner e Roth (2001) acreditam que muitas vezes os gerentes dispõem de poucas ferramentas para captar a experiência institucional e disseminar seu conhecimento, o que torna o processo de gestão mais complexo.

Sob o ponto de vista de Quinn, Anderson e Finkelstein (2001), superar a relutância dos profissionais em compartilhar as informações é tarefa crítica para os gestores, pois, ao contrário dos ativos físicos, os ativos intelectuais aumentam o valor com o uso (QUINN; ANDERSON; FINKELSTEIN, 2001).

Ainda segundo Quinn, Anderson e Finkelstein (2001), a competição entre os profissionais frequentemente inibe o compartilhamento do conhecimento, porém, sob estímulos adequados, o conhecimento e o intelecto crescem exponencialmente quando compartilhados. Se duas pessoas trocam conhecimentos entre si, ambas ganham informação e crescem de maneira linear. Mas se ambas compartilham seus novos conhecimentos com outros, os benefícios vão se tornando exponenciais.

Este julgamento também vale para as empresas que aprendem com o público externo - especialmente com clientes, fornecedores e especialistas, como empresas de projetos ou softwares avançados - e assim, tornam-se capazes de auferir benefícios ainda maiores. As consequências estratégicas da exploração desse crescimento exponencial são profundas. Quando a empresa desenvolve vantagem competitiva baseada em conhecimento, torna-se ainda mais fácil para ela manter a liderança e mais difícil para os concorrentes superar a diferença (QUINN; ANDERSON; FINKELSTEIN, 2001).

As diferentes perspectivas do conhecimento levam as empresas a desenvolverem diferentes estratégias para sua gestão (McQUEEN, 1998). A Gestão do Conhecimento surge como abordagem integrada sobre a necessidade tanto de compreender quanto de gerir os fluxos reais e potenciais da criação, transferência e retenção do conhecimento (PRIETO; EASTERBY-SMITH, 2006). Trata-se de uma 
corrente de pesquisa que compartilha conceitos e apresenta convergência com a aprendizagem organizacional (EASTERBY-SMITH et al., 2000).

Um dos principais focos da gestão do conhecimento é a prestação de soluções tecnológicas, tais como a introdução de intranets, a criação de banco de dados, os repositórios de conhecimento ou a criação de diretórios de especialização.

O conhecimento pode ser visto, portanto, como um objeto, algo que pode ser armazenado e manipulado; como um processo de conhecer e agir simultaneamente; ou ainda, como uma condição de acesso à informação (McQUEEN, 1998).

É na perspectiva da 'informação' que Alavi e Leidner (2001) descrevem os sistemas de gestão do conhecimento. Para os autores, os sistemas de gestão do conhecimento "referem-se a uma classe de sistemas de informação aplicadas à gestão do conhecimento organizacional", visão também compartilhada por Prieto e Esaterby-Smith (2006). Trata-se de sistemas baseados em tecnologia da informação (TI), desenvolvidos para apoiar e otimizar processos de criação, armazenamento, recuperação e transferência de conhecimentos.

Os exemplos incluem uma fonte de conhecimento registrado usando diretórios online e busca em bases de dados, planilha de conhecimentos e de trabalhos junto às equipes virtuais, o acesso à informação sobre projetos anteriores, análises de dados e transações visando compreender o comportamento e as necessidades de cliente, entre outros (ALAVI; LEIDNER, 2001).

Alavi e Leidner (2001), revendo a literatura que discute aplicações de TI para a gestão do conhecimento, identificaram três aplicações comumente encontradas nas organizações:

1) A codificação e a partilha das melhores práticas - uma das aplicações mais comuns é o benchmarking interno com objetivo de transferir as melhores práticas internas a diferentes departamentos, possibilitando soluções melhores. 
2) A criação de diretórios do conhecimento corporativo - trata-se do mapeamento das competências e/ou especializações internas da organização. Este mapeamento é uma aplicação potencialmente útil na gestão do conhecimento e incentiva a aplicação do conhecimento existente.

3) A criação de redes de conhecimento - trata-se da criação de plataformas de conhecimento que reúnem especialistas de diferentes áreas, cujo objetivo é promover a troca de conhecimento entre os membros. Neste caso, o esforço da gestão está em propor discussões que possam promover novos conhecimentos na rede.

Os sistemas de gestão do conhecimento, por serem flexíveis à medida da necessidade de cada organização, inspiram os gestores a utilizar as ferramentas de TI para promover o apoio aos processos de gestão do conhecimento. Desta forma, caberá a cada empresa identificar e adequar o sistema de gestão do conhecimento que melhor se adeque aos seus objetivos e necessidades.

Argote et al. (2000) defende a ideia de que uma gestão eficaz exige que o conhecimento seja transferido entre funcionários, equipes, departamentos e divisões geográficas. Outra tendência de negócio aponta para a necessidade de alianças estratégicas entre empresas, fusões e aquisições. Desta forma, as organizações podem aprender não só através da sua própria experiência, mas também da experiência de outras organizações.

Outra forma de transferência do conhecimento, muito comumente utilizada nas empresas, é o programa de treinamento. A ênfase nos programas de treinamento deve garantir a aprendizagem e a transferência de informações como um meio de aumentar a base de conhecimento dos trabalhadores. Trata-se de uma estratégia importante a ser seguida pelas empresas, além de ser uma ferramenta valiosa para melhorar o desempenho da organização (WELDY; 2009, BATES; 2001; GEPHART et al., 1996). 


\subsubsection{Construção da memória organizacional}

Para Fleury e Fleury (2006), existem diferentes estratégias na construção da memória organizacional (banco de dados, comunidades práticas ${ }^{2}$, etc.) e cabe à empresa definir qual delas melhor de adequa aos seus objetivos.

A construção da memória organizacional refere-se ao processo de armazenagem das experiências da empresa (FLEURY; FLEURY, 2006) através da conversão do conhecimento individual em recurso disponível para outras pessoas (NONAKA, 2001).

Winter (2003) acredita que esta conversão do conhecimento em recurso disponível é alcançada através da rotina, que ele define como sendo um comportamento altamente padronizado que é aprendido, repetitivo (ou quase repetitivo), fundado parte por conhecimento tácito e parte pela especificidade de objetivos. São padrões estáveis de comportamento que caracterizam as reações organizacionais com base em estímulos internos ou externos (ZOLLO; WINTER, 2002) e servem para entender como os recursos organizacionais são acumulados, transferidos e aplicados (COHEN et al., 1996). Uma proposição central da teoria das rotinas é que as organizações mudam o que estão fazendo e como estão fazendo alterando suas rotinas (BECKER, et al., 2005).

É no conceito das "rotinas" que este estudo fará maior aprofundamento, tendo como objetivo elucidar o terceiro mecanismo de aprendizagem de Zollo e Winter (2002), intitulado "codificação do conhecimento".

\footnotetext{
${ }^{2}$ Comunidades práticas são grupos formados em torno da prática de sua profissão, ligados pela necessidade de partilharem experiências e desenvolverem conhecimento coletivo (FLEURY; FLEURY, 2006).
} 


\subsubsection{Codificação do conhecimento: rotinas}

A atividade de rotina de uma organização constitui a sua forma mais importante de estocagem do conhecimento específico. Há também a questão de saber quais e quando as rotinas devem ser seguidas. Para o membro individual, isso implica a habilidade de receber e interpretar um fluxo de mensagens enviadas por outros membros e pelo ambiente. Mesmo as diretrizes que parecem estar claras, frequentemente requerem interpretação de um modo que é bastante específico ao contexto da organização (NELSON; WINTER, 2005).

As rotinas também são vistas como processos gerenciais (TIDD; BESSANT; PAVITT, 2008) ou sistemas de gestão (TAKAHASHI; TAKAHASHI, 2007) que orientam a acumulação e o uso estratégico dos recursos da empresa. É certo que as rotinas organizacionais são maleáveis por influência gerencial deliberada, mas também se alteram endogenamente porque os atores humanos estão envolvidos na realização das rotinas e, quase sempre, tem a possibilidade de alterá-las (FELDMAN, 2000). Nesse sentido, da mesma forma que as rotinas preservam o conhecimento (memória organizacional), elas também representam uma fonte de mudança da organização (BECKER; LAZARIC, 2003).

A interdependência entre os participantes em uma rotina, e entre várias rotinas, representa mais de uma fonte de mudança endógena que está ligada as rotinas organizacionais. Devido a essa interdependência, o desejo de um participante em uma rotina para substituir, por exemplo, uma ferramenta utilizada na realização da rotina por outra, pode desencadear efeitos que resultam em pressão e à substituição da velha rotina por uma nova (BECKER et al., 2005).

Seja como consequência incidental de atitudes, seja como atos deliberados de comunicação, a execução de rotinas individualmente pelos membros da organização, gera um fluxo de mensagens para outros. Essas mensagens, por sua vez, são interpretadas como solicitação de desempenhos específicos de seus receptores, que geram outros desempenhos, mensagens, interpretações, e assim por diante. Há, na verdade, um fluxo circular internamente equilibrado de 
informações nas organizações em operação rotineira, mas trata-se de um fluxo que é continuamente oprimido por fontes externas de mensagens e por equipamentos de controle de tempo (NELSON; WINTER, 2005).

As rotinas organizacionais têm tanto aspectos tecnológicos quanto aspectos sociais e, muitas vezes, esses estão interligados. Os aspectos tecnológicos estão ligados às práticas como, por exemplo, o just-in-time, os cartões kanban, etc. Já os aspectos sociais referem-se às atitudes e práticas pessoais (no sentido da qualidade, por exemplo) e práticas sociais, como é o caso dos funcionários fornecendo sugestões à empresa (BECKER et al., 2005).

O elemento central do desempenho produtivo de uma organização é a coordenação; por sua vez, o elemento central da coordenação está no fato de os membros individuais, sabendo seus ofícios, interpretarem e responderem corretamente às mensagens que recebem. Se a descrição apresentada for clara, as habilidades, a organização e a tecnologia estão interligadas numa rotina funcional e torna-se difícil dizer com exatidão onde termina um aspecto e onde começa o outro (NELSON; WINTER, 2005).

Para Nelson e Winter (2005) as memórias dos membros guardam de fato a informação requerida para a execução das rotinas da organização, há uma verdade substancial na proposição de que o conhecimento possuído por uma organização é redutível ao conhecimento de seus membros individuais.

Porém, o conhecimento guardado na memória humana só tem significado e eficácia em algum contexto, e, para o conhecimento exercitado em uma função organizacional, esse contexto é o da organização. Isso inclui uma variedade de formas, como a memória externa, que complementa e apoiam as memórias individuais - arquivos, quadros de avisos, manuais, memórias de computadores, fitas magnéticas - e o estado físico dos equipamentos e do ambiente de trabalho de um modo geral - equipamentos e estruturas são relativamente duráveis e o estado geral do ambiente de trabalho não passa por mudanças radicais e descontínuas (NELSON; WINTER, 2005). 
Uma organização constitui um sistema aberto que sobrevive por intermédio de alguma forma de intercâmbio com o seu meio ambiente. A rotina da organização, considerada abstratamente como "modo de fazer as coisas", é uma ordem que só pode persistir se for imposta a um conjunto específico de recursos em contínua mutação (NELSON; WINTER, 2005). A mudança da rotina pode vir por iniciativa da administração ou por forças e ações dos agentes internos à rotina (BECKER et al., 2005).

O problema que se coloca para a firma é de como adquirir insumos com as características particulares requeridas para o funcionamento regular de suas rotinas, diante do fato de que tais insumos podem não estar disponíveis no mercado ou, se estiverem, podem não ser imediatamente distinguíveis de outros insumos menos eficientes. Uma tática é selecionar as alternativas disponíveis no mercado que são compatíveis com a rotina. A perda de um funcionário com importantes conhecimentos idiossincráticos, por exemplo, representa uma ameaça fundamental à continuidade da rotina - de fato, se sua saída for imprevista, a continuidade será necessariamente rompida e haverá uma mudança na rotina da organização. (NELSON; WINTER, 2005).

De um modo geral, a rotina existente serve como modelo para a nova. O uso de modelos torna possível a reprodução relativamente precisa de um sistema em funcionamento que é amplo e complexo para ser aprendido por uma única pessoa. Sendo assim, torna-se explícita a necessidade de que os membros possuam habilidades para desempenhar suas funções (NELSON; WINTER, 2005).

O projeto de promover a compreensão da mudança da organização através da análise das rotinas organizacionais tem sido enfraquecido um pouco por problemas na aplicação da noção de rotinas organizacionais na pesquisa empírica (BECKER et al., 2005). Williamson (1999), também lançou sua crítica às rotinas como forma de capacitação dinâmica devido à falta de fundamentação empírica. De fato, uma das características mais insatisfatórias de mais de duas décadas de pesquisa em rotinas organizacionais é o lento progresso na compreensão de como as rotinas organizacionais emergem, como elas mudam, e que impacto tem nas organizações (BECKER et al., 2005). 
Felin e Foss (2011), com base na literatura, resumem as operações de rotina como sendo uma relação determinista entre várias entradas e saídas associadas, em que fatores externos (experiência, estímulo, ambiente, etc.) determinam os resultados.

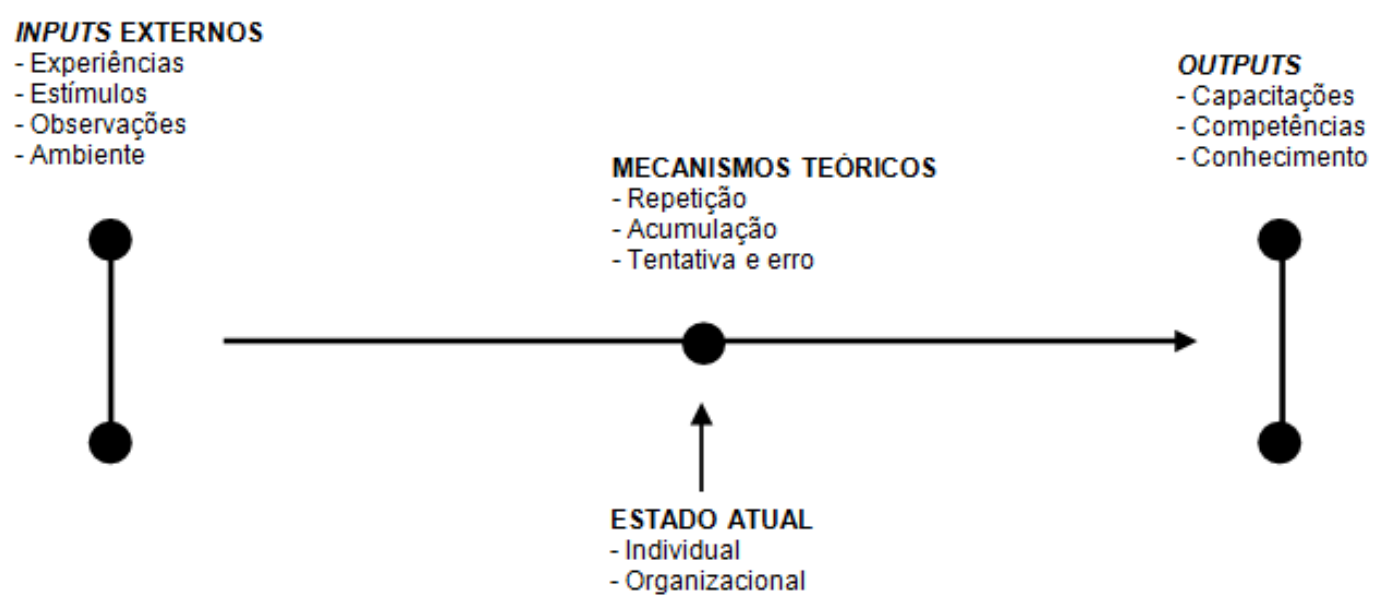

Ilustração 1 - Modelo simplificado de entradas/saídas de rotinas organizacionais e capacitações. Fonte: Adaptado de Felin e Foss (2011).

Contudo, Felin e Foss (2011) lançam a seguinte questão: Quais seriam as origens da experiência ou da repetição de uma atividade? Na opinião dos autores, esta questão não pode ser adequadamente respondida com fundamentos empiristas, argumentando que a experiência, assim como as rotinas e as capacitações organizacionais, tem origem endógena; tal afirmação sugere que as condições iniciais da experiência é que sejam estudadas (as escolhas, a natureza e as habilidades do indivíduo e da organização).

Em resposta às provocações de Felin e Foss (2011), Winter (2011) dedica-se a explicar que pode ter havido um mal entendido, por parte dos autores, quanto aos fins pelos quais as rotinas organizacionais foram estudadas. Pelo menos na economia evolucionária, os conceitos de rotinas e capacitações foram apresentados como componentes de uma teoria do comportamento organizacional, sendo esta teoria descritiva, ou seja, uma teoria preditiva / explicativa e não normativa / prescritiva. 
Certamente, as teorias de Winter em parceria com Nelson (2005) ou Zollo (2002), não afirmam que as organizações devem evitar à criatividade ou o exercício do livre arbítrio, ao contrário, a teoria das rotinas vem propor a implantação de uma ou várias atividades, em sequência lógica, com base em observações empíricas repetitivas (WINTER, 2011).

Aos olhos de Winter (2011), fornecer uma descrição teórica totalmente convincente da origem das rotinas e das capacitações é, de fato, uma meta desafiadora e pouco possível no presente.

A opinião de Pentland (2011) quanto às provocações de Felin e Foss (2011), sugere que os autores caíram numa armadilha ao falar das rotinas de Winter fora do contexto em que são trabalhadas. Os autores criaram problemas filosóficos sobre a rotina organizacional, utilizando conceitos fora do seu significado na prática, ou seja, eles escrevem sobre "experiências" e "rotinas" em geral, ao invés de escrever sobre qualquer experiência específica ou de rotina.

Sem dúvida, o termo "rotina organizacional" refere-se a um complicado fenômeno, muitas vezes mal compreendido. Para evitar confusões, é útil considerar como exemplo concreto uma atividade que satisfaça a definição de uma rotina organizacional, ou seja, a atividade é repetitiva, produz um padrão reconhecível de ações onde as ações são interdependentes e há múltiplos atores envolvidos. Se qualquer peça da definição está ausente, o fenômeno não é uma rotina organizacional (PENTLAND, 2011).

Em suma, Felin e Foss (2011) defendem a necessidade de avançar na análise causal do por que as rotinas se formam, por que mudam, e assim por diante. As questões seriam razoáveis, não fosse o erro dos autores em invocar a teoria inadequada para respondê-las (PENTLAND, 2011), e de serem pouco claros no uso da terminologia adotada e confusos em suas reivindicações (HODGSON; KNUDSEN, 2011).

O conceito de rotinas continua sendo explorado por diversos autores na tentativa de compreender a verdadeira natureza das capacidades dinâmicas da empresa 
(CEPEDA; VERA, 2007). Collis (1994) aponta duas categorias de capacidades: a primeira reflete a capacidade de executar as atividades funcionais básicas da empresa como, por exemplo, a logística de distribuição, o layout da fábrica, etc.; a segunda trata do dinamismo em si, no que tange a melhoria das atividades.

A capacidade dinâmica é exemplificada, segundo Zollo e Winter (2002), por um padrão de atividade coletiva através da qual a organização gera e modifica suas rotinas operacionais em busca de maior eficácia. É neste conceito que o presente texto visa construir seu conceito para as capacitações dinâmicas.

O próximo tópico trará alguns conceitos das capacitações dinâmicas, vista sob a forma de rotinas, e apontará onde estes conceitos se complementam.

\subsection{CAPACITAÇÕES DINÂMICAS}

Optou-se por iniciar a abordagem deste tópico descrevendo o que são as capacitações básicas de uma empresa.

Teece, Pisano e Shuen (1997) definem as capacitações básicas de uma empresa como processos tecnológicos, organizacionais e gerenciais internos. Na visão de Winter (2003), as capacitações básicas são exercidas quando uma empresa opera em perfeito equilíbrio, produzindo o mesmo produto, na mesma escala, para o mesmo consumidor o tempo todo.

Porém, este equilíbrio está cada vez mais distante da realidade do mundo atual, onde empresas operam com vários produtos, com demandas e mercados diferenciados e atendendo a consumidores distintos. A literatura das capacidades dinâmicas procura, portanto, estudar o potencial das empresas em se adaptar aos ambientes turbulentos, que exigem rápidas mudanças e reconfigurações.

As empresas que operam em ambientes com mudanças constantes são impulsionadas a buscar maior vantagem competitiva através do aprimoramento dos 
seus processos internos. Trata-se de uma forma eficaz de identificar novas oportunidades e se reorganizar para gerar novas riquezas. Essa habilidade de reconhecer novas oportunidades depende, em parte, da capacidade do indivíduo e do seu conhecimento (TEECE, 2007). Neste contexto, há que se considerar a imprecisão conceitual das capacitações dinâmicas e a pouca operacionalização na sua medição (Winter, 2003), o que Pavlou e Sawy (2005) chamam de "caixa preta das capacitações dinâmicas".

Vista como fonte de vantagem competitiva, a capacitação dinâmica enfatiza o papel fundamental da gestão estratégica em adaptar, integrar e reconfigurar as habilidades, os recursos e as competências funcionais da organização, em relação a um cenário de mudança (TEECE; PISANO; 1994). Porém, uma capacitação dinâmica não implica necessariamente em constante mudança, mas em potencial para estender, alterar ou criar esses recursos e rotinas internas conforme apropriado (PRIETO; EASTERBY-SMITH, 2006).

Autores como Teece; Pisano; Shuen, (1997), Eisenhardt; Martin, (2000), Winter (2000), Zollo; Winter, (2002), Teece et al. (1997), vinculam o conceito de 'capacitações dinâmicas' ao arcabouço das estratégias empresariais como forma de vantagem competitiva da empresa, o que Takahashi e Takahashi (2007) complementam, incluindo a este conceito "o desenvolvimento das capacidades gerenciais e as combinações de habilidades tecnológicas, funcionais e organizacionais".

Capacitações dinâmicas são definidas, portanto, como sendo um conjunto de processos específicos e identificáveis, tais como desenvolvimento de produtos, decisões estratégicas e alianças (EISENHARDT; MARTIN, 2000) que operam para integrar, estender ou modificar recursos (WINTER, 2003) e são capazes de responder a modificações de forma rápida (TEECE; PISANO; SHUEN, 1997), através da geração e modificação de suas rotinas operacionais (ZOLLO; WINTER, 2002), o que se reverte em novas estratégias de agregação de valor para a empresa (SANTOS; EISENHARDT, 2005). 
Várias definições de capacitações dinâmicas estão disponíveis na literatura. O conceito tem sido difundido por vários autores, o que proporciona ao leitor um vasto arcabouço literário para pesquisa. Porém, há pouco consenso sobre sua definição.

Apesar da falta de acordo quanto à natureza das capacitações dinâmicas, segundo Cepeda e Vera (2007), há um consenso quanto à necessidade de uma hierarquia das capacitações, levando em conta quatro aspectos críticos:

1) Capacidades são processos organizacionais e rotinas enraizadas no conhecimento;

2) A entrada da capacidade dinâmica é uma configuração inicial de recursos e rotinas operacionais;

3) Capacidades dinâmicas envolvem um processo de transformação de recursos e do conhecimento da empresa em rotinas;

4) A saída das capacidades dinâmicas é uma nova configuração de recursos e rotinas operacionais.

Em um esforço mais abrangente de articular o conhecimento e as capacidades dinâmicas explicitamente, Zollo e Winter (2002) propõem o que chamam "ciclo de evolução do conhecimento". Este ciclo permite que as empresas mudem a maneira de fazer as coisas, na busca de vantagens. O ciclo é formado por quatro fases: variação generativa, seleção interna, replicação e retenção. 


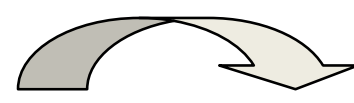

VARIACÃO GENERATIVA

Indivíduos e grupos geram ideias sobre como abordar velhos problemas e novas formas de enfrentar desafios.

\begin{tabular}{|l|}
\hline SELEÇÃO INTERNA \\
Implica a avaliação de \\
ideias para melhorar o \\
potencial e a eficácia \\
da empresa. \\
\end{tabular}

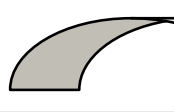

Envolve a codificação da opção selecionada, além da sua difusão para as partes interessadas na empresa.

Ilustração 2 - Ciclo de evolução do conhecimento

Fonte: Adaptado de Zollo e Winter (2002).

Segundo Pavlou e Sawy (2005), as capacidades dinâmicas têm sido estudadas em nível conceitual, através de estudos de caso qualitativos, enquanto sua natureza exata ainda não é bem compreendida (PRIETO; EASTERBY-SMITH, 2006). Reconfigurar os recursos da empresa (instalações, produção, capital financeiro) é relativamente fácil, porém, há que se considerar a importância do conhecimento como recurso intangível. Por isso a necessidade de codifica-lo (Winter, 2003).

As melhores práticas para compor as capacitações dinâmicas são definidas internamente na empresa, observando-se o que funcionou bem e o que tem maior probabilidade de funcionar bem no futuro se for repetido (KERZNER, 2004).

A abordagem das capacitações dinâmicas que será adotada para o desenvolvimento desta pesquisa, especialmente com relação aos recursos baseados no conhecimento da empresa, será feita com base nas rotinas.

Tais capacitações incluem alianças e aquisições de empresas, que trazem novos recursos a partir de fontes externas (CAPRON; MITCHEL, 2009).

O próximo tópico trará os indicadores escolhidos para que seja possível, quantitativamente, medir a evolução das capacitações da empresa. 


\subsection{INDICADORES DE EVOLUÇÃO DA EMPRESA}

Tomando-se por base o foco desta pesquisa, que visa analisar a criação de capacitações 'dinâmicas' na empresa, torna-se pré-requisito a utilização de uma ferramenta que permita medir o dinamismo das capacitações, que se configuram no tempo e no contexto do estudo sendo, neste caso, retrospectivo (pesquisa do passado) e longitudinal (pesquisa do presente).

Para tanto, serão destacados 4 indicadores, cuja função básica será aferir a evolução das capacitações no período analisado:

1) Número de softwares desenvolvidos e/ou utilizados nos projetos analisados;

2) Número de engenheiros contratados pela empresa de serviços de engenharia;

3) Número de rotinas criadas pela empresa de serviços de engenharia;

4) Número de alianças/parcerias com outras empresas.

Esta análise será apresentada no capítulo 6 - pesquisa de campo fase 2 - que buscou identificar nas empresas pesquisadas a evolução das capacitações através da análise de três projetos distintos, obedecendo a uma ordem cronológica que possibilitou tal verificação.

\subsection{SÍNTESE}

O referencial teórico desta pesquisa trouxe a proposta de Zollo e Winter (2002) que, através dos mecanismos de aprendizagem, procuram fornecer uma base clara para a análise dos processos de aprendizagem que formam as rotinas e as capacitações dinâmicas na empresa. 
Conforme mostra o quadro, os principais conceitos que se pretende empregar nesta pesquisa correspondem à capacidade de aprendizagem da empresa, a absorção, o desenvolvimento e a construção da memória organizacional através da gestão do conhecimento e, finalmente, a codificação do conhecimento por meio das rotinas.

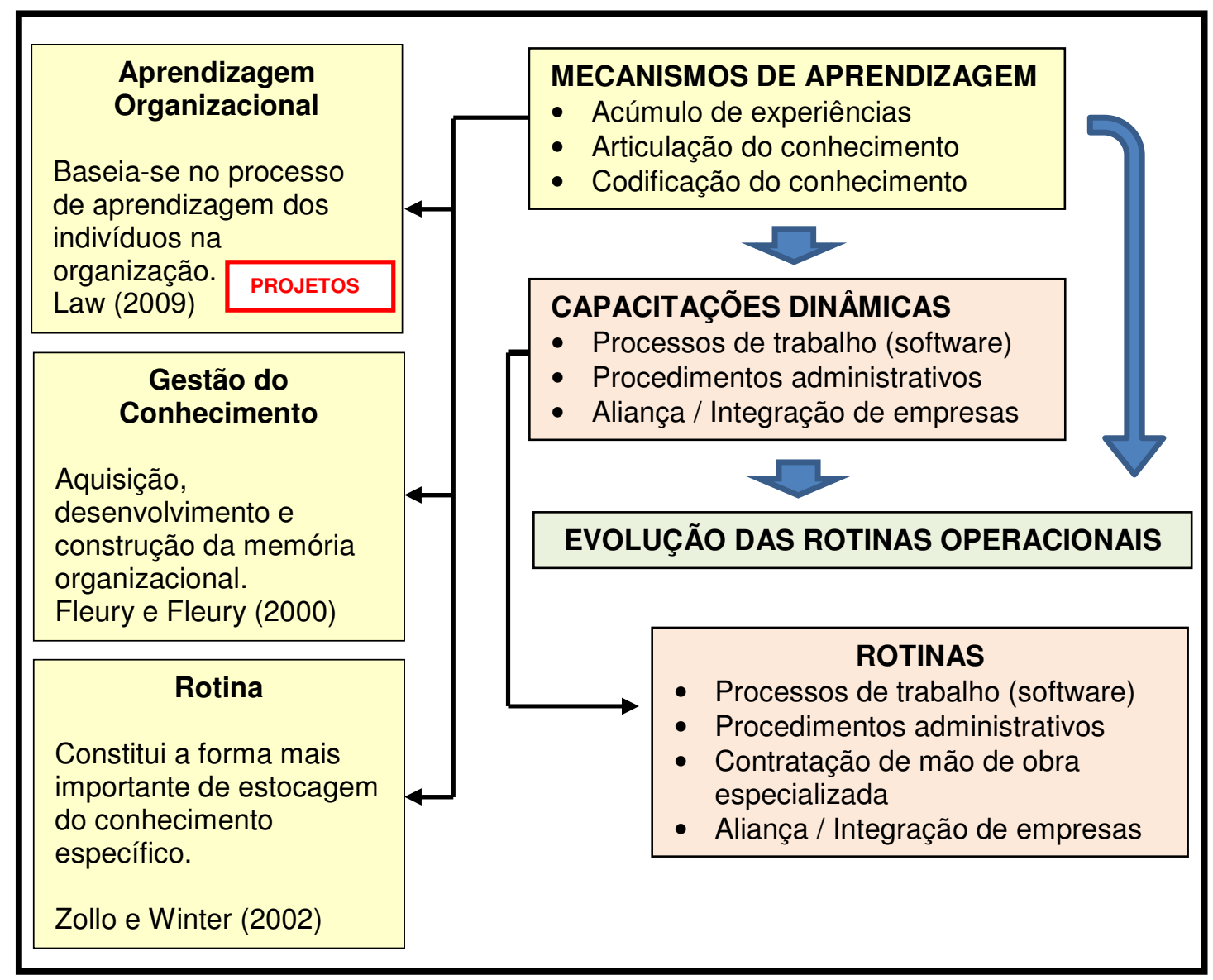

Quadro 7 - Síntese do referencial teórico

Fonte: Revisão teórica. Elaborado pela autora.

A evolução das capacitações da empresa será analisada com base em quatro indicadores: processos de trabalho, procedimentos administrativos, contratação de mão-de-obra especializada e alianças e/ou integração de empresas.

Espera-se encontrar evidências dos conceitos apresentados nesse referencial teórico quando aplicados aos estudos de caso a que se propôs a presente pesquisa. 


\section{METODOLOGIA E PROCEDIMENTOS}

O presente capítulo trará informações acerca do processo metodológico a ser utilizado na condução da pesquisa. Inicia-se o capítulo pela apresentação das questões e hipóteses que guiarão o texto e, na sequência, serão descritas as características que nortearão o projeto da pesquisa, destacando o universo, a amostra e as fases de sua concepção.

\subsection{QUESTÕES E HIPÓTESES}

A definição da questão e das hipóteses no início da pesquisa, ainda que em termos amplos, é importante para focalizar os esforços e não se deixar perder no grande volume de dados investigados (EISENHARDT, 1989).

Para Marconi e Lakatos (2006), a questão de pesquisa (ou problema de pesquisa) é uma dificuldade teórica ou prática no conhecimento de algo importante, para o qual se deve encontrar uma solução. Para tanto, originou-se a seguinte questão:

Como se dá a construção das capacitações dinâmicas nas empresas de serviços de engenharia, a partir das exigências cadastrais e contratuais do seu principal cliente: a Petrobras?

A questão de pesquisa deve ser especificada com clareza, concisão e objetividade para facilitar a construção das hipóteses ou proposições centrais. A hipótese, neste caso, é uma proposição que se faz na tentativa de verificar a validade da resposta dada à questão da pesquisa. Trata-se de uma suposição que antecede a constatação dos fatos, tendo como característica uma formulação provisória que deve ser testada para a verificação da sua validade. Os mesmos autores defendem a ideia de que não há regras para a formulação de hipóteses em trabalhos de pesquisa científica, porém é necessário que haja embasamento teórico e que as 
hipóteses sejam formuladas de maneira a servir como um guia na atividade investigativa (MARCONI E LAKATOS, 2006).

Para responder a questão da pesquisa, com base nos principais conceitos que a norteiam, foram identificadas duas proposições, apresentadas a seguir:

Proposição 1 - Dada as exigências cadastrais e contratuais da Petrobras, as empresas de serviços de engenharia são obrigadas a proceder com mudanças técnicas, organizacionais e estruturais para se adequarem ao perfil dos fornecedores da contratante.

Proposição 2 - As experiências obtidas através dos projetos executados para a Petrobras são as principais fontes para a criação das capacitações dinâmicas pelas empresas de serviços de engenharia, considerando a aprendizagem e a absorção do conhecimento obtido.

Outras questões que se pretende responder:

- Quais as principais características que norteiam a relação das empresas de serviços de engenharia com a Petrobras?

- Como as empresas de serviços de engenharia aproveitam o conhecimento obtido em projetos da Petrobras para desenvolver suas capacitações dinâmicas?

Segue-se então a construção metodológica que guiará o estudo.

\subsection{PROJETO DA PESQUISA}

Existem várias formas para se construir um projeto de pesquisa e cada uma descreve quais etapas devem ser seguidas. Segundo Ghauri, Gronhaug e Kristianlund (1995), o processo de pesquisa científica inicia-se com a definição do 
problema que será estudado, tendo o pesquisador o dever de responder a duas questões: qual é o problema? E como será resolvido?

Nakano e Fleury (2005), enfatizando a pesquisa em engenharia de produção, sugerem dois métodos de análise: método qualitativo e método quantitativo. No grupo dos métodos denominados qualitativos, que se caracterizam por um maior foco na compreensão dos fatos do que propriamente na sua mensuração, Lazzarini (1995) enquadra a pesquisa através de estudos de caso como uma das mais utilizadas.

O estudo de caso tem caráter de profundidade e detalhamento, sendo o método mais indicado para situações onde o problema de pesquisa é abrangente (VERGARA, 2009). Torna-se mais eficaz quando o objetivo é construir teorias e/ou evidências de cunho qualitativo, pois permite compreender mais profundamente 0 fenômeno dentro do seu próprio contexto (LAZZARINI, 1995).

Além disso, a realização de estudos de caso proporciona enriquecimento de conhecimento para o pesquisador e aumenta os entendimentos sobre eventos reais e contemporâneos (CAUCHICK, 2007).

Ao optar pelo método do estudo de caso, torna-se possível o emprego de múltiplas fontes de evidência, como: entrevistas (estruturadas, semi-estruturadas ou não estruturadas), análise documental, observações e, em alguns casos, o levantamento do tipo survey. (MIGUEL, 2010).

Este método centra-se fundamentalmente nas questões "como" e "por que" (LAZZARINI, 1995), além de "o quê" (CAUCHICK, 2007), que apresentam natureza mais explanatória, lidando com relações que se configuram no tempo e no contexto do estudo que, no caso da presente pesquisa, será retrospectivo (pesquisa do passado) e longitudinal (pesquisa do presente).

Esta escolha visa estabelecer uma comparação entre as capacitações das empresas de serviços de engenharia antes dos contratos com a Petrobras e as capacitações 
que foram obtidas a partir desses contratos, até junho de 2011, época em que foram finalizadas as pesquisas de campo.

Portanto, a pesquisa realizada neste trabalho, tendo em vista o seu objetivo, será de natureza qualitativa e será conduzida pelo método de estudo de múltiplos casos, com a finalidade de proporcionar o aumento da validade externa.

Voss, Tsikriktsis e Frohlich (2002) ressaltam que a validade dos resultados obtidos em um estudo de caso depende do rigor na concepção dos protocolos e dos instrumentos de pesquisas utilizados.

Foi com intuito de evitar a ocorrência das limitações citadas que se adotou a opção de realizar estudos de múltiplos casos, de forma a obter maior amostragem para análise dos dados colhidos e, portanto, melhor equacionamento dos resultados.

Segundo Yin (1994), a decisão sobre o número de casos a serem estudados dependem do grau de certeza que se quer obter dos resultados da pesquisa. A vantagem em utilizar múltiplos casos está no fato de reforçar as evidências encontradas e aumentar o grau de generalização dos resultados.

Seguindo a orientação de Eisenhardt (1989), estruturaram-se os estudos de caso seguindo as etapas:

\subsubsection{Definição da estratégia de pesquisa}

Segundo Eisenhardt (1989), definir a estratégia de pesquisa é tratar da seleção dos casos a serem estudados, dos métodos de apropriação dos dados, da preparação de questionários e dos protocolos de pesquisa. Adiciona-se a esta estratégia a importância dada por Vergara (2009) em apresentar ao leitor o universo e a amostra da pesquisa, onde universo é o conjunto de empresas que possuem as características que serão objeto de estudo e a amostra é uma parte deste universo, escolhida segundo algum critério de representatividade. 


\subsubsection{Seleção dos casos}

O universo que compõe o objeto de análise são as empresas fornecedoras de serviços de engenharia cadastradas no banco de dados da Petrobras. Com base neste universo, foram selecionadas as 15 empresas que obtiveram maior receita através de contratos com a Petrobras entre os anos de 1998 a $2007^{3}$, sendo que 14 aceitaram participar da pesquisa.

\subsubsection{Apropriação dos dados}

Quanto à apropriação dos dados, o método utilizado combinou diversas fontes, como: entrevistas estruturadas (com pessoal de nível estratégico e operacional), observações in loco e análise documental.

Vale ressaltar que a apropriação dos dados deu-se em duas fases:

$\mathrm{Na}$ fase 1 , do total da amostra de 14 empresas, e considerando fatores como disponibilidade e localização, foi possível realizar entrevistas presenciais em 7 empresas. Dada à convergência observada nas empresas optou-se, conforme preceito de Eisenhardt (1989), por ampliar a abrangência do levantamento nas demais empresas através de contatos telefônicos, teleconferências e e-mail, das quais 7 empresas participaram.

O roteiro preparado para a fase 1 visou a coleta de dados gerais sobre o impacto dos contratos da Petrobras nas empresas de serviços de engenharia. Foram questionadas características da evolução das empresas em decorrência da interação com a Petrobras, onde se buscou verificar informações como: tempo da relação, exigências da Petrobras para inserção da empresa em seu cadastro de fornecedores, detalhes sobre o ganho de contratos, mudança estrutural em

\footnotetext{
${ }^{3}$ Dados fornecidos pela Petrobras ao Ipea na ocasião da contratação do projeto intitulado "Poder de Compra da Petrobras: Impactos econômicos nos seus fornecedores".
} 
decorrência dos contratos (ou do cadastro), a aprendizagem decorrida das interações, e outras informações acerca das relações contratuais. O roteiro, na íntegra, poderá ser verificado no apêndice 1.

$\mathrm{Na}$ fase 2, todas as empresas participantes da primeira fase foram contatadas, sendo que 3 mostraram-se dispostas a continuar contribuindo com a pesquisa. $O$ roteiro buscou coletar dados de 3 projetos distintos em cada empresa onde, para cada projeto, foram analisados, além de detalhes gerais, quatro variáveis: aumento no número de pessoal especializado contratado (engenheiros), número de softwares utilizados / desenvolvidos, número de rotinas acumuladas, número de alianças/parcerias entre empresas.

O roteiro preparado para a fase 2 da pesquisa teve como objetivo principal coletar informações específicas para responder a questão de pesquisa desta dissertação. Foram, então, coletadas informações que visavam analisar como são criadas as capacitações dinâmicas através das relações contratuais entre as empresas de serviços de engenharia e a Petrobras. Neste caso, o roteiro buscou informações gerais sobre como a empresa de engenharia se articula para criar suas capacitações e atender aos projetos da Petrobras, ou seja, como ocorre a absorção do conhecimento obtido através de cada projeto realizado e, ainda, como este conhecimento é codificado na empresa. Este roteiro poderá ser verificado na íntegra no apêndice 2 .

\subsubsection{Protocolos da Pesquisa}

Os protocolos da pesquisa visam estabelecer equidade dos métodos de coleta de dados em todas as empresas participantes, de forma que haja maior convergência dos resultados da análise (VERGARA, 2009).

Este protocolo descreve os procedimentos de campo que foram seguidos para cada estudo de caso: 
a) Tendo sido definida a amostra, coube à entrevistadora buscar conhecer as empresas através de sites e demais recursos de mídia, como reportagens em revistas e jornais eletrônicos. Esta análise serviu como recurso facilitador para a entrevistadora na primeira abordagem à empresa, feita por telefone, onde buscou-se conhecer o executivo, apresentar o projeto de pesquisa e marcar a entrevista;

b) Em todos os casos da fase 1, foi entrevistado o executivo diretamente ligado aos negócios com a Petrobras, dando preferência aos cargos de maior nível hierárquico (presidente ou diretor);

c) Em todos os casos da fase 2, além do executivo, optou-se por entrevistar dois ou mais engenheiros diretamente envolvidos em cada projeto, obtendo-se sucesso em todos os casos;

d) Todas as entrevistas obedeceram ao mesmo roteiro, sendo roteiro 1 para a fase 1 , e roteiro 2 para a fase 2 , de forma a equacionar os resultados buscados nas entrevistas.

Algumas observações in loco e/ou interações informais foram descritas com intuito de apresentar características da estrutura técnico/gerencial das empresas visitadas, porém não foram analisadas com o rigor do roteiro, compondo apenas dados secundários de análise ${ }^{4}$.

\subsection{SÍNTESE}

O quadro 8 resume a metodologia e os procedimentos adotados para 0 desencadeamento desta pesquisa.

\footnotetext{
${ }^{4}$ Compreende-se por dados secundários todos aqueles não estabelecidos no roteiro de pesquisa.
} 


\section{METODOLOGIA E PROCEDIMENTOS}

\section{$\rightarrow$ QUESTÃO DA PESQUISA}

Como se dá a construção das capacitações dinâmicas nas empresas de serviços de engenharia, a partir das exigências cadastrais e contratuais do seu principal cliente: a

Petrobras?

\section{గ}

\section{PROPOSIÇÃO 1}

Dada às exigências cadastrais e contratuais da Petrobras, as empresas de serviços de engenharia são obrigadas a proceder com mudanças técnicas, organizacionais e estruturais para se adequarem ao perfil dos fornecedores da contratante.

PROPOSIÇÃO 1
Dada às exigências cadastrais e
contratuais da Petrobras, as
empresas de serviços de engenharia
são obrigadas a proceder com
mudanças técnicas, organizacionais
e estruturais para se adequarem ao
perfil dos fornecedores da
contratante.

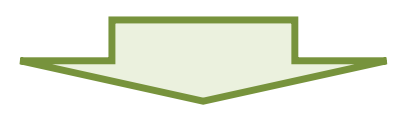

\section{PROJETO DE PESQUISA}

\section{PROPOSIÇÃO 2}

As experiências obtidas através dos projetos executados para a Petrobras são as principais fontes para a criação das capacitações dinâmicas pelas empresas de serviços de engenharia em foco, considerando a aprendizagem e a absorção do conhecimento obtido.
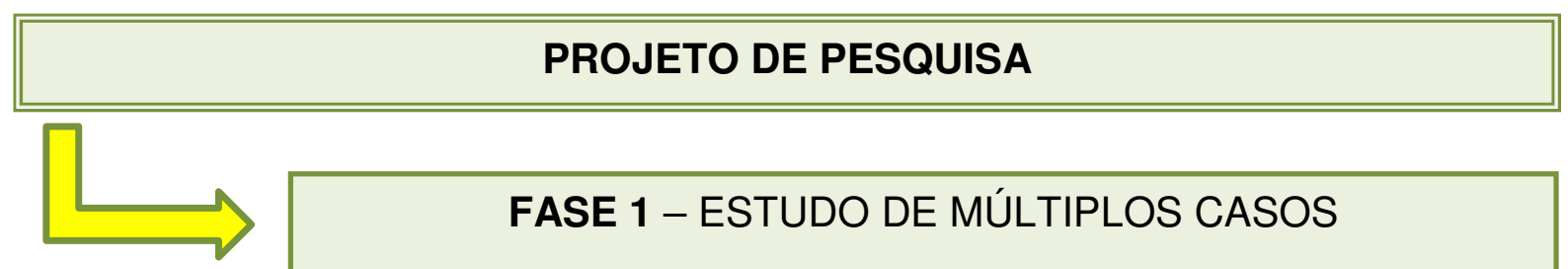

\section{FASE 1 - ESTUDO DE MÚLTIPLOS CASOS}

Características gerais das empresas de serviços de engenharia

Abordagem em 14 empresas

$\checkmark$ Roteiro pré-determinado
FASE 2 - ESTUDO DE MÚLTIPLOS CASOS
$\checkmark$ Criação de capacitações dinâmicas nas empresas de serviços de engenharia
$\checkmark$ Abordagem em 3 empresas
$\checkmark$ Roteiro pré-determinado
$\checkmark$ Análise de indicadores de capacitação 


\section{PESQUISA DE CAMPO - FASE 1}

Para Marconi e Lakatos (2006), pesquisa de campo é aquela utilizada com o objetivo de se obter informações e conhecimentos acerca de um problema para o qual se procura uma resposta, ou de uma hipótese ou proposição que se queira comprovar, ou ainda, descobrir novos fenômenos e as relações entre eles.

É nesse contexto que a pesquisa de campo será utilizada para a realização das duas fases da pesquisa, conforme descrito no capítulo 3 .

A primeira fase teve como objetivo a coleta de informações gerais da interação da Petrobras com as empresas de serviços de engenharia.

$\mathrm{Na}$ sequência, serão descritos os estudos de caso, considerando a primeira etapa da pesquisa.

\subsection{ESTUDOS DE CASO FASE 1: RELAÇÃO PETROBRAS versus EMPRESAS DE SERVIÇOS DE ENGENHARIA}

Os estudos de caso da fase 1, que contaram com 14 empresas, foram realizados com o objetivo de coletar informações gerais da interação da Petrobras com as empresas de serviços de engenharia. Vale ressaltar que, por motivo de confidencialidade, os nomes das empresas são fictícios.

Foram realizados 8 estudos de caso com levantamento in loco - entrevistas, análise de documentos e, muitas vezes, contatos posteriores por telefone ou e-mail. Diante da convergência observada nas empresas optou-se, conforme preceito de Eisenhardt (1989), por ampliar a abrangência do levantamento nas 6 empresas restantes através de contatos telefônicos, teleconferências e e-mail. 
Em todos os casos procurou-se entrevistar o executivo diretamente ligado aos negócios com a Petrobras, ou o profissional por ele indicado. Os cargos dos entrevistados serão descritos na tabela 1.

Tabela 1 - Relação de empresas, cargos e dados das entrevistas

\begin{tabular}{|c|c|c|c|}
\hline EMPRESA & CARGO & ENTREVISTA & DURAÇÃO (horas) \\
\hline CNC & Gerente de Óleo \& Gás & Presencial & $3: 25$ \\
\hline$E G X$ & Diretor de Óleo \& Gás & Presencial & $2: 20$ \\
\hline GPR & Gerente de Desenvolvimento de Negócios & Presencial & $2: 30$ \\
\hline IMC & Diretor Executivo & Presencial & $1: 45$ \\
\hline JPT & Diretor Executivo & E-mail / Telefone & $-{ }^{*}-$ \\
\hline KAT & Gerente de Processo & Presencial & 3:00 \\
\hline$O D B$ & Gerente Comercial & E-mail / Telefone & $-{ }^{*}-$ \\
\hline PJC & Gerente de Instrumentação e Elétrica & Presencial & 2:08 \\
\hline PRO & Diretor de Negócios & Presencial & $1: 30$ \\
\hline$B Y N$ & Diretor Executivo & E-mail / Telefone & $-{ }^{*}-$ \\
\hline GRT & Diretor Executivo & E-mail / Telefone & $-{ }^{*}-$ \\
\hline IEZ & Presidente & E-mail / Telefone & $-{ }^{*}-$ \\
\hline PGN & Gerente Comercial & Presencial & $2: 17$ \\
\hline SEE & Diretor de Sistemas & E-mail / Telefone & $-{ }_{-}^{*}$ \\
\hline \multicolumn{3}{|c|}{ TOTAL DE HORAS PRESENCIAIS ${ }^{5}$} & $18: 55^{\prime}$ \\
\hline
\end{tabular}

Fonte: Autora

Conforme citado, o roteiro visou à coleta de dados gerais sobre os impactos dos contratos da Petrobras nas empresas de serviços de engenharia.

Foram questionadas características da evolução das empresas em decorrência da interação com a Petrobras, onde se buscou verificar informações como: tempo de

\footnotetext{
${ }^{5}$ A quantidade total de horas compreende o tempo demandado para a realização das entrevistas presenciais, não estando incluso o tempo gasto com deslocamentos ou pesquisas em mídia.
} 
relação, exigências da Petrobras para inserção da empresa em seu cadastro de fornecedores, detalhes sobre o ganho de contratos, mudança estrutural em decorrência dos contratos (ou do cadastro), a aprendizagem decorrida das interações, e outras informações acerca das relações contratuais.

Após a análise conjunta dos casos, os próximos tópicos serão dedicados à explicitação das informações coletadas nas empresas, o que nos trará um breve cenário do papel da Petrobras nas empresas de serviços de engenharia entrevistadas.

\subsubsection{Fator: início da relação com a Petrobras}

Conhecer o tempo da relação das empresas entrevistadas com a Petrobras teve por objetivo obter informações que pudessem nos remeter a dois diagnósticos: a solidez da relação entre as empresas e uma possível mudança estrutural decorrente dos contratos, em comparação a data atual, conforme poderá ser visto no tópico 5.1.5. 
Tabela 2 - Ano do primeiro contrato com a Petrobras

\begin{tabular}{c|c}
\hline EMPRESA & ANO DO PRIMEIRO CONTRATO \\
\hline CNC & 2002 \\
EGX & 2000 \\
GPR & 2000 \\
IMC & 2005 \\
JPT & 1997 \\
KAT & 2004 \\
ODB & 1964 \\
PJC & 2004 \\
PRO & 1960 \\
BYN & 1997 \\
GRT & 1980 \\
IEZ & 2005 \\
PGN & 1994 \\
SEE & 1980 \\
\hline
\end{tabular}

Fonte: Pesquisa de campo. Elaborada pela autora.

\subsubsection{Fator: exigências contratuais}

Quanto às principais exigências, ou requisitos, da Petrobras para que as empresas de serviços de engenharia estejam aptas a participar das concorrências ou licitações, foi unânime entre as empresas que pertencer ao cadastro de fornecedores da Petrobras, sem restrições, é a primeira grande exigência. $\mathrm{Na}$ sequência, manter os produtos e serviços aprovados no vendor-list (lista de fornecedores), considerando o alto grau de exigência da Petrobras, é relatado como outra grande vitória.

Outros fatores citados pelos entrevistados foram: o histórico da relação da empresa com a Petrobras, a solidez da empresa e a tríplice qualificação (ISO 9.001, ISO 14.001 e OHSAS 18.001), que demonstra compromisso com a qualidade, se segurança e meio ambiente. 


\subsubsection{Fator: cadastro}

Tornar-se fornecedora da Petrobras implica inicialmente, conforme citado nas entrevistas, vencer um grande desafio: atender ás exigências cadastrais da Petrobras. Variáveis como tradição, experiência, situação econômico-financeira, aspectos gerenciais e outros, são alguns pontos de análise da primeira fase do cadastramento.

O sistema de cadastramento da Petrobras, conforme citaram os entrevistados, é o sistema de qualificação de fornecedores para serviços de engenharia mais robusto e exigente já visto. Vale ressaltar que estar inserido no sistema de cadastro da Petrobras é o primeiro critério possivelmente qualificador para que as empresas de serviços de engenharia estejam aptas a disputar o fornecimento de serviços.

A fase inicial do cadastramento se dá via portal on-line da Petrobras, onde a empresa interessada solicita a abertura do cadastro. A Petrobras, de posse da solicitação, permite o acesso da empresa ao portal durante 45 dias, período este considerado pela Petrobras como suficiente para que a empresa reúna todas as informações e documentos necessários.

Os itens investigados inicialmente pela Petrobras referem-se à tradição e experiência das empresas de engenharia, considerando 0 objeto ${ }^{6}$ pelo qual está sendo solicitado o cadastro. Na sequência, itens como situação econômicofinanceira, aspectos gerenciais, SMS (saúde, segurança e meio ambiente), entre outros, também são julgados. No caso da SMS, por exemplo, até as instalações físicas da empresa são verificadas: número de pessoas por $\mathrm{m}^{2}$, relação de pessoas versus número de máquinas e equipamentos, disponibilidade para alocação de equipe da Petrobras, etc.

Cada tópico é investigado em detalhes e considera as particularidades do que se deseja oferecer à Petrobras. Para as empresas de serviços de engenharia, por

\footnotetext{
${ }^{6}$ No cadastro, denomina-se "objeto" o tipo de produto/serviços a ser fornecido pela empresa que solicita a abertura do cadastro. Neste caso, o objeto é o "serviço" a ser prestado.
} 
exemplo, solicita-se que sejam cadastrados todos os softwares dos quais a empresa possui licença.

Após esta primeira fase a Petrobras analisa todos os itens pré-cadastrados e sugere os ajustes que considera necessário. Sendo atendidos todos os ajustes sugeridos, o cadastro é aprovado por seis meses, passando a ser atualizado anualmente após este período.

Para cada item de serviços no qual a empresa se cadastrou, a Petrobras atribui inicialmente o conceito " $\mathrm{C}$ " em seu Boletim de Avaliação de Desempenho - BAD. Na medida em que a empresa de engenharia passa a fornecer os serviços, estes podem ter a classificação alterada para B ou C (sendo A melhor que B), de acordo com o julgamento dos fiscais da Petrobras que vistoriam os serviços já executados pela empresa contratada.

A Petrobras fiscaliza os seus fornecedores, continuamente, através de fiscais internos e auditorias externas (como a Fundação Vanzolini ou o Bureau Veritas). A auditoria tem como função verificar e relatar qualquer não conformidade encontrada na empresa fornecedora, cabendo à Petrobras acompanhar o seu desempenho nos quesitos contratuais. Novamente a Petrobras pode sugerir melhorias, cabendo a cada empresa implementá-las ou não, sob pena de desclassificação para futuros fornecimentos.

Estar cadastrada na Petrobras significa estar habilitado a pertencer ao "vendor-lisf', ou seja, relação de empresas aptas a participar de uma dada licitação. As licitações de porte chegam, por exemplo, a especificar qual o tipo de software a empresa de engenharia precisa trabalhar para que seja considerada apta a integrar o vendor-list de um dado projeto (por isso a necessidade de cadastramento de softwares no início do preenchimento do cadastro). Embora cheia de detalhes e com alto rigor técnico, as licitações são consideradas muito bem preparadas e consistentes no que tange a qualidade das informações prestadas ao fornecedor.

O sistema de cadastramento de fornecedores da Petrobras parece ser efetivamente engenhoso e bem montado, tendo sido considerado pelas empresas de serviços de 
engenharia o mais bem estruturado sistema de qualificação de fornecedores, dada sua exigência e consistência de informações.

Diante deste cenário, podemos tirar duas conclusões: a primeira diz respeito às altivas exigências da Petrobras com as empresas fornecedoras de serviços de engenharia, desde a fase de cadastramento; a segunda nos mostra que, mesmo diante de tantas exigências, as empresas empenham-se em atender tais quesitos como forma de manter-se no cadastro, mesmo que isto exija mudança na própria cultura da empresa ou, ainda, o aumento dos dispêndios internos para adquirir as capacitações técnico/estruturais necessárias.

\subsubsection{Fator: contratos}

O ganho dos contratos com a Petrobras foi atribuído ao fator preço em primeiro lugar. Na sequência foi citada a capacitação técnica e o conceito obtido pela empresa de engenharia no Boletim de Avaliação de Desempenho - BAD - cujo conceito é atribuído pela Petrobras após a fiscalização dos projetos já executados pela empresa contratada.

Quanto ao BAD, o ideal é que a empresa esteja cadastrada com bom índice (sendo " $A$ " melhor que "B"), pois pode ocorrer que num dado projeto a área de qualificação da Petrobras solicite fornecedores somente com conceito "A".

Para projetos de porte a Petrobras também realiza uma análise financeira da empresa, já que o cadastro traz dados do balanço dos três últimos anos das empresas fornecedoras. Este passa, então, a ser outro crivo para o ganho de contratos, pois, pode haver a necessidade das empresas apresentarem garantias bancárias e seguro do projeto.

O cadastro da Petrobras exige muito além de documentos e certidões legais; é exigido, também, currículo do corpo gerencial e diretor, procedimentos de gerenciamento, procedimento de controle de projetos, entre outros. Quanto às 
certificações, a tríplice qualificação (ISO 9.001, ISO 14.001, OHSAS 18.001) é quesito básico para que se possa participar das licitações, pois a Petrobras preza, e muito, o fator qualidade.

\subsubsection{Fator: mudança estrutural}

Quanto a uma possível mudança estrutural na empresa em decorrência dos contratos com a Petrobras, as empresas entrevistadas, sem exceção, admitem ter crescido a partir do ganho de contratos.

Para atender a Petrobras, as empresas se viram diante do desafio de promover uma reestruturação interna e adotar novas formas e padrões de trabalho. Algumas empresas criaram departamentos específicos de engenharias (civil, elétrica, tubulação, etc.), contrataram mão-de-obra específica, como projetistas e desenhistas, atualizaram ou criaram o departamento de Tecnologia da Informação $\mathrm{TI}$ - para desenvolver ou capacitar pessoas a utilizarem softwares específicos de engenharia ou da própria Petrobras. Em muitos casos, houve a necessidade de mudança na própria cultura da empresa, que determinaria conceitos mais voltados às questões da qualidade.

Um fato que merece destaque foi relatado pela empresa KAT que, para atender a todas as normas de qualidade da Petrobras, viu-se obrigada a desativar o seu prédio sede que, por ser antigo, não possuía um sistema de tubulação de ar-condicionado condizente com as normas atuais de segurança. Porém, mesmo com todas as dificuldades enfrentadas, o entrevistado disse concordar com a sistemática rígida da Petrobras. 


\subsubsection{Fator: terceirização}

A preocupação em atender bem a Petrobras é constante para as empresas de engenharia. Esta preocupação extrapola os limites das empresas que contratam mão-de-obra indireta para determinados projetos. Assim como a Petrobras tem suas exigências quanto à qualidade na execução dos projetos, as empresas de engenharia exigem dos subcontratados o mesmo comprometimento na execução das suas atividades. Normalmente, a subcontratação pelas empresas de engenharia se dá em obras de construção civil.

\subsubsection{Fator: aprendizado}

Quando perguntado aos entrevistados sobre qual seria o maior aprendizado diante da relação de parceria, através do ganho de contratos, das empresas de serviços de engenharia com a Petrobras, a constante busca pela excelência foi um dos aprendizados mais citados.

As empresas consideram que, sendo a Petrobras uma empresa de referência mundial, a busca pelo aprendizado contínuo, o aumento da capacitação de pessoal e a melhoria contínua da qualidade e produtividade das empresas de engenharia, visando produtos e processos mais seguros ao ser humano e menos agressivos ao meio ambiente, as farão crescer e obter reconhecimento internacional, como já vem ocorrendo em alguns casos relatados nas entrevistas.

Além disso, foi citado o constante aprendizado tecnológico, pois a Petrobras trabalha com tecnologia de ponta, com softwares específicos, unindo sempre novos conceitos às suas atividades. 


\subsubsection{Fator: presente e futuro}

Para manter-se no cadastro da Petrobras e, desta forma, continuar alavancando novos negócios, as empresas demonstraram preocupação de sempre melhorar os serviços prestados, aumentando sua qualidade, capacitação técnica e competência profissional, criando novos padrões de trabalho que permitam minimizar qualquer risco de erro nos projetos.

Além disso, várias empresas relataram estar contratando jovens talentos com intuito de treiná-los para atuarem futuramente em projetos da Petrobras.

Há, também, grande expectativa das empresas de serviços de engenharia quanto ao pré-sal e ao avanço em geral do setor de óleo e gás, que promoverá inúmeros novos projetos na Petrobras e, sendo esta responsável por grande parte do faturamento das empresas entrevistadas, espera-se que o crescimento ocorra em cadeia.

Dentre os objetivos futuros, destacamos a intenção da empresa EGX em criar uma fábrica para atender especificamente a Petrobras. Esta fábrica seria responsável pela produção de cascos, sondas, vasos de pressão, tanques de armazenamento e outros produtos considerados "customizados" frente à especificidade de suas características. Para isso, a empresa já está desenvolvendo as capacitações necessárias.

Outra expectativa refere-se à engenharia básica naval para petróleo no Brasil, pois segundo os entrevistados, a Petrobras tem estimulado, através de desafios tecnológicos que coloca aos fornecedores, o desenvolvimento de produtos como, por exemplo, sondas de amarração que se estabilizem por propulsão sem estarem atadas ao solo. Esta e outras propostas impulsionarão as empresas a estudar outras possibilidades de mercado num futuro próximo. 


\subsubsection{Fator: receita}

Outro fator que merece destaque é o alto percentual de faturamento nas empresas, cuja origem deriva de projetos com a Petrobras. Diante deste fato, fica claro que estas empresas dependem, em grande parte, da relação de parceria com a Petrobras através do ganho de contratos, seja diretamente com a estatal, seja através da contratação de serviços por uma empresa epecista.

Tabela 3 - Porcentagem de faturamento com projetos da Petrobras

\begin{tabular}{c|c}
\hline EMPRESA & $\begin{array}{c}\text { \% DE FATURAMENTO COM } \\
\text { PROJETOS PETROBRÁS }\end{array}$ \\
\hline CNC & 37 \\
EGX & 77 \\
GPR & 65 \\
IMC & 100 \\
JPT & 95 \\
KAT & 90 \\
ODB & 85 \\
PJC & 80 \\
PRO & 75 \\
BYN & 50 \\
GRT & 60 \\
IEZ & 90 \\
PGN & 16 \\
SEE & 60 \\
\hline
\end{tabular}

Fonte: Pesquisa de campo. Elaborada pela autora.

\subsection{SÍNTESE}

O primeiro fator que merece destaque, frente às informações obtidas em campo nesta primeira fase da pesquisa, é o alto percentual de faturamento das empresas de engenharia relacionado aos contratos com a Petrobras. Os executivos 
entrevistados também relacionam a composição deste faturamento ao aumento do quadro de funcionários da estrutura física das empresas.

O gráfico 5 permite melhor visualização do grau de dependência das .empresas ao faturamento dedicado a projetos com a Petrobras.

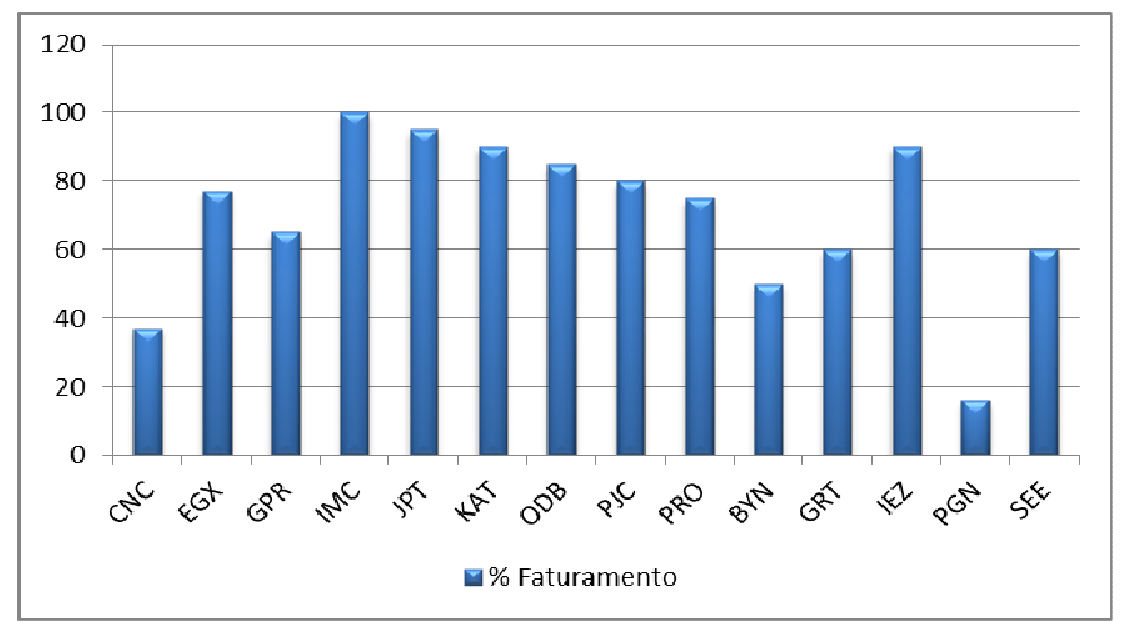

Gráfico 5 - Porcentagem de faturamento com projetos Petrobras Fonte: Pesquisa de campo. Elaborado pela autora

As entrevistas mostraram, também, que as exigências de capacitação tecnológica e gerencial para a disputa de contratos com a Petrobras são muito maiores do que as feitas por outros clientes, o que Ihes atribui certo atestado de competência técnico/gerencial.

Para atender aos requisitos cadastrais e contratuais, as empresas entrevistadas relatam que se viram diante do desafio de promover uma reestruturação interna, adotando novas formas de trabalho e novos procedimentos ligados a qualidade dos serviços prestados, criando departamentos específicos para cada disciplina de engenharia (elétrica, civil, mecânica, instrumentação, tubulação, etc.).

Além disso, a força de trabalho passou, em todos os casos, por uma transformação no que tange à especialização exigida pela Petrobras para contratos de ponta; gerentes, projetistas, desenhistas, e pessoal ligado á área de TI (Tecnologia da Informação), viram-se obrigados a investir em sua qualificação para atender aos requisitos mínimos necessários à integração das equipes de projetos da Petrobras. 
Quanto à área de TI, especificamente, foi citado que houve grandes mudanças na sua cultura, agora muito mais voltada à preparação dos profissionais para atuarem em softwares específicos de engenharia ou da própria Petrobras.

Sendo a Petrobras uma empresa de referência mundial, a busca pelo aprendizado contínuo, seja investindo em cursos de capacitação dos funcionários, seja investindo na absorção do conhecimento advindo na atuação nos contratos e nas experiências agregadas com cada projeto, fazem com que as empresas de serviços de engenharia que atuam com a Petrobras tenham maior notabilidade nos cenários nacional e internacional, frente às empresas que não atuam com ela.

Sem exceção, os entrevistados concordam que a relação com a Petrobras e a experiência obtida nos contratos, bem como o conhecimento absorvido em cada projeto, são pontes para a atuação em outros clientes, nacionais e internacionais, visto a confiabilidade que é depositada às empresas que estejam aptas a atender as exigências da Petrobras em seu cadastro e em seus contratos.

Manter-se no cadastro da Petrobras é o mesmo que buscar a excelência ininterruptamente. Ser fornecedor da Petrobras pré-estabelece normas de conduta profissional, atualizações técnicas frequentes, responsabilidade e compromissos contratuais e, muitas vezes, uma mudança na própria cultura empresarial, mais voltada às áreas de saúde, segurança e meio-ambiente.

Todos os entrevistados concordam que a relação de parceria e a experiência obtida através dos projetos da Petrobras são fatores qualificadores e ganhadores de pedidos junto a outros clientes e/ou mercados.

As empresas consideram que ter a Petrobras como cliente é um "cartão de visitas", pois a Petrobras é vista no mercado como um padrão de referência quanto às normas de trabalho exigidas aos seus parceiros. Portanto, as empresas que estão aptas a atendê-la demonstram confiabilidade e têm papel de destaque no mercado frente às demais. 
Os resultados mostraram que possuir capacitação para ser cadastrado como fornecedor da Petrobras é o ponto mais relevante da relação. Deste resultado derivou-se a segunda fase da pesquisa, cujo objetivo foi analisar pontos específicos acerca desta capacitação.

Tem-se então um breve cenário da situação das empresas de serviços de engenharia, que se veem diante do desafio de aumentar suas capacitações através da busca por novos conhecimentos e competências.

Tendo sido apresentadas as principais conclusões obtidas no projeto, descritas pontualmente apenas com intuito de reforçar o que motivou a elaboração de um novo trabalho de pesquisa, dar-se-á sequência a contextualização do tema escolhido, bem como sua justificativa. 


\section{PESQUISA DE CAMPO - FASE 2}

Conforme descrito no capítulo 3, a pesquisa de campo deu-se em duas fases, com abordagens distintas. Tendo sido apresentada a primeira fase, que buscou coletar dados gerais das interações da Petrobras com as empresas de serviços de engenharia, dar-se-á sequência à apresentação da segunda fase.

Considerando o objetivo da pesquisa, que visa analisar como são criadas as capacitações dinâmicas das empresas de serviços de engenharia, esta fase capta informações acerca das principais atividades que vem sendo agregadas pela empresa para a execução dos projetos em parceria com a Petrobras. Para tanto, tomou-se três projetos executados em diferentes datas e fez-se um levantamento de como a empresa se estruturou e organizou para atender aos requisitos contratuais da Petrobras em cada projeto. Esta atividade visa efetuar um comparativo entre os projetos no que tange o número de pessoal envolvido, as rotinas e procedimentos adotados, os softwares utilizados, entre outros.

Nesta fase buscou-se também obter informações sobre como o conhecimento é absorvido através da aprendizagem decorrida dos projetos e, ainda, como este conhecimento é codificado na empresa para posterior disseminação.

Na sequência serão descritos os estudos de caso realizados em três empresas de serviços de engenharia.

\subsection{ESTUDOS DE CASO FASE 2: CRIAÇÃO DAS CAPACITAÇÕES DINÂMICAS NAS EMPRESAS DE SERVIÇOS DE ENGENHARIA}

Conforme descrito no capítulo 3, para o desenvolvimento da pesquisa de campo na segunda fase, foram selecionadas três empresas de serviços de engenharia: CNC, GPR e KAT. A escolha foi feita com base na disponibilidade dos executivos e 
engenheiros a participar do novo levantamento de dados, já que esta fase previa mais de um respondente e maior tempo de abordagem.

O roteiro utilizado foi construído com base em dois objetivos:

- Como primeiro objetivo, visou-se o aprofundamento das informações acerca da relação das empresas de serviços de engenharia com a Petrobras quanto às práticas adotadas para a criação das rotinas, quanto à questão das competências técnicas da empresa e, principalmente, quanto à preparação das empresas para atender aos requisitos cadastrais e contratuais da Petrobras.

- Como segundo objetivo, propôs-se analisar três projetos em cada uma das empresas, cuja finalidade foi verificar o acúmulo das capacitações no decorrer deles. Para tanto, tomou-se por base três projetos executados em diferentes datas e fez-se um levantamento de como a empresa se estruturou e organizou para atender aos requisitos contratuais da Petrobras em cada um deles. Esta atividade visou efetuar um comparativo entre os projetos para demonstrar a evolução de algumas capacitações: o número de mão-de-obra especializada (engenheiros) envolvida, o número de rotinas e procedimentos adotados, os softwares utilizados e as alianças estratégicas formadas em função dos projetos.

Considerando o objetivo geral desta pesquisa, que visa verificar como são criadas as capacitações dinâmicas das empresas de serviços de engenharia, o roteiro criado para a segunda fase visa captar informações acerca das principais capacitações que vem sendo agregadas pelas empresas para a execução dos projetos, tendo em vista o papel indutor da Petrobras.

O roteiro na íntegra, bem como a planilha elaborada para a coleta de dados dos projetos, poderão ser conferidos no apêndice 2. 


\subsection{APRESENTAÇÃO DA EMPRESA CNC}

A CNC acumula ampla experiência na prestação de serviços de consultoria, no gerenciamento de projetos e em soluções completas de engenharia, que abrangem desde os estudos de viabilidade até o início da operação do empreendimento. Com mais de 1000 estudos e serviços de engenharia realizados ao longo dessa trajetória, a CNC ergueu diversos complexos hidrelétricos e termelétricos, metrôs, portos, aeroportos, rodovias, ferrovias, obras de saneamento básico, plantas industriais de refino e distribuição de óleo e gás e petroquímicas em todo o Brasil e em países da América Latina e da África. Tudo isso é consequência da busca permanente pela inovação e da aposta na qualidade por meio da capacitação.

A empresa conta hoje com mais de 700 profissionais diretos, com habilidades multidisciplinares, em sua maioria com nível superior e pós-graduação. Conta também com mão de obra terceirizada, que pode dobrar o seu efetivo dependendo da carteira de projetos.

Devido à facilidade de acesso, a empresa CNC foi escolhida para a realização do teste do roteiro, iniciando assim a abordagem da segunda fase da pesquisa de campo. 


\begin{tabular}{|c|c|c|c|}
\hline EMPRESA & $\begin{array}{c}\text { DATA DA } \\
\text { EMTREVISTA } \\
\end{array}$ & PARTICIPANTE & $\begin{array}{l}\text { DURAÇAO } \\
\text { (HORAS) }\end{array}$ \\
\hline \multirow{10}{*}{$\mathrm{CNC}$} & 18/02/2011(*) & Gerente de Automação & $4: 15$ \\
\hline & 11/03/2011 & Gerente de Automação & 0:35 \\
\hline & 25/03/2011(**) & Gerente de Automação & $2: 40$ \\
\hline & 08/04/2011 & Gerente de Automação & $0: 17$ \\
\hline & \multirow[t]{2}{*}{$29 / 04 / 2011$} & Gerente de Automação & \multirow[t]{2}{*}{ 3:34 } \\
\hline & & Gerente de Negócios & \\
\hline & \multirow[t]{4}{*}{ 23/09/2011 } & Gerente de Automação & \multirow[t]{3}{*}{ 3:15 } \\
\hline & & Engenheiro de Instrumentação & \\
\hline & & Engenheiro Eletricista & \\
\hline & & TEMPO TOTAL & 14hs31 \\
\hline
\end{tabular}

A primeira entrevista (18/02/2011) foi realizada com base no roteiro previamente preparado pela autora. Durante sua aplicação, foram levantadas algumas falhas e sugestões, o que motivou a readequação do roteiro.

A segunda entrevista (25/03/2011) visou aplicar o roteiro (apêndice 2) considerando seus ajustes, onde foi constatado que a presença do Gerente de Negócios membro mais próximo da relação com a Petrobras - seria imprescindível para o sucesso da entrevista. Desta forma, uma nova entrevista foi marcada.

A terceira entrevista (29/04/2011) contou com a participação do Gerente de Negócios, conforme sugerido pelo Gerente de Automação. Considera-se que o objetivo fora alcançado nesta entrevista.

Após visitar outras duas empresas, que compõem a segunda fase da pesquisa, julgou-se conveniente retornar à empresa para replicação de algumas perguntas e coleta de maiores detalhes, cuja importância apareceu no decorrer dos trabalhos de abordagem em campo. Com base neste argumento, foi feita a quarta e última entrevista na empresa CNC. 
A seguir, serão descritas algumas informações sobre a abordagem na empresa CNC.

\subsubsection{Relação CNC / PETROBRAS}

A CNC teve seu primeiro grande contrato com a Petrobras em 2002, através da subcontratação dos seus serviços por uma empresa epecista, detentora do poder de execução e coordenação total de um dado projeto.

Os próximos tópicos serão dedicados a descrever como se dá a preparação da CNC para atender a Petrobras, considerando seu papel indutivo na criação das capacitações pelos seus fornecedores.

6.2.1.1 CNC e a mudança na estrutura da empresa

Segundo os entrevistados, a CNC cresceu muito a partir do ganho de contratos com a Petrobras, seja através de contratação direta, seja através da contratação dos seus serviços por uma empresa epecista. O número de pessoal contratado aumentou significativamente, assim como as contratações de mão-de-obra terceirizada e de serviços de consultoria.

Um novo escritório foi aberto no Rio de Janeiro para atender a uma possível exigência da Petrobras, que já sinalizou aos seus fornecedores de serviços de engenharia a necessidade de maior proximidade com o CENPES.

Trabalhar com a Petrobras também resultou na reestruturação do Departamento de $\mathrm{TI}$, uma vez identificado que hardwares e softwares de última geração são pontos chave para a modelagem dos projetos da Petrobras. Além da compra das licenças para utilização de softwares que atendem a necessidade da modelagem tridimensional - integrando três disciplinas da engenharia: elétrica, tubulação e 
instrumentação - houve a reestruturação dos recursos humanos dedicados ao departamento, mais voltado a especialista da área de informática, como design de software, arquiteto de redes, técnico de manutenção em máquinas, servidores e redes, etc.

Ainda visando melhorar a atuação com a Petrobras, uma nova forma de trabalho foi adotada pela CNC, cujo objetivo principal visa aumentar a confiabilidade na prestação de contas de cada projeto de porte.

Atualmente, a cada novo projeto de porte, ocorre segregação de pessoal, máquinas e equipamentos para que se tenha o controle total e minucioso dos custos do projeto. A equipe que atuará no projeto - Equipe Tarefa - é alocada para uma estrutura física totalmente independente das demais áreas da empresa, onde todo o trabalho desenvolvido (custos homem/hora), despesas com máquinas e equipamentos, telefone, luz, aluguel, licença para utilização de softwares, etc., são contabilizados como custo real do projeto.

Esta prática, segundo o Gerente de Negócios, além de melhorar a organização dos trabalhos, torna a contabilidade dos custos do projeto mais clara, onde todas as despesas podem ser controladas e descontadas das contas daquele projeto, dando maior confiabilidade tanto para a CNC quanto para a Petrobras, principalmente no caso de haver necessidade de cobrança de um aditivo contratual. Ao final, sabe-se qual foi o total dos custos, das despesas e do lucro.

Ter contratos com a Petrobras e adotar esta prática para atender aos projetos de porte, também possibilitou à CNC ganhar contratos com grandes empresas privadas como, por exemplo, Basf, Vale, Votorantim, entre outras. Muitas empresas privadas costumam visitar as instalações da empresa de serviços de engenharia antes da sua contratação para grandes projetos. "Neste caso, a experiência com a Petrobras faz a diferença em função da estrutura da empresa, da especialização dos funcionários, do domínio nos principais softwares de engenharia e da própria experiência com projetos de porte" (Gerente de Negócios). 
A CNC também revisou seus processos-chave e implementou um Sistema Integrado de Gestão, unificando Qualidade, Saúde e Segurança no Trabalho e Meio Ambiente, o que resultou na conquista, no final de 2007, da Tríplice Certificação, conferida pela Fundação Carlos Alberto Vanzolini, nas normas ISO 9001:2000, ISO 14001:2004 e OHSAS 18001:1999.

\subsubsection{CNC e a competência técnica}

Desde 2002, quando ganhou o seu primeiro grande contrato com a Petrobras, a CNC vem investindo em competência técnica especialista. Para o Gerente de Negócios esta é, sem dúvida, a maior exigência que a Petrobras faz aos seus fornecedores, depois de vencidas as etapas burocráticas previstas em suas licitações. "A relação de parceria com a Petrobras exige das empresas de serviços de engenharia a busca constante pelo aumento das suas capacitações, focando o aprendizado a cada novo projeto" (Gerente de Negócios).

$\mathrm{Na}$ tentativa de antever as necessidades da Petrobras, no que tange as competências técnicas requeridas das empresas de serviços de engenharia, a CNC passou a realizar uma análise potencial de seus colaboradores através de uma ferramenta chamada "Plano de Desenvolvimento Individual" (PDI). Esta ferramenta permite a empresa gerar um documento cujo objetivo principal é apontar ao empregado o que o mercado está oferecendo em termos de capacitação a curto e médio prazo.

A Petrobras em 2009, por exemplo, sinalizou que estaria trabalhando com o software COMOS e que sua utilização não estaria longe de ser obrigatória. O documento (PDI) sinalizou aos colaboradores que seria bom que se capacitassem neste quesito. Diante deste fato, a CNC criou um grupo composto por engenheiros e projetistas de diferentes disciplinas (elétrica, civil, tubulação, instrumentação, etc.) e os encaminhou para a seleção do $\mathrm{PROMIMP}^{7}$ para a realização do curso. Na

\footnotetext{
${ }^{7}$ PROMIMP: Programa de Mobilização da Indústria Nacional de Petróleo e Gás Natural, coordenado pelo Ministério de Minas e Energia.
} 
sequência, estes profissionais disseminaram o conhecimento adquirido através de cursos internos dados aos demais profissionais das respectivas disciplinas.

Tendo em vista o aumento expressivo dos projetos da Petrobras, o que resulta na demanda por profissionais devidamente qualificados, a empresa aumentou o número de contratações, assim como o investimento em treinamentos específicos para o setor de óleo e gás, como é o caso dos cursos para utilização dos principais softwares utilizados (e muitas vezes exigidos) pela Petrobras - PDMS, COMOS, etc.

Os investimentos vão além e abarcam cursos com diversas empresas fabricantes de equipamentos para instrumentação. Neste caso, o fabricante de equipamentos vem até a CNC promover o curso e demonstrar a aplicabilidade de seus equipamentos.

Há também várias palestras com profissionais especialistas em assuntos como geocronologia, cabeamento, análise de riscos, etc., que são trazidas para a empresa visando complementar o conhecimento necessário para melhor conduzir os projetos da Petrobras.

Ao final de cada projeto realizado junto à Petrobras, a CNC promove uma palestra do gerente do projeto, junto aos seus engenheiros, para relatar as experiências no projeto, deixando sempre claro como se deu a superação das possíveis dificuldades encontradas.

Estas e outras ações, segundo relatou o Gerente de Negócios, são vistas como incentivo ao trabalhador, o que resulta num ambiente mais agradável de trabalho: "a ideia é antecipar a prática de quem está começando a vida profissional e manter as pessoas incentivadas diminuindo, assim, a alta rotatividade, que é bastante comum no setor de serviços de engenharia".

Tanta preocupação com o desenvolvimento das competências internas da empresa deve-se ao fato da Petrobras exigir o currículo de supervisores e de engenheiros para análise prévia e aprovação, de forma que possam integrar a coordenação e/ou a gestão de um dado projeto. 


\subsubsection{CNC e as subcontratações}

Para atender ao escopo dos projetos da Petrobras, cabe à empresa de serviços de engenharia buscar caminhos para a realização de atividades que estejam fora da sua capacitação. Desta forma, sempre que necessário, a CNC contrata mão-de-obra terceirizada e serviços de consultoria para a realização de estudos e análises específicas, cuja competência ainda não tenha sido desenvolvida internamente.

Normalmente, a contratação do serviço de consultoria é feita para projetos de porte, que envolvem grandes riscos e cuja competência determinante está longe de ser corriqueira, conforme considerado pelo Engenheiro de Instrumentação. Porém, a contratação externa não exime a CNC da responsabilidade pela execução e pelo resultado final dos projetos. Desta forma, os serviços terceirizados também devem obedecer aos critérios de competência e confiabilidade ditadas pela Petrobras.

Esta prática requer da empresa de serviço de engenharia total responsabilidade por qualquer serviço prestado à Petrobras, o que reflete em certos padrões de qualidade por parte da subcontratada. Primar pela qualidade e pontualidade são fatores indispensáveis na escolha de um subcontratado pela empresa de engenharia.

É possível perceber que as exigências da Petrobras extrapolam a cadeia de fornecedores diretos, indo além das fronteiras de seu sistema de cadastro.

Na sequência serão descritos os três projetos analisados na CNC, bem como suas particularidades:

6.2.2 Projeto 1 - Execução de usina termelétrica a gás

O projeto 1 da CNC teve início em outubro/2007. Para execução deste projeto, a CNC contou com a participação de 35 engenheiros diretos. 
O objetivo do projeto foi a geração de vapor para a refinaria e a exportação da energia excedente, depois de suprida sua necessidade energética. O estudo de estabilidade de vapor e o estudo de estabilidade elétrica foram muito particulares neste projeto.

O grande desafio do projeto foi integrar três unidades independentes e com funções distintas a uma única subestação elétrica. Um dos entraves foi que não se conhecia o que havia no subsolo da planta. Foi necessário levantar toda a documentação da planta e verificar a confiabilidade dela, ou seja, se tudo o que a planta marcava realmente estava naquele local e que determinados locais estavam realmente livres. A partir dessas sondagens foi executado o projeto de "envelopamento" de subsolo.

Outro desafio é que as três unidades foram montadas bem compactas, em função do espaço da planta, e devido à disponibilidade local. Parte dos equipamentos que fariam parte desta expansão já estavam comprados, o que levou os engenheiros mecânicos e de tubulação a adequar tais equipamentos ao pouco espaço disponível, o que aumentou o nível de dificuldade do projeto.

Para desenvolver o projeto, foi necessário o serviço de consultoria de profissionais e empresas detentoras de vasta experiência:

- Consultoria para o levantamento de balanço térmico.

- Consultoria para análise de risco e de distância segura.

- Consultoria para estudo específico de demanda de energia, visto que o empreendimento previa a exportação de energia excedente.

- Consultoria para estudos de redes interligadas (fluxos de carga) e outros estudos específicos de demanda termelétrica para os sistemas integrados. 
- Consultoria para a tríplice classificação empresarial em sistema de gestão da qualidade (ISO 9.001); de meio ambiente (ISO 14.001); e de saúde e segurança no trabalho (OHSAS 18.001).

Quanto aos softwares utilizados, além dos aplicativos de engenharia e do software INtools, houve a necessidade de trabalhar com o software PDS, que estava além das competências da empresa até aquele momento. Para tanto, foi negociado com o fornecedor do software um treinamento para alguns empregados, de forma que este conhecimento fora disseminado internamente.

- INtools - Software dedicado a projetos de instrumentação que inclui módulos integrados pra os índices de instrumentos, especificações, dados de processo, cálculo, fiação, desenhos de laço, calibração e manutenção. 0 software dispõe de ligações de dados para sistemas externos, incluindo o PDS (Plant Design System), utilizado pela Petrobras.

- PDS (Plant Design System) - Software dedicado à concepção de plantas industriais através da atividade de engenharia multidisciplinar que integra as disciplinas de tubulação, elétrica e instrumentação. $O$ modelo gerado pelo software PDS ilustra a planta em 2D, além de comportar uma ferramenta que permita extrair uma listagem completa de todos os componentes que precisam ser comprados para a planta (tubos, flanges, colunas, equipamentos de automação, componentes elétricos, etc.).

A execução deste projeto rendeu expectativas à CNC que, atualmente, visa o aumento na carteira de clientes no segmento de energia. Esta visão deve-se a capitalização do conhecimento adquirido neste projeto, que exigiu o aumento de competência técnica especialista e conferiu maior experiência em projetos de engenharia elétrica.

A experiência e o sucesso alcançados neste projeto já deram frutos, rendendo à CNC o ganho de um projeto similar na empresa BASF. 


\subsubsection{Projeto 2 - Planta para carteira de gasolina}

O projeto 2 da CNC teve início em junho/2008. Para execução deste projeto, a CNC contou com a participação de 75 engenheiros diretos.

O objetivo do projeto foi a integração de três unidades distintas e separadas a uma única subestação elétrica, que encontrava-se muito longe das unidades de projeto e com muitos problemas de interferência entre as estações. Segundo os entrevistados, o grande problema é que havia muitas curvas no trajeto, o que impossibilitava a colocação de caixas de passagem entre os trechos.

No início a CNC tentou trabalhar com aplicativos de engenharia próprios para sistemas elétricos, porém a complexidade dos cálculos aumentou muito e, com isso, o risco de erros nos cálculos do máximo esforço que poderia ser aplicado aos cabos que passariam pelos trechos. Depois de executado todo o envelopamento dos condutos (concreto) o desastre seria enorme se houvesse erro e tudo seria arrebentado para uma nova alteração de rota.

Para desenvolver o projeto, foi necessário o serviço de consultoria de profissionais e empresas detentoras de vasta experiência:

- Consultoria para estudo do projeto civil: georadar, fundação, estrutura metálica e análise de solo;

- Consultoria para análise das regulamentações e requisitos do projeto;

- Consultoria para a tríplice classificação empresarial em sistema de gestão da qualidade (ISO 9.001); de meio ambiente (ISO 14.001); e de saúde e segurança no trabalho (OHSAS 18.001).

Para não correr tanto risco a CNC buscou o que havia de melhor no mercado e se valeu de alguns softwares para a especificação, dimensão e puxamento dos cabos, além de outras atividades específicas que o projeto exigia devido a sua 
complexidade. Os softwares que passaram a integrar as atividades de engenharia na empresa foram:

- Cable Polling - software que já vinha sendo utilizado no mundo e possuía um nível de confiabilidade muito bom. A exata predição da tensão de cabo de tração seria essencial para o correto dimensionamento dos sistemas de cabo. Este software tornou possível evitar o subdimensionamento.

- PTW Daper - software que auxilia os engenheiros eletricistas na elaboração dos estudos dos sistemas de potência. Este software permite a elaboração dos estudos de demanda de carga, curto circuito, dimensionamento de transformadores e alimentadores, fluxo de carga, queda de tensão, entre outros.

- TecAt - software utilizado para o cálculo do aterramento. Este software realiza a estratificação da resistividade do solo e em seguida o cálculo da resistência da malha, dos potenciais de toque, passo e superfície necessários para malhas de subestações.

- PDMS (Plant Design Management System) - software utilizado para a confecção de projetos com modelagem $3 \mathrm{D}$, unindo as áreas de elétrica, tubulação e instrumentação. Na medida em que são lançadas as informações, o software vai construindo toda a planta e é possível navegar por ela. Para cada característica alterada no projeto, o software realiza e aponta as alterações em toda a planta do projeto, integrando todas as áreas e dando uma visão tridimensional do projeto como um todo. Com ele, tem-se uma fotografia do projeto pronto, do que será construído.

A utilização do PDMS possibilitou eliminar muitas interferências e aumentou a qualidade na execução dos projetos, evitando erros e retrabalhos. Paralelamente, na medida em que o engenheiro faz a codificação e o lançamento dos materiais, o software gera as lista de materiais (tubos, chapas, cabos, equipamentos, etc.) poupando o trabalho que, antes, era feito manualmente. Isso também ajuda a eliminar interferências (vigas passando), erros de cálculo de compras, que 
impactariam o valor final do projeto. É possível ter a visualização completa do que vai ser montado.

A utilização do software PDMS neste projeto foi, pela primeira vez, exigência da Petrobras e trouxe um alto ganho qualitativo. Melhorou-se a execução á medida em que o software diminua a necessidade de retrabalhos, como transcrições erradas, duplicidade de informações a serem preenchidas, etc.

Para este projeto foi feita também uma análise de mercado para verificar o que havia de melhor em questão de material para lubrificação dos cabos, visando diminuir o coeficiente de atrito estático e dinâmico na hora de fazer o puxamento do cabo e garantir o máximo esforço que ele aguentaria (dinamômetro).

De acordo com o Engenheiro Eletricista, foi uma obra bastante robusta, pois o nível de complexidade era muito grande.

\subsubsection{Projeto 3 - FEED para um complexo petroquímico}

O projeto 3 da CNC teve início em fevereiro/2009. Para execução deste projeto, a CNC contou com a participação de 180 engenheiros diretos.

A implantação ou a ampliação de uma unidade industrial, via de regra, conta com três fases: elaboração do projeto básico, elaboração do projeto FEED e execução da obra.

O projeto FEED (Front and Engineering Design) é uma modalidade de projeto adotada pela Petrobras, cujo objetivo é analisar a consistência do projeto básico e estimar o valor do total da obra. Consiste também do pré-detalhamento do projeto executivo.

Cabe ao FEED efetuar um levantamento prévio da média de custos dos projetos. Conhecendo esta média de custo, a Petrobras lança a licitação e declara vencedora 
somente a empresa que apresentar o menor custo, porém dentro do limite FEED, ou seja, para valores propostos fora da faixa limite, a interpretação da Petrobras é de "provável incompatibilidade técnica" (para custos extremamente menores) ou "preço abusivo" (para custos extremamente maiores).

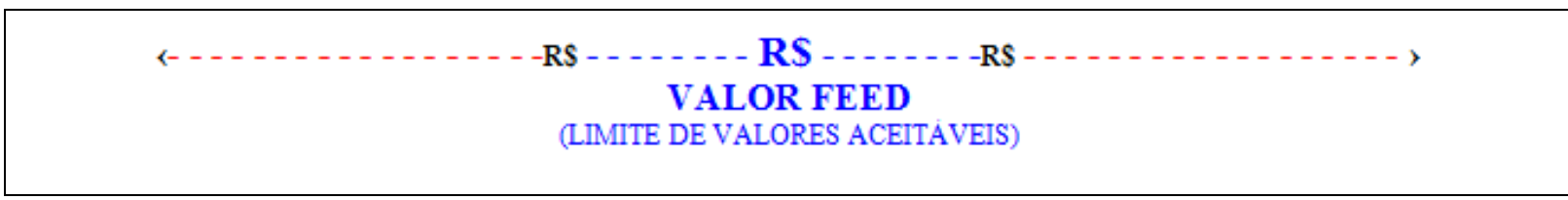

Ilustração 3 - Limite de valores FEED

Fonte: Pesquisa de campo. Elaborado pela autora

Para este caso específico, o projeto FEED teve o seguinte escopo: lista de equipamentos, diagramas, arranjo básico e análise de processo, mas envolvia fortemente subestações e a parte de infraestrutura.

O que mais o difere o projeto FEED dos projetos 1 e 2 é a forma de trabalhar. Por ter o foco no escopo, que não dependia muito da sequência encontrada nos outros projetos (planejamento, processo, disciplinas, desenvolvimento, etc.), o projeto FEED iniciou com uma grande contratação de pessoas, principalmente para a área elétrica, onde cinco supervisores foram contratados, fora os engenheiros de base. Havia muitos documentos e pouco prazo, o que exigia muitos profissionais especialistas.

Este projeto teve o envolvimento mais fortemente de projetos civil e elétrico, além da introdução do software COMOS por exigência da Petrobras.

- COMOS - software dedicado à integração das operações de engenharia e utilizado para o planejamento de uma planta ou instalação, englobando as várias especialidades técnicas, bem como para a configuração do sistema de informações da planta. Todos os equipamentos, tubulações, consumidores, pontos de medição e outros objetos são gerenciados de maneira integrada no COMOS, sendo suas características descritas e interpretadas. 
A empresa WP, que dividia a execução do projeto com a CNC, foi responsável pelo projeto básico, ficando a cargo da CNC a execução do projeto FEED.

Havia muita rigidez no cronograma, muitos documentos para serem analisados e muitas pessoas para serem coordenadas. Além de 180 engenheiros da CNC, três empresas foram contratadas para realização de trabalhos terceirizados no Brasil.

O principal aprendizado, além da elétrica, foi trabalhar com a modelagem 3D com usuários espalhados, quando o convencional é trabalhar em ambiente único. A WP, localizada no exterior, não trabalhava com uma rede onde, por exemplo, o documento principal ficava num servidor e cada usuário podia alterá-lo sem que outros tivessem acesso até o documento ser devolvido ao servidor. A forma de trabalho adotada tinha a seguinte ordem: a WP passava o banco de dados atualizado periodicamente, contendo alterações; na sequência, cabia ao coordenador de cada unidade averiguar o que havia sido alterado em sua unidade específica; por fim, eram feitos os ajustes para incorporar os novos dados no projeto.

Este trabalho foi acompanhado e corrigido ao longo do projeto pela CNC. Tal prática gerou a criação de um procedimento para a utilização do software COMOS, visando padronizar os trabalhos que seriam feitos no futuro. Mais tarde, tais critérios foram refinados e hoje servem de base para trabalhar com todos os projetos com modelagem tridimensional.

Para este projeto não houve a necessidade da contratação de consultoria para a tríplice classificação empresarial em sistema de gestão da qualidade (ISO 9.001, ISO 14.001 e OHSAS 18.001), pois a CNC, detentora das certificações, havia capacitado e especializado pessoal para atender as exigências das normas.

Outro grande aprendizado foi trabalhar com o software COMOS, até então novidade para a empresa. 
O software COMOS, segundo o entrevistado, não chega ao nível de detalhes do software PDMS; ele executa outro trabalho, feito a partir do fluxograma do processo que reúne as áreas de mecânica, tubulação, elétrica e instrumentação.

Para cada elemento acrescido, o software verifica seus parâmetros próprios e sugere que outras características sejam apontadas para este elemento. Por exemplo: quando o elemento acrescido é uma "bomba", o software questiona se a bomba é mecânica ou elétrica; se elétrica ela necessita de um motor, então o software questiona qual a potência e tensão que deve ter o motor; outro questionamento é se a bomba tem sistema próprio de controle, se não, então ela exige instrumentação e o software questiona o que será utilizado para automatizá-la.

No COMOS tudo o que é alterado por um usuário fica visível a todos, então as informações fluem mais facilmente. Outros softwares também foram utilizados, como InTools, PTW Dapper e PDMS.

\subsubsection{A criação de capacitações dinâmicas pela CNC}

A criação de capacitações dinâmicas pela CNC poderá ser vista sob dois aspectos. O primeiro aspecto diz respeito aos mecanismos de aprendizagem de Zollo e Winter (2002), conforme será sintetizado no quadro 10.

Além da reestruturação da empresa, que pode ser verificada através de informações como a abertura de um novo escritório no Rio de Janeiro, da reestruturação do departamento de $\mathrm{TI}$, com a compra de novas máquinas, novas licenças e softwares e a contratação de pessoal especializado, há que se considerar o avanço da empresa nas práticas adotadas para atender às exigências da Petrobras. Tais exigências, como podem ser percebidas, vão além de exigências contratuais ou précontratuais. Trata-se de um novo conceito de trabalho, mais voltado à especialização de tarefas, à alta qualidade dos serviços prestados e, principalmente, ao acúmulo de competências internas. 


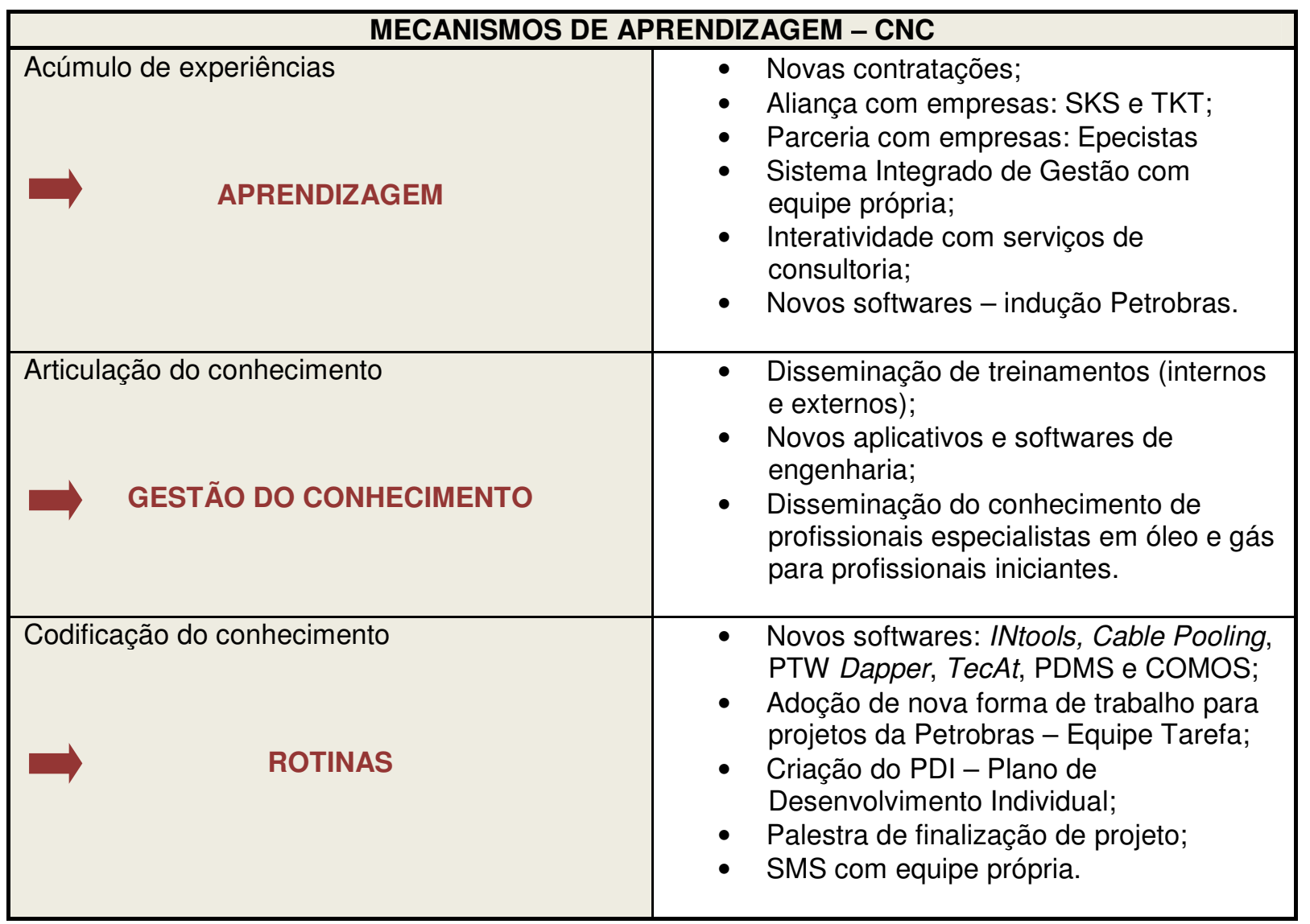

Quadro 10 - Mecanismos de aprendizagem CNC

Fonte: Autora

segundo aspecto diz respeito aos indicadores destacados em cada projeto, a fim de evidenciar a evolução das capacitações da empresa. Serão considerados os seguintes indicadores: número de engenheiros envolvidos; número de softwares utilizados (aprendidos); número de rotinas ou procedimentos criados e alianças com outras empresas, conforme será sintetizado no quadro 11. 


\begin{tabular}{|c|c|c|c|}
\hline $\mathrm{C} \mathrm{NC}$ & $\begin{array}{l}\text { PROJETO } 1 \\
\text { Outubro/2007 }\end{array}$ & $\begin{array}{l}\text { PROJETO } 2 \\
\text { Junho/2008 }\end{array}$ & $\begin{array}{c}\text { PROJETO } 3 \\
\text { Fevereiro/2009 }\end{array}$ \\
\hline $\begin{array}{l}\text { NÚMERO DE } \\
\text { ENGENHEIROS }\end{array}$ & 35 & 75 & 180 \\
\hline $\begin{array}{l}\text { CAPACITAÇÃO EM } \\
\text { SOFTWARES }\end{array}$ & $\begin{array}{l}\text { - INtools; } \\
\text { - PDS; }\end{array}$ & $\begin{array}{l}\text { - Cable Pooling; } \\
\text { - PTW Dapper; } \\
\text { - TecAt; } \\
\text { - PDMS. }\end{array}$ & - cOMOS. \\
\hline ROTINAS CRIADAS & $\begin{array}{l}\text { - } \text { Agregada a } \\
\text { utilização do } \\
\text { software INtools; } \\
\text { - Início do } \\
\text { procedimento para } \\
\text { utilização do } \\
\text { software PDS. }\end{array}$ & $\begin{array}{l}\text { - Consolidação da } \\
\text { prática de equipe } \\
\text { tarefa para projetos } \\
\text { Petrobras; } \\
\text { - Agregada a } \\
\text { utilização dos } \\
\text { softwares Cable } \\
\text { Pooling, PTW } \\
\text { Dapper, TecAt e } \\
\text { PDMS. }\end{array}$ & $\begin{array}{l}\text { - Agregada a } \\
\text { utilização do } \\
\text { software COMOS; } \\
\text { - SMS com equipe } \\
\text { própria. }\end{array}$ \\
\hline $\begin{array}{c}\text { ALIANÇAS COM } \\
\text { OUTRAS EMPRESAS }\end{array}$ & $\begin{array}{l}\text { - EPC; } \\
\text { - Basf. }\end{array}$ & $\begin{array}{l}\text { - EPC; } \\
\text { - Vale. }\end{array}$ & • EPC. \\
\hline
\end{tabular}

Quadro 11 - Indicadores de capacitação dinâmica - CNC

Fonte: Autora

O quadro 11 mostra que houve aumento no número de engenheiros alocados em cada projeto. Esta constatação pode significar o aumento das dificuldades técnicas e dos riscos que envolvem os projetos. Outra constatação é que, cada vez mais, a CNC estará preparada para abarcar projetos que, até então, não possuía competência para gerir. Outro fato que merece destaque é o conhecimento que os profissionais contratados trazem para dentro da empresa, o que aumenta sua massa especialista com a disseminação e a troca de experiências entre os profissionais.

Quanto à capacitação em softwares, o quadro mostra que a cada projeto a empresa viu-se obrigada a buscar uma nova ferramenta de trabalho, até então desconhecida. Se compararmos os 3 projetos, concluiremos que no decorrer deles a CNC tornouse apta a desenvolver projetos utilizando-se de 7 novas ferramentas. Embora 0 processo tenha sido induzido pela Petrobras, o ganho de experiência e de 
aprendizagem permanecerá na empresa, o que corrobora com a afirmação de que há grande possibilidade de aumentar sua competitividade perante as demais empresas do setor.

Quanto às rotinas criadas, estas são consideradas as 'saídas' das capacitações dinâmicas, ou seja, o produto após a transformação dos recursos (conhecimento) da empresa. Tais rotinas, conforme informação coletada em entrevista, servem para organizar o trabalho e podem ser reconfiguradas à medida em que as necessidades aparecem.

Outra fonte de aprendizagem e de capacitação é mostrada através das alianças e/ou parcerias geradas por consequência do acúmulo do conhecimento e das capacitações no decorrer dos projetos. Ser fornecedor da Petrobras significa, perante o mercado, ser capacitado a desenvolver projetos com a qualidade e a confiabilidade exigida pelas empresas de porte, o que remete as empresas de serviços de engenharia que atendem a Petrobras à um patamar diferenciado no setor.

Embora o projeto 3 não tenha rendido alianças, vale ressaltar que, em função do aprendizado alcançado no projeto, a empresa CNC optou por investir no aumento da sua carteira de clientes do segmento elétrico e está investindo na criação de um novo departamento que será especializado em grandes obras do setor elétrico.

A tabela 4 trará um resumo do que foi pesquisado em ocasião das entrevistas de campo da fase 2. 
Tabela 4 - Dados dos projetos analisados na CNC

\begin{tabular}{|c|c|c|c|c|c|c|c|c|c|c|c|}
\hline & Título & $\begin{array}{c}\text { Início } \\
\text { (Mês/Ano) }\end{array}$ & $\begin{array}{c}\text { No Pessoal } \\
\text { Especializado }\end{array}$ & $\begin{array}{l}\text { Contratação de } \\
\text { Conhecimento } \\
\text { Especializado }\end{array}$ & $\begin{array}{l}\text { Contratação de } \\
\text { Serviços de } \\
\text { Consultoria }\end{array}$ & $\begin{array}{l}\text { Softwares } \\
\text { Utilizados }\end{array}$ & $\begin{array}{l}\text { Principais } \\
\text { Rotinas }\end{array}$ & $\begin{array}{l}\text { Maior } \\
\text { Desafio }\end{array}$ & $\begin{array}{c}\text { Maior } \\
\text { Aprendizado }\end{array}$ & $\begin{array}{l}\text { Projeto } \\
\text { Gerou } \\
\text { Alianças? }\end{array}$ & $\begin{array}{c}\text { Projeto } \\
\text { Proporcionou } \\
\text { Novos } \\
\text { Clientes? }\end{array}$ \\
\hline Projeto 1 & $\begin{array}{l}\text { Execução de } \\
\text { Usina } \\
\text { Termelétrica a } \\
\text { Gás }\end{array}$ & $\begin{array}{c}\text { Outubro } \\
2007\end{array}$ & $\begin{array}{c}35 \\
\text { Engenheiros }\end{array}$ & SMS & $\begin{array}{l}\text { - Levantamento de } \\
\text { balanço térmico; } \\
\text { - Análise de risco e } \\
\text { de distância segura; } \\
\text { - Estudo específico } \\
\text { de demanda de } \\
\text { energia; } \\
\text { - Estudo de redes } \\
\text { interligadas. }\end{array}$ & $\begin{array}{l}\text { - INtools } \\
\text { - PDS }\end{array}$ & $\begin{array}{l}\text { Agregada a } \\
\text { utilização PDS }\end{array}$ & $\begin{array}{l}\text { Adaptar-se aos } \\
\text { equipamentos } \\
\text { já comprados } \\
\text { e ao pouco } \\
\text { espaço físico }\end{array}$ & $\begin{array}{l}\text { Estudo de } \\
\text { estabilidade de } \\
\text { vapor e de } \\
\text { estabilidade } \\
\text { elétrica }\end{array}$ & SKS & Basf \\
\hline Projeto 2 & $\begin{array}{c}\text { Planta para } \\
\text { Carteira de } \\
\text { Gasolina }\end{array}$ & $\begin{array}{l}\text { Junho } \\
2008\end{array}$ & $\begin{array}{c}75 \\
\text { Engenheiros }\end{array}$ & SMS & $\begin{array}{l}\text { - Estudo do projeto } \\
\text { civil; } \\
\text { - Análise das } \\
\text { regulamentações e } \\
\text { requisitos do } \\
\text { projeto; }\end{array}$ & $\begin{array}{l}\text { - In Tools } \\
\text { - Cable } \\
\text { Pooling } \\
\text { - PTW Dapper } \\
\text { - TecAt } \\
\text { - PDMS }\end{array}$ & $\begin{array}{l}\text { - Consolidação } \\
\text { da Equipe } \\
\text { Tarefa; } \\
\text { - Utilização } \\
\text { Cable Pooling, } \\
\text { PTW Dapper, } \\
\text { TecAt e PDMS }\end{array}$ & $\begin{array}{l}\text { Cabeamento } \\
\text { subterrâneo }\end{array}$ & $\begin{array}{l}\text { Envelopamento } \\
\text { de subsolo }\end{array}$ & TKT & Vale \\
\hline Projeto 3 & $\begin{array}{l}\text { FEED para } \\
\text { Complexo } \\
\text { Petroquímico }\end{array}$ & $\begin{array}{l}\text { Fevereiro } \\
2009\end{array}$ & $\begin{array}{c}180 \\
\text { Engenheiros }\end{array}$ & $\begin{array}{c}-*_{-} \\
\text {SMS com } \\
\text { Equipe Própria }\end{array}$ & $\begin{array}{l}\text { Simulação do } \\
\text { Sistema Elétrico }\end{array}$ & $\begin{array}{l}\text { - In Tools } \\
\text { - PTW Dapper } \\
\text { - PDMS } \\
\text { - COMOS }\end{array}$ & $\begin{array}{l}\text { Agregada a } \\
\text { utilização do } \\
\text { COMOS }\end{array}$ & $\begin{array}{l}\text { Instalação } \\
\text { elétrica aérea } \\
\text { (mudança de } \\
\text { concepção das } \\
\text { refinarias) }\end{array}$ & $\begin{array}{l}\text { Avanço na } \\
\text { modelagem 3D }\end{array}$ & WP & $\begin{array}{l}\text { Estão } \\
\text { investimento no } \\
\text { aumento da } \\
\text { carteira de } \\
\text { clientes do } \\
\text { segmento } \\
\text { elétrico }\end{array}$ \\
\hline
\end{tabular}

Fonte: Pesquisa de campo. Elaborada pela autora. 


\subsection{APRESENTAÇÃO DA EMPRESA GPR}

Com capital 100\% nacional, a empresa GPR ocupa posição de destaque entre as maiores companhias de engenharia de projetos no Brasil. Com escritórios em São Paulo, Rio de Janeiro e Salvador, a empresa atua nos mais diversos segmentos de mercado: Petróleo \& Gás, Petroquímica, Química, Celulose e Papel, Mineração, Siderurgia, Alimentos, Indústria de Manufatura, Farmacêutica e de Cosméticos, etc.

A empresa oferece serviços de engenharia para empreendimentos industriais, desde a fase inicial de concepção e orçamentação, até a partida e operação inicial da instalação. Todos os seus serviços são executados por engenheiros e técnicos especializados, dando a ela a condição de fornecer projetos básicos e de detalhamento para áreas de processo, mecânica, tubulação, automação, dentre outras especialidades.

Contando atualmente com 730 colaboradores diretos, a empresa GPR declara-se não optante por contratação de mão-de-obra terceirizada; em primeiro lugar devido a sua preocupação e zelo com a qualidade dos serviços prestados; e em segundo lugar, essa opção deve-se ao fato do consenso entre os diretores de que a necessidade de subcontratação retrata a necessidade de aumento no quadro funcional, sendo, então, uma oportunidade para gerar novos empregos para o setor.

As entrevistas para a segunda fase da pesquisa na GPR contaram com a participação de 6 respondentes: 


\begin{tabular}{|c|c|c|c|}
\hline EMPRESA & $\begin{array}{c}\text { DATA DA } \\
\text { EMTREVISTA }\end{array}$ & PARTICIPANTE & $\begin{array}{l}\text { DURAÇĀO } \\
\text { (HORAS) }\end{array}$ \\
\hline & $19 / 05 / 2011$ & Gerente de Engenharia & $1: 12$ \\
\hline GPR & 01/06/2011 & $\begin{array}{l}\text { Gerente de Desenvolvimento de Negócios } \\
\text { Gerente de Engenharia } \\
\text { Gerente de Sistemas Corporativos } \\
\text { Gerente de Engenharia Elétrica } \\
\text { Gerente de Tubulação } \\
\text { Gerente de Instrumentação }\end{array}$ & $6: 00$ \\
\hline & & TEMPO TOTAL & $7: 12$ \\
\hline
\end{tabular}

Quadro 12 - Respondentes da segunda fase da pesquisa na GPR.

Fonte: Autora

\subsubsection{Relação GPR / PETROBRAS}

Sendo a Petrobras uma empresa optante pelo gerenciamento de vários projetos na modalidade EPC (Engineering, Procurement \& Construction), e empresa GPR obteve seu primeiro contrato/negócio com a Petrobras no ano 2000.

A Petrobras é um "cartão de visitas" para outros contratos, segundo informações do Gerente de Engenharia. Hoje, empresas estrangeiras procuram a GPR devido à experiência que tem com a Petrobras, e isso também tem rendido parcerias e negócios com outras empresas do setor de óleo e gás, além do transbordamento para os setores petroquímicos, sucroalcooleiro, químico, entre outros.

Atualmente, $65 \%$ da receita da empresa $G$ provêm de contratos com a Petrobras. "Esta relação de parceria exige das empresas prestadoras de serviço de engenharia a busca constante pela excelência, focando o aprendizado a cada novo projeto" (Gerente de Desenvolvimento de Negócios). Desta forma, objetivando o crescente aumento de suas capacitações, a empresa espera aumentar seus vínculos com a Petrobras. 
Diante deste fato, a empresa GPR segue, até hoje, buscando melhorar seus processos e criar novas capacitações.

A busca pela atualização em TI (Tecnologia da Informação), por exemplo, rendeu à empresa um prêmio internacional pelo uso e aplicação de softwares de engenharia com modelagem tridimensional, no caso o software COMOS, que integra os projetos elétrico/tubulação/instrumentação numa mesma base.

Os próximos tópicos serão dedicados a descrever como se dá a preparação da GPR para atender a Petrobras, considerando seu papel indutivo na criação das capacitações dos seus fornecedores.

\subsubsection{GPR e a mudança na estrutura da empresa}

A empresa GPR admite ter crescido muito a partir do ganho de projetos com a Petrobras. Houve um aumento na capacitação técnica da empresa, na atualização de pessoal quanto às especializações de engenharia e à busca pelos melhores e mais atuais softwares, ganhando assim maior visibilidade internacional.

A participação da empresa no projeto 1 foi o marco para o início de uma grande reestruturação na empresa. Conforme citado pelo Gerente de Engenharia, "quando vimos a oportunidade de crescer com os projetos da Petrobras, adotamos uma cultura de desenvolvimento de competências internas e enxergamos nisso um ganho de qualidade e de tempo dos profissionais".

A empresa diz ter investido fortemente em recursos humanos, softwares e hardwares. A cada três anos a companhia troca todo o parque de computadores, de forma que suas máquinas suportem os softwares de ponta exigidos pela Petrobras. Além disso, a GPR trouxe para dentro do Departamento de $\mathrm{TI}$ um Centro de Pesquisa e Desenvolvimento para confecção de novos softwares e ferramentas de engenharia. 
Segundo o Gerente de Sistemas Corporativos, foi criada uma ferramenta para triagem das ideias, que é compartilhada com atores externos (clientes, fornecedores, parceiros, etc.). As ideias, segundo informado, são colocadas no sistema, que as avalia, cruza e fornece uma resposta entre "avaliar" ou "não dar seguimento". Esta implantação nasceu a partir da relação com a Petrobras: "todas as ideias devem ser ouvidas e formatadas... ninguém ganha sozinho, então passamos a compartilhar e buscar ideias com nossos clientes quanto às ferramentas que utilizamos" (Gerente de Sistemas Corporativos).

Em decorrência da estruturação de $\mathrm{TI}$ e do número de contratados para todas as disciplinas de engenharia, além dos cargos administrativos, a estrutura física da empresa também foi alterada passando da ocupação de 3 para 8 andares de um prédio comercial.

Há um trabalho forte da engenharia para a customização e a configuração dos softwares, por isso, a empresa diz ter quadruplicado seu efetivo nos últimos 7 anos, principalmente para a área de TI, conforme cita o Gerente Sistemas Corporativos:

"Todo esse trabalho depende de uma estrutura grande e especialista por trás... a confecção do banco de dados, as configurações, os desenvolvimentos e customizações de softwares exigem especialistas de diversas áreas da engenharia... a equipe de sistemas tem que estudar manuais, software e preparar cada ferramenta. Há também muita pesquisa e desenvolvimento junto aos parceiros".

Tal estrutura ganhou notoriedade no mercado e a empresa ganhou vários projetos com clientes dos mais diversos segmentos (papel e celulose, vidro, cerâmica, alimentos, etc.). A estrutura montada para atender a Petrobras era a mesma que atendia aos demais clientes, e estes, perceberam o aumento da qualidade dos projetos oferecidos. "a quantidade de erros nos projetos diminuiu muito com a utilização dos softwares que permitiam a modelagem em 3D... e isso é primordial para uma empresa de serviço de engenharia" (Gerente de Engenharia). 


\subsubsection{GPR e a competência técnica}

Após a adoção de uma cultura voltada ao desenvolvimento de competências, a GPR passou a oferecer treinamento para engenheiros especialistas, além dos projetistas e desenhistas. A contrapartida para aos profissionais que eram treinados fora era disseminar o conhecimento internamente, através de cursos para outros funcionários. Esta prática, segundo o Gerente de Sistemas Corporativos, quebrou muitos paradigmas internos, visto que grande parte dos profissionais tem mais de 30 anos de experiência.

A troca de experiências foi ponto de maior satisfação perante os gerentes: "Nós cultivamos a prática do 'ganha-ganha', onde o profissional com maior experiência técnica, divide seu conhecimento com os profissionais iniciantes (os juniores da era dos games) e esses, por sua vez, dividem o conhecimento através da habilidade com as ferramentas de TI" (Gerente de Desenvolvimento de Negócios).

Segundo informado pelo Gerente de Desenvolvimento de Negócios, o ganho de competência técnica tem sido sentido não só pela Petrobras, mas por todos os clientes que compõem a carteira da empresa.

"Nós investimos muito em pessoas, elas são imprescindíveis para o nosso "produto" e os projetos da Petrobras nos induz a alta capacitação" (Gerente de Engenharia).

\subsubsection{GPR e as subcontratações}

Para atender ao escopo dos projetos da Petrobras, cabe à empresa de serviços de engenharia buscar caminhos para a realização de atividades que estejam fora da sua capacitação. Desta forma, sempre que necessário, a GPR serviços de consultoria para a realização de estudos e análises específicas, cuja competência ainda não tenha sido desenvolvida internamente. 
Quanto à contratação de mão-de-obra terceirizada, a empresa se diz não optante.

Na sequência serão descritos os três projetos analisados na CNC, bem como suas particularidades:

\subsubsection{Projeto 1 - Planta de tratamento de gás da refinaria}

O projeto 1 da GPR teve início em outubro/2004. Para execução deste projeto, a GPR contou com a participação de 18 engenheiros diretos.

O objetivo do projeto foi a criação de uma unidade de tratamento de gás para uma das refinarias da Petrobras.

A participação da GPR no projeto 1 deu início a uma grande reestruturação na empresa. A grande revolução foi na área de sistemas. Neste projeto a Petrobras exigiu que a planta de tubulação fosse apresentada em 3D (PDMS) e a GPR foi buscar no mercado um profissional com esta competência. Tendo sido contratado para a elaboração da planta, coube ao novo empregado treinar os 6 engenheiros da casa, especialistas da disciplina de tubulação. As outras disciplinas de engenharia continuavam a entregar suas plantas através de softwares aplicativos de engenharia.

A partir deste projeto, foi criado um procedimento para a disciplina de tubulação, que passaria a modelar somente em 3D, independente da necessidade do projeto. Tal procedimento era revisitado à medida que os engenheiros encontravam entraves ou tinham sugestões para customização da ferramenta (que no caso do PDMS pode ser remodelada conforme a necessidade de cada empresa).

Quando a GPR percebeu o ganho de qualidade da modelagem em 3D na disciplina de tubulação, optaram por expandir a ferramenta para outras disciplinas de engenharia (elétrica e instrumentação), o que traria alto ganho na qualidade dos projetos da empresa. 
Foi então que a empresa contratou no mercado um treinamento de modelagem para os 18 engenheiros da casa, de todas as disciplinas (tubulação, elétrica e instrumentação). A intenção da empresa era capacitar os engenheiros para trabalhar na plataforma 3D a partir dos próximos projetos.

Para desenvolver o projeto 1, a empresa GPR contou com serviços de consultoria de profissionais e empresas detentoras de vasta experiência:

- Consultoria para estudo geotécnico;

- Consultoria para análise de sistemas elétricos;

- Consultoria para análise de flexibilidade;

- Consultoria para a tríplice classificação empresarial em sistema de gestão da qualidade (ISO 9.001); de meio ambiente (ISO 14.001); e de saúde e segurança no trabalho (OHSAS 18.001).

O maior desafio do projeto, conforme informação do Gerente de Engenharia foi, sem dúvida, treinar os engenheiros da disciplina de tubulação.

Quanto aos softwares utilizados, além dos aplicativos de engenharia, houve a necessidade de trabalhar com o software específico para a modelagem 3D, que estava além das competências da empresa até aquele momento.

- PDMS (Plant Design Management System) - software utilizado para a confecção de projetos com modelagem 3D, unindo as áreas de elétrica, tubulação e instrumentação. Na medida em que são lançadas as informações, o software vai construindo toda a planta e é possível navegar por ela. Para cada característica alterada no projeto, o software realiza e aponta as alterações em toda a planta do projeto, integrando todas as áreas e dando 
uma visão tridimensional do projeto como um todo. Com ele, tem-se uma fotografia do projeto pronto, do que será construído.

A empresa GPR foi contratada para este projeto através de uma empresa epecista. Devido à qualidade do projeto apresentado, a empresa diz ter sido contratada diversas outras vezes para desenvolver, com a mesma epecista, os projetos em 3D (tubulação), ou seja, a capacitação nessa nova modelagem abriu portas no mercado.

\subsubsection{Projeto 2 - FEED para carteira de propeno}

O projeto 2 da GPR teve início em agosto/2006. Para execução deste projeto, a CNC contou com a participação de 103 engenheiros diretos.

O projeto FEED (Front and Engineering Design) é uma modalidade de projeto adotada pela Petrobras, cujo objetivo é analisar a consistência do projeto básico e estimar o valor do total da obra. Consiste também do pré-detalhamento do projeto executivo. Cabe ao FEED efetuar um levantamento prévio da média de custos dos projetos.

No projeto 2, a revolução continuou na área de sistemas e abarcou também as

disciplinas de engenharia elétrica e instrumentação. Além disso, houve a consolidação da equipe de análise de flexibilidade, que anteriormente era feita através da contratação de consultoria externa.

A empresa criou, então, um novo procedimento que agora (atuando via software) integrava as três disciplinas de engenharia (tubulação, elétrica e instrumentação) na mesma plataforma. O objetivo, além do ganho em qualidade $3 \mathrm{D}$, era criar uma nova cronologia de atuação das disciplinas.

Antes da utilização do software PDMS, as plantas de cada disciplina eram feitas separadamente, atendendo a alguns entraves de tempo, o que consistia em uma 
disciplina modelar até determinado nível para que outra pudesse iniciar seu trabalho de detalhamento. Hoje, com o PDMS, as disciplinas podem trabalhar em paralelo na mesma plataforma, não sendo necessário aguardar a ordem cronológica de entrada das disciplinas.

Em ocasião deste projeto, a GPR adquiriu a licença para utilização de um novo software - COMOS. Trata-se da primeira empresa brasileira a adquirir sua licença.

A utilização deste software foi sinalizada pelo Centro de Pesquisa e Desenvolvimento do Departamento de TI (talvez a primeira grande contribuição do centro de pesquisa). Como oportunidade de aprendizado, a empresa utilizou a plataforma do software COMOS para a elaboração apenas da planta elétrica do projeto. Depois de desenvolver o banco de dados e iniciar a utilização do COMOS (customização), os profissionais da área de $\mathrm{TI}$ perceberam algumas falhas no software e chegaram a contatar o fornecedor e redesenharam algumas telas para atender à customização necessária.

Feito isto o projeto pôde ser apresentado à Petrobras, contemplando a nova ferramenta de trabalho. Diante da qualidade do projeto, a GPR foi surpreendida pelo convite da Petrobras para desenvolver junto á ela a customização da plataforma COMOS, conforme as necessidades da Petrobras. A partir deste convite, as três empresas (GPR / Petrobras / empresa desenvolvedora do software) se integraram para criar uma plataforma customizada e especialmente desenhada para os projetos da Petrobras. Segundo informações do Gerente de Sistemas Corporativos, a GPR precisou trabalhar arduamente com o desenvolvedor do software COMOS, sinalizando onde ele deveria melhorar a ferramenta, onde havia entraves, etc.

Esta parceria rendeu à GPR alta credibilidade e confiança por parte da Petrobras: “...tudo o que a Petrobras nos solicitou foi feito" (Gerente de Sistemas Corporativos).

Sendo aprovada a utilização do software COMOS pela Petrobras, e esta já tendo sinalizado que sua utilização não estava longe de ser obrigatória para todas as disciplinas de engenharia, a GPR passou a desenvolver novos procedimentos para sua utilização. 
"Com a modelagem 3D, à medida que uma disciplina avança na modelagem, as outras já podem iniciar seus estudos de detalhamento" (Gerente de Sistemas Corporativos). Este novo procedimento previa alguns cuidados que cada disciplina deveria considerar. Um deles era o melhor momento de iniciar a modelagem, outro era a trava de inclusão de "entidades" no projeto. Entende-se por entidade cada item a ser inserido no projeto, por exemplo, um novo equipamento, um novo dimensionamento, etc., que eram previamente analisados pelo pessoal de sistemas junto ao gerente do projeto (inserção no banco de dados desenvolvido internamente).

Outro procedimento adotado pela GPR foi o ERA3D - software de controle do COMOS. Este software permite a empresa controlar a geração de relatórios, entidades a serem incluídas no banco de dados, documentação de evolução da maquete (seja por linha modelada, seja por criação de objetos), entre outras facilidades. Todas as aplicações deste software se revertem em dados tanto para a GPR quanto para a Petrobras, através da geração índices. Conforme citou o Gerente de Engenharia, é possível saber, por exemplo, a porcentagem de trabalho executado por projeto:

"antes, toda medição era feita por um funcionário da Petrobras, que visitava a empresa e perdia um dia lendo relatórios e verificando desenhos... hoje, sempre que um profissional faz qualquer alteração na plataforma, configurando um trabalho executado, $o$ software nos fornece, em tempo real, a porcentagem do projeto que já está feita e a que temos a fazer... isso considerando que o software também cruza estas informações com o cronograma de execução do projeto, o que nos sinaliza se há ou não atraso".

Esta ferramenta permite ao gerente do projeto medir quanto cada disciplina evoluiu no projeto (diariamente, semanalmente, etc.).

Outra ação da empresa em decorrência do projeto 2 foi a criação da disciplina de Engenharia de Telecomunicações. A experiência da GPR mostrava que havia uma lacuna de conhecimento entre as disciplinas de elétrica e instrumentação. A partir 
daí, a nova disciplina passou a tramitar entre as outras duas: elétrica e instrumentação.

Para desenvolver o projeto 2, a empresa GPR contou com serviços de consultoria de profissionais e empresas detentoras de vasta experiência:

- Consultoria para estudo geotécnico;

- Consultoria para a tríplice classificação empresarial em sistema de gestão da qualidade (ISO 9.001); de meio ambiente (ISO 14.001); e de saúde e segurança no trabalho (OHSAS 18.001).

As análises de sistemas elétricos e de flexibilidade, que antes eram contratadas externamente, foram desenvolvidas pela equipe formada e treinada pela GPR, visto que são análises corriqueiras nos projetos da Petrobras: "achamos melhor criar uma equipe que pudesse desenvolver tais competências, e acreditamos que houve ganho com isso" (Gerente de Engenharia Elétrica).

Quanto aos softwares utilizados, além dos aplicativos de engenharia, houve a necessidade de trabalhar com os softwares:

- PDMS, considerando a integração das disciplinas de elétrica e instrumentação;

- COMOS, apenas para modelagem da equipe de elétrica;

- $\quad$ TRIPLEX, utilizado pela equipe de análise de flexibilidade.

A partir da utilização do software COMOS para a disciplina de elétrica neste projeto, a GPR passou a integrar as disciplinas de tubulação e instrumentação nos projetos posteriores. 


\subsubsection{Projeto 3 - Planta para carteira de gasolina}

O projeto 3 foi desenvolvido em julho/2010. Para a execução deste projeto, a GPR contou com a participação de, aproximadamente, 194 engenheiros diretos.

Este foi o projeto da Petrobras de maior dificuldade técnica para a GPR. Outra empresa havia apresentado o projeto FEED, porém a Petrobras cancelou o contrato em função de várias incorreções no projeto, além da qualidade ruim. Porém, o cancelamento do FEED pela Petrobras foi feito quando já estavam em fase de execução da obra, ou seja, já havia uma empresa epecista trabalhando em campo.

Devido à confiabilidade demonstrada pela GPR ao longo da relação, a Petrobras fez o convite para que a GPR assumisse o projeto FEED. A partir disso a GPR iniciou uma corrida contra o tempo, pois a obra já havia iniciado. Depois de analisar os projetos Básico e FEED, a GPR detectou várias falhas e optou por elaborar um novo projeto.

Dando início a elaboração do projeto, a GPR contratou profissionais especialistas para abarcar competências que não dispunha internamente, selecionou pessoal interno tanto das disciplinas de engenharia quanto das funções administrativas e montou uma grande equipe que foi alocada na obra (campo). Parte da estrutura de TI também se deslocou, visando facilitar a utilização e/ou remodelagem das ferramentas de sistemas. Vale ressaltar que esta prática de alocação de pessoal não foi adotada como procedimento, ocorrendo apenas neste projeto.

Vários foram os entraves encontrados pela equipe: realização do cálculo para puxamento e ampacidade dos cabos; adaptação da equipe para trabalhar em condições adversas; desenvolver o projeto com maior precisão e em menos tempo do que o habitual; proceder com análise de campo detalhadas, etc.

Tendo sido atendidas todas as exigências da Petrobras, a empresa GPR, mais uma vez, fortaleceu sua imagem como fornecedora de serviços de engenharia. 
Para desenvolver o projeto 3, a empresa GPR contou com serviços de consultoria para a elaboração do estudo geotécnico.

A tríplice classificação empresarial em sistema de gestão da qualidade (ISO 9.001); de meio ambiente (ISO 14.001); e de saúde e segurança no trabalho (OHSAS 18.001) foi feita por equipe desenvolvida internamente.

Quanto aos softwares utilizados, além dos aplicativos de engenharia e softwares já conhecidos (TRIPLEX, PDMS, INtools, PTW Dapper, etc.), houve a opção por trabalhar com o software COMOS, já considerando a modelagem 3D para as três disciplinas: tubulação, elétrica e instrumentação.

Tendo sido consagrada a utilização do software COMOS para os futuros projetos, a GPR criou um procedimento que chamaram Review-3D, que consistia em analisar e informar ao gerente do projeto toda e qualquer alteração na plataforma do COMOS. "Sempre que um engenheiro faz uma anotação, inclui uma entidade, envia um parecer....todas as pessoas alocadas no projeto são informadas, cabendo a cada um tomar as providências necessárias, se solicitadas, para o andamento do projeto" (Gerente de Sistemas Corporativos).

Outra ação da empresa foi criar o cargo de Coordenador de Modelagem 3D. Cabe a este coordenador cuidar de todos os assuntos referentes a plataforma 3D: atualização e/ou aquisição de softwares, necessidade de treinamento, etc.

\subsubsection{A criação de capacitações dinâmicas pela GPR}

A criação de capacitações dinâmicas pela GPR poderá ser vista sob dois aspectos. O primeiro aspecto diz respeito aos mecanismos de aprendizagem de Zollo e Winter (2002), conforme será sintetizado no quadro 13.

Além da reestruturação da empresa, que pode ser verificada através de informações como a expansão da empresa de 3 para 8 andares de um prédio comercial, a 
reestruturação do departamento de $\mathrm{TI}$, com a compra de novas máquinas (a cada 3 anos), a compra de novas licenças e softwares e a contratação de pessoal especializado, a criação de um centro de P\&D exclusivo, há que se considerar o avanço da empresa nas práticas adotadas para atender às exigências da Petrobras. Em grande parte, a empresa procurou antecipar-se as exigências.

\begin{tabular}{|c|c|}
\hline \multicolumn{2}{|c|}{ MECANISMOS DE APRENDIZAGEM - GPR } \\
\hline Acúmulo de experiências & 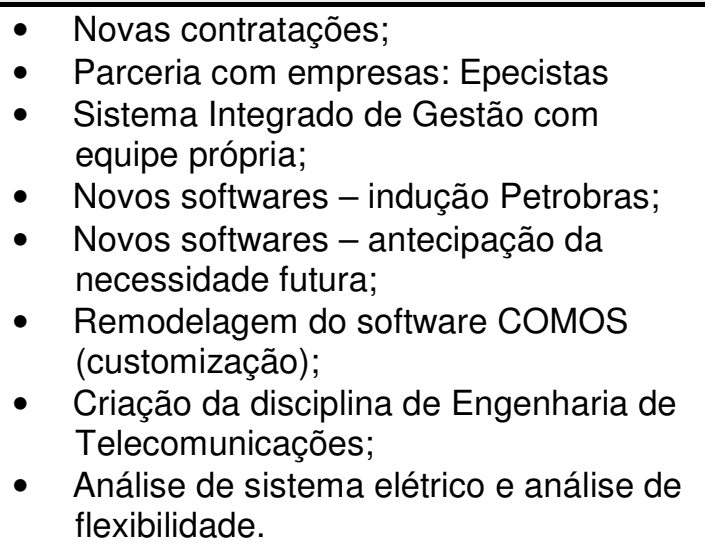 \\
\hline$\Rightarrow$ GESTÃO DO CONHECIMENTO & $\begin{array}{l}\text { - Disseminação de treinamentos (internos } \\
\text { e externos); } \\
\text { - } \\
\text { engos aplicativos e softwares de } \\
\text { - } \quad \text { Disseminaçãão do conhecimento entre } \\
\text { profissionais experientes (tecnicamente) } \\
\text { e profissionais iniciantes (habilidade em } \\
\text { softwares); } \\
\text { - Criação de um centro de P\&D dedicado } \\
\text { à área de TI; } \\
\text { - Ferramenta para triagem de ideias. }\end{array}$ \\
\hline Codificação do conhecimento & $\begin{array}{l}\text { - } \quad \text { Novos softwares: INtools, Cable Pooling, } \\
\text { PTW Dapper, TecAt, PDMS e COMOS; } \\
\text { - Criação do cargo de Coordenador de } \\
\text { - } \quad \text { Sodelagem 3D; } \\
\text { - } \quad \text { Procedimento para a disciplina de } \\
\quad \text { tubulação modelar em 3D; } \\
\text { - } \quad \text { Procedimento para a disciplina de } \\
\text { elétrica modelar em 3D; } \\
\text { - Procedimento para a disciplina de } \\
\text { instrumentação modelar em 3D; } \\
\text { - Software ERA3D para controle de } \\
\text { - } \quad \text { Clterações no COMOS; } \\
\quad \text { Telecomuno dicações; } \\
\text { - Procedimento Review para 3D. }\end{array}$ \\
\hline
\end{tabular}

Quadro 13 - Mecanismos de aprendizagem GPR

Fonte: Autora 
segundo aspecto diz respeito aos indicadores destacados em cada projeto, a fim de evidenciar a evolução das capacitações da empresa. Serão considerados os seguintes indicadores: número de engenheiros envolvidos; número de softwares utilizados (aprendidos); número de rotinas ou procedimentos criados e alianças com outras empresas, conforme será sintetizado no quadro 14.

\begin{tabular}{|c|c|c|c|}
\hline GPR & $\begin{array}{l}\text { PROJETO } 1 \\
\text { Outubro/2004 }\end{array}$ & $\begin{array}{l}\text { PROJETO } 2 \\
\text { Agosto/2006 }\end{array}$ & $\begin{array}{l}\text { PROJETO } 3 \\
\text { Julho/2010 }\end{array}$ \\
\hline $\begin{array}{l}\text { NÚMERO DE } \\
\text { ENGENHEIROS }\end{array}$ & 18 & 103 & 194 \\
\hline $\begin{array}{l}\text { CAPACITAÇÃO EM } \\
\text { SOFTWARES }\end{array}$ & - PDMS (tubulação) & $\begin{array}{l}\text { - PDMS } \\
\text { (instrumentação) } \\
\text { - COMOS (elétrica) } \\
\text { - TRIPLEX (equipe de } \\
\text { flexibilidade) }\end{array}$ & $\begin{array}{l}\text { - COMOS } \\
\text { (tubulação, elétrica } \\
\text { e instrumentação) } \\
\text { - ERA3D } \\
\text { - Review-3D }\end{array}$ \\
\hline ROTINAS CRIADAS & $\begin{array}{l}\text { - Procedimento para } \\
\text { modelagem da } \\
\text { tubulação em 3D; }\end{array}$ & $\begin{array}{l}\text { - Procedimento para } \\
\text { modelagem da } \\
\text { elétrica e } \\
\text { instrumentação em } \\
\text { 3D; } \\
\text { - Procedimento para } \\
\text { inclusão de objeto } \\
\text { ou entidade na } \\
\text { plataforma 3D. }\end{array}$ & $\begin{array}{l}\text { - Procedimento para } \\
\text { utilização do } \\
\text { software Review- } \\
\text { 3D; } \\
\text { - Criação do cargo } \\
\text { de Coordenador de } \\
\text { Modelagem 3D; } \\
\text { - SMS com equipe } \\
\text { própria. }\end{array}$ \\
\hline $\begin{array}{c}\text { ALIANCSAS COM } \\
\text { OUTRAS EMPRESAS }\end{array}$ & - EPC; & - EPC; & $-{ }^{*}-$ \\
\hline
\end{tabular}

Quadro 14 - Indicadores de capacitação dinâmica - GPR

Fonte: Autora

O quadro 14 mostra que houve aumento no número de engenheiros alocados em cada projeto. Esta constatação pode significar o aumento das dificuldades técnicas e dos riscos que envolvem os projetos. Outra constatação é que, cada vez mais, a GPR estará preparada para abarcar projetos que, até então, não possuía competência para gerir. Outro fato que merece destaque é o conhecimento que os 
profissionais contratados trazem para dentro da empresa, o que aumenta sua massa especialista com a disseminação e a troca de experiências entre os profissionais.

Quanto a capacitação em softwares, o quadro mostra que a cada projeto a empresa viu-se obrigada a buscar uma nova ferramenta de trabalho, até então desconhecida. No caso da empresa GPR, houve também a preocupação em antecipar-se a uma possível exigência da Petrobras, o que conferiu maior credibilidade à empresa frente aos seus concorrentes.

Se compararmos os 3 projetos, concluiremos que no decorrer deles a GPR tornouse apta a desenvolver projetos utilizando-se de, pelo menos, 5 novas ferramentas.

Embora grande parte do processo tenha sido induzido pela Petrobras, o ganho de experiência e de aprendizagem permanecerá na empresa, o que corrobora com a afirmação de que há grande possibilidade de aumentar sua competitividade perante as demais empresas do setor.

Quanto as rotinas criadas, estas são consideradas as 'saídas' das capacitações dinâmicas, ou seja, o produto após a transformação dos recursos (conhecimento) da empresa.

Outra fonte de aprendizagem e de capacitação é mostrada através da parceria com epecistas, geradas por consequência do acúmulo do conhecimento e das capacitações no decorrer dos projetos.

A tabela 5 trará um resumo do que foi pesquisado em ocasião das entrevistas de campo da fase 2. 
Tabela 5 - Dados dos projetos analisados na GPR

\begin{tabular}{|c|c|c|c|c|c|c|c|c|c|c|c|}
\hline & Título & $\begin{array}{c}\text { Início } \\
\text { (Mês/Ano) }\end{array}$ & $\begin{array}{l}\text { No Pessoal } \\
\text { Especializado }\end{array}$ & $\begin{array}{l}\text { Contratação de } \\
\text { Conhecimento } \\
\text { Especialivado }\end{array}$ & $\begin{array}{l}\text { Contratação de } \\
\text { Serviços de } \\
\text { Consultoria }\end{array}$ & $\begin{array}{l}\text { Softwares } \\
\text { Utilizados }\end{array}$ & $\begin{array}{l}\text { Principais } \\
\text { Rotinas }\end{array}$ & Maior Desafio & $\begin{array}{c}\text { Maior } \\
\text { Aprendizado }\end{array}$ & $\begin{array}{l}\text { Projeto } \\
\text { Gerou } \\
\text { Alianças? }\end{array}$ & $\begin{array}{c}\text { Projeto } \\
\text { Proporcionou } \\
\text { Novos } \\
\text { Clientes? }\end{array}$ \\
\hline Projeto 1 & $\begin{array}{c}\text { Planta para } \\
\text { Carteira de Gás }\end{array}$ & $\begin{array}{c}\text { Outubro } \\
2004\end{array}$ & $\begin{array}{c}18 \\
\text { Engenheiros }\end{array}$ & SMS & $\begin{array}{l}\text { - Estudo } \\
\text { geotécnico; } \\
\text { - Análise de } \\
\text { sistemas elétricos; } \\
\text { - Análise de } \\
\text { flexibilidade. }\end{array}$ & $\begin{array}{l}\text { INtools; } \\
\text { PDMS. }\end{array}$ & $\begin{array}{l}\text { Procedimento } \\
\text { para modelar } \\
\text { tubulação em } \\
\text { 3D }\end{array}$ & $\begin{array}{l}\text { Capacitar as } \\
\text { disciplinas de } \\
\text { engenharia para } \\
\text { trabalhar com } \\
\text { modelagem 3D. }\end{array}$ & $\begin{array}{l}\text { Trabalhar com a } \\
\text { modelagem 3D no } \\
\text { software PDMS. }\end{array}$ & EPC & $\begin{array}{l}\text { Abriu portas } \\
\text { para } \\
\text { modelagem 3D }\end{array}$ \\
\hline Projeto 2 & $\begin{array}{l}\text { FEED para } \\
\text { Carteira de } \\
\text { Propeno }\end{array}$ & $\begin{array}{l}\text { Agosto } \\
2006\end{array}$ & $\begin{array}{c}103 \\
\text { Engenheiros }\end{array}$ & $-*$ & $\begin{array}{l}\text { - Estudo } \\
\text { geotécnico. } \\
\text { - Análise de } \\
\text { sistemas elétricos e } \\
\text { de flexibilidade } \\
\text { feitos com equipe } \\
\text { própria. }\end{array}$ & $\begin{array}{l}\text { - PDMS; } \\
\text { - COMOS p/ } \\
\text { módulo de } \\
\text { elétrica; } \\
\text { - TRIPLEX p/ } \\
\text { flexibilidade }\end{array}$ & $\begin{array}{l}\text { - Procedimento } \\
\text { para modelar } \\
\text { em 3D elétrica, } \\
\text { instrumentação; } \\
\text { - Procedimento } \\
\text { para inclusão } \\
\text { de entidade no } \\
\text { projeto. }\end{array}$ & $\begin{array}{l}\text { Tornar-se } \\
\text { expert na } \\
\text { modelagem 3D } \\
\text { em todas as } \\
\text { disciplinas de } \\
\text { engenharia }\end{array}$ & $\begin{array}{l}\text { - Consolidação da } \\
\text { modelagem 3D } \\
\text { para elétrica e } \\
\text { instrumentação; } \\
\text { - Modelagem 3D } \\
\text { para projetos de } \\
\text { outras empresas. }\end{array}$ & EPC & $\begin{array}{l}\text { Sim, com outras } \\
\text { empresas do } \\
\text { mesmo } \\
\text { segmento. }\end{array}$ \\
\hline Projeto 3 & $\begin{array}{c}\text { Planta para } \\
\text { Carteira de } \\
\text { Gasolina }\end{array}$ & $\begin{array}{l}\text { Julho } \\
2010\end{array}$ & $\begin{array}{c}194 \\
\text { Engenheiros }\end{array}$ & $\begin{array}{c}\text { SMS com } \\
\text { equipe própria }\end{array}$ & Estudo Geotécnico. & $\begin{array}{l}\text { - PDMS; } \\
\text { - TRIPLEX; } \\
\text { - PTW Dapper; } \\
\text { - COMOS. }\end{array}$ & $\begin{array}{l}\text { - Procedimento } \\
\text { para review; } \\
\text { - Criação do } \\
\text { cargo de } \\
\text { Coordenação de } \\
\text { modelagem 3D. }\end{array}$ & $\begin{array}{l}\text { - Alterar o } \\
\text { projeto FEED } \\
\text { descontinuado; } \\
\text { - Adequar-se ao } \\
\text { espaço para } \\
\text { obra; } \\
\text { - Montar/treinar } \\
\text { equipe. }\end{array}$ & $\begin{array}{l}\text { - Desenvolver } \\
\text { cálculo para } \\
\text { puxamento e } \\
\text { ampacidade de } \\
\text { cabos; } \\
\text { - Adaptação das } \\
\text { equipes para } \\
\text { trabalhar em } \\
\text { condições } \\
\text { adversas; } \\
\text { - Projetos com } \\
\text { maior precisão; } \\
\text { Análise de campo } \\
\text { mais detalhadas. }\end{array}$ & EPC & $-*_{-}$ \\
\hline
\end{tabular}

Fonte: Pesquisa de campo. Elaborada pela autora. 


\subsection{APRESENTAÇÃO DA EMPRESA KAT}

A empresa KAT iniciou suas atividades atuando como especialista em projetos de Papel \& Celulose, fornecendo serviços de alta qualidade na área de gerenciamento de projetos e engenharia industrial e atuando em um grande universo de atividades industriais, dentre as quais se destacam: Papel e Celulose, Química, Petroquímica, Petrolífera, Meio Ambiente, Siderurgia, Termoelétrica, Agro Indústria, Mineração e Fertilizantes.

Desde o ano de 2004 a empresa KAT teve seu foco direcionado para o setor de Óleo e Gás, que já dava indícios de grande crescimento do setor nos anos seguintes. Hoje a empresa atua como fornecedora de projetos executivos (ou de detalhamento) principalmente para as empresas do grupo Petrobras, que são responsáveis por cerca de $90 \%$ da receita total da KAT. Com sede em São Paulo, a empresa conta hoje com 465 colaboradores diretos, sendo que 150 são engenheiros das mais diversas especialidades: civil, elétrica, instrumentação, etc.

As entrevistas para a segunda fase da pesquisa na CNC contaram com a participação de 3 respondentes:

\begin{tabular}{c|c|cc}
\hline EMPRESA & $\begin{array}{c}\text { DATA DA } \\
\text { EMTREVISTA }\end{array}$ & \multicolumn{1}{c}{ PARTICIPANTE } & $\begin{array}{c}\text { DURAÇÃO } \\
\text { (HORAS) }\end{array}$ \\
\hline & $\begin{array}{l}\text { Gerente de Negócios } \\
\text { Engenheiro de Instrumentação } \\
\text { Projetista }\end{array}$ & $3: 45$ \\
\hline & $31 / 05 / 2011$ & TEMPO TOTAL & $\mathbf{3} 445$ \\
\hline
\end{tabular}

Quadro 15 - Respondentes da segunda fase da pesquisa na KAT.

Fonte: Autora 


\subsubsection{Relação KAT / PETROBRAS}

Em 2004 a empresa KAT, que já possuía cadastro com a Petrobras, passou a atendê-la de forma mais frequente, concorrendo em projetos maiores e mudando o foco de sua atuação para o segmento óleo e gás.

Um dos fatores que motivou a empresa a adotar esta nova estratégia foi o alto valor pago pelos projetos do setor. Outro ponto de destaque era 0 alto valor $\mathrm{H} / \mathrm{h}$ (Homem/hora) cobrado pelos engenheiros do setor, em função de serem mais preparados/capacitados, o que dificultava a contratação dos profissionais para obras de outros segmentos, que pagavam um valor $\mathrm{H} / \mathrm{h}$ menor.

A especialização da empresa voltada ao setor de óleo e gás, segundo o entrevistado, confere-lhes certa vantagem competitiva frente às demais empresas de serviços de engenharia.

Decidida a crescer com o setor de óleo e gás, a KAT migrou seus esforços para atender a todas as exigências da Petrobras, mudando inclusive sua sede para um prédio comercial que atendesse a todas as exigências de espaço e segurança determinados pela Petrobras. A partir desta decisão, deu-se início a uma grande reestruturação na empresa, que também contou com mudanças tecnológicas, de recursos humanos, e do próprio corpo diretivo da empresa.

Os próximos tópicos serão dedicados a descrever como se dá a preparação da KAT para atender a Petrobras, considerando seu papel indutivo na criação das capacitações dos seus fornecedores.

6.4.1.1 KAT e a mudança na estrutura da empresa

Para atender aos projetos da Petrobras a empresa KAT promoveu uma grande reestruturação interna. Criaram departamentos específicos de qualidade, engenharia 
(elétrica, civil, mecânica, tubulação, química e instrumentação), TI (atualizando hardwares e softwares), comprou a licença de softwares específicos de engenharia utilizados pela Petrobras (PDMS, COMMOS, etc.) e aumentou em $50 \%$ seu quadro de pessoal.

O espaço físico também foi aumentado, ocupando hoje um prédio de 8 andares para acomodar, quando necessário, epecistas e funcionários da própria Petrobras.

Quanto às certificações, a tríplice qualificação (ISO 9.001, ISO 14.001, OHSAS 18.001) é quesito básico para que se possa participar das licitações. Segundo o entrevistado, para atender a todas as normas de qualidade da Petrobras, a empresa KAT desativou um prédio que, por ser antigo, não tinha o sistema de tubulação de ar-condicionado condizente com as normas atuais de segurança. Mesmo com todas as dificuldades enfrentadas, o entrevistado diz concordar com a sistemática rígida da Petrobras.

Por solicitação da Petrobras, e para estar mais perto do Cenpes, a empresa KAT abriu em 2011 um novo escritório na cidade do Rio de Janeiro. Este escritório possui especialistas das disciplinas de engenharia e um pequeno centro de TI. No decorrer do ano, conforme citou o Gerente de Negócios, a empresa espera aumentar a estrutura.

\subsubsection{KAT e a competência técnica}

Para continuar alavancando novos negócios, a KAT tem a preocupação de sempre melhorar seus serviços, aumentando sua qualidade, capacidade técnica e competência profissional. Para isso, a empresa contrata engenheiros recémformados (principalmente navais) ou tecnólogos e prepara-os para atuarem na Petrobras, principalmente como especialistas em instalação / manutenção de plataformas. 
A KAT destina parte da porcentagem de seu faturamento para investimento interno em capacitações. Seu corpo diretivo é fortemente engajado em treinar o pessoal interno para atuarem em projetos da Petrobras.

Segundo cita o Gerente de Negócios, "a empresa tem pessoas chave para atuar em cada software, sendo responsáveis, também, por treinar o pessoal externo que, por ventura, seja contratado em regime de terceirização".

A empresa busca antecipar-se às exigências da Petrobras. Sempre que há uma sinalização da Petrobras de que algo será necessário e/ou exigido de seus fornecedores, seja software ou mão-de-obra específica, a KAT busca aprender e criar a competência na empresa, de forma que o conhecimento possa ser compartilhado nas equipes.

A KAT criou internamente um grupo dedicado aos softwares Petrobras. Para capacitar o grupo na atuação com o COMOS, a empresa esteve no Cenpes e solicitou autorização para fazer um projeto piloto utilizando o COMOS. Segundo o Gerente de Negócios, a Petrobras cede a licença para utilização do software e o banco de dados, porém todo o treinamento fica por conta da empresa usuária. Hoje existe na KAT uma equipe de especialistas treinados, não só para trabalhar com os softwares dedicados aos projetos da Petrobras, mas também para disseminar o conhecimento internamente, através de cursos oferecidos pela empresa.

Para a realização de atividades que estão além das suas capacitações, a KAT costuma contratar serviços de consultoria específica, porém, para o caso onde há tempo hábil, a prioridade é que se criem as capacitações internamente. Tudo dependerá da variável "tempo".

Visando desenvolver suas competências internamente, a empresa contrata estagiários das disciplinas de engenharia e passa a treiná-los para atuar no setor de óleo e gás. Ao final do curso, os estagiários são contratados pela empresa. 


\subsubsection{KAT e as subcontratações}

Para atender ao escopo dos projetos da Petrobras, cabe à empresa de serviços de engenharia buscar caminhos para a realização de atividades que estejam fora da sua capacitação. Desta forma, sempre que necessário, a KAT contrata mão-de-obra terceirizada e serviços de consultoria para a realização de estudos e análises específicas, cuja competência ainda não tenha sido desenvolvida internamente.

A contratação externa não exime a KAT da responsabilidade pela execução e pelo resultado final dos projetos. Desta forma, os serviços terceirizados também devem obedecer aos critérios de competência e confiabilidade ditadas pela Petrobras.

Esta prática requer da empresa de serviços de engenharia total responsabilidade por qualquer serviço prestado à Petrobras, o que reflete em certos padrões de qualidade por parte da subcontratada. Primar pela qualidade e pontualidade são fatores indispensáveis na escolha de um subcontratado pela empresa de engenharia.

É possível perceber que as exigências da Petrobras extrapolam a cadeia de fornecedores diretos, indo além das fronteiras de seu sistema de cadastro. Segundo citou o Gerente de Negócios "o maior aprendizado que ocorreu após os contratos de parceria com a Petrobras foi a busca pela qualidade total, não só nos projetos, mas principalmente nos padrões de trabalho da empresa".

Na sequência serão descritos os três projetos analisados na CNC, bem como suas particularidades:

\subsubsection{Projeto 1 - Planta para carteira de gasolina}

O projeto 1 foi desenvolvido em dezembro/2007. Para a execução deste projeto, a GPR contou com a participação de 45 engenheiros diretos. 
Para este projeto foi firmado um consórcio com outras duas empresas. Houve a mobilização da equipe de projeto numa estrutura separada, onde foi criado um escritório que permitisse a mobilização dos recursos do projeto numa mesma estrutura, evitando inclusive os rateios. Vale ressaltar que esta prática de trabalho não foi adotada pela KAT para todos os projetos.

Este foi o primeiro grande projeto da KAT com a Petrobras, partindo do ponto de vista do impacto estrutural e de aprendizagem. O maior desafio do projeto foi aprender a trabalhar como epecista, ou seja, conduzir o projeto considerando toda a burocracia e a qualidade de execução exigida pela Petrobras na qualidade de epecista que, neste caso, responde pelo sucesso total da obra.

Outro desafio foi gerenciar a empresa de engenharia consultiva contratada. Neste projeto a KAT subcontratou outra empresa do mesmo segmento - PJC - que, desta vez, faria o projeto de engenharia consultiva. Esta foi a primeira vez que se dividiu um serviço de engenharia num mesmo projeto, o que também foi um grande desafio. A equipe de engenharia consultiva foi composta por $50 \%$ de pessoal da KAT e $50 \%$ da PJC.

Em função desta situação, a KAT criou, junto à sua equipe de $\mathrm{Tl}$, uma nova ferramenta de gestão: o PGSE (Procedimento para Gestão de Serviços de Engenharia), que consistia em analisar quais serviços caberiam a cada empresa, além de demonstrar a situação cronológica de cada atividade (antecipada, em dia, atrasada). Outro procedimento adotado foi a análise detalhada de data sheets (folhas de dados) dos equipamentos, através de uma equipe composta por 6 engenheiros especialistas das diversas disciplinas da engenharia.

A contratação deste projeto rendeu muita maturidade gerencial à KAT, pois, além de passar a enxergar uma concorrente como aliada, a PJC trouxe a sua cultura, sua forma de trabalho e isso exigiu uma adaptação de ambas às empresas na condução do projeto. A adaptação foi difícil no início, pois havia diferenças técnicas, diferença de metodologia de trabalho, de cultura organizacional, etc., de forma que, para a KAT, foi um grande aprendizado. 
Criar procedimentos, na opinião do Gerente de Negócios, ajuda a diminuir a quantidade de erros no projeto, uma vez que há regras pré-estabelecidas para a execução dos trabalhos. Quanto às atividades de engenharia e de projeto, já que são rotinas básicas das duas empresas, não fogem muito das habilidades e isso facilita a gestão.

Normalmente, a empresa de serviços de engenharia responsável pelo escopo da disciplina é que impõe a sua filosofia. Neste caso, além da gerência geral (KAT como epecista), houve a necessidade de destacar um gerente em cada empresa para o acompanhamento do projeto e a troca de informações.

Para desenvolver o projeto 1 , a empresa KAT contou com serviços de consultoria de profissionais e empresas detentoras de vasta experiência:

- Análise de solo;

- Sondagem;

- Análise de flexibilidade;

- Consultoria para a tríplice classificação empresarial em sistema de gestão da qualidade (ISO 9.001); de meio ambiente (ISO 14.001); e de saúde e segurança no trabalho (OHSAS 18.001).

Não houve a contratação de competências gerenciais ou técnicas, todas foram desenvolvidas internamente, por isso este projeto foi considerado um marco, pois foi uma grande escola para a KAT.

Planejamento e qualidade sempre foram o principal foco da KAT, que hoje tem total conforto em trabalhar com a Petrobras devido ao aprendizado neste projeto.

Criou-se, também, o grupo denominado CÉU, que reúne profissionais de diversas áreas da empresa (comercial, recursos humanos, disciplinas de engenharia) para 
discutir, mensalmente, os avanços em cada área da empresa. O intuito é trazer ao conhecimento dos líderes o cenário de cada área da empresa num dado momento.

Quanto aos softwares utilizados, além dos aplicativos de engenharia, houve a necessidade de utilização dos softwares PRIMAVERA e PDMS, até então desconhecidos pela KAT. Quanto ao PDMS, tanto a equipe da KAT quanto a equipe da PJC, foram treinadas externamente. Quanto ao software PRIMAVERA, houve a contratação de profissionais especialistas, que passaram a integrar a equipe da KAT, sendo responsáveis pela disseminação do conhecimento internamente.

- PDMS - Software com aplicação tridimensional, conforme já descrito;

- PRIMAVERA - Software de gestão comercial.

Tendo sido o primeiro projeto significante da KAT com a Petrobras, e devido ao seu sucesso, este serviu com um marco para a empresa se engajar em outros projetos com a Petrobras, o que lhes conferiu maior destaque no mercado.

\subsubsection{Projeto 2 - FEED para carteira de diesel}

O projeto 2 foi desenvolvido em abril/2009. Para a execução deste projeto, a KAT contou com a participação de 92 engenheiros diretos.

$\mathrm{O}$ projeto FEED (Front and Engineering Design) é uma modalidade de projeto adotada pela Petrobras, cujo objetivo é analisar a consistência do projeto básico e estimar o valor do total da obra. Consiste também do pré-detalhamento do projeto executivo. Cabe ao FEED efetuar um levantamento prévio da média de custos dos projetos.

Trabalhar a expectativa do cliente, que deseja apenas um projeto FEED, e trabalhar a expectativa do engenheiro na sua execução foi um grande aprendizado neste projeto. Além disso, "a coordenação da gerência deve ser muito boa para que os 
engenheiros não gastem horas desnecessárias por tentar fazer um projeto mais complexo, como é o caso dos projetos executivos" (Gerente de Negócios).

Nos projetos do tipo FEED, a Petrobras exige de tempos em tempos um relatório de ocorrências, que deve ser preenchido pela empresa de engenharia. O interesse da KAT era que, além do preenchimento correto, o relatório fosse enviado com informações que servissem de argumento para cada dificuldade encontrada.

Foi então que a KAT adotou como procedimento o ROP (Relatório de Ocorrências do Projeto), uma ferramenta que visa à formalização de todas as atividades que evoluíram durante as reuniões de projeto (documentação gerencial, registros, etc.) com a Petrobras. "No caso de haver a necessidade de prorrogação no prazo de entrega ou a renegociação de uma atividade, o ROP apontará onde houve a falha que gerou a necessidade da solicitação" (Gerente de Negócios).

Tal procedimento trouxe benefícios, pois a empresa KAT passou a ter controle sobre todas as informações trocadas com a Petrobras, conforme citou o Gerente de Negócios:

"Queríamos criar um procedimento para a formalização de todas as informações trocadas com a Petrobras para que, no caso de haver necessidade de prorrogação no prazo do projeto ou de um adendo de valor, os motivos pudessem ser apresentados formalmente. Isso nos possibilitou ser atendidos sem tantos questionamentos e não tivemos nenhuma recusa. São registros de ocorrência semanal, com assinatura do cliente. Esta rotina que não era obrigatória, e sim solicitada pela Petrobras para projetos FEED, mas passou a ser obrigatória na KAT."

Outro procedimento adotado pela empresa foi uma ferramenta denominada GED (Gerenciamento Eletrônico de Documentos) - Trata-se de um software que capacita as empresas a gerenciar arquivos eletrônicos como imagens, faxes, e-mails, e outros arquivos durante os estágios do gerenciamento das informações. Trata-se de um sistema modular que permite customizar a solução de acordo com as 
necessidades de cada empresa, fornecendo captura, gerenciamento de documentos e registros, arquivamento, integração, recuperação e distribuição de arquivos.

Para a execução deste projeto não houve a contratação de serviços de consultoria. Tanto a análise de flexibilidade quanto a tríplice classificação empresarial em sistema de gestão da qualidade (ISO 9.001); de meio ambiente (ISO 14.001); e de saúde e segurança no trabalho (OHSAS 18.001), foram feitas por equipe desenvolvida internamente.

Quanto aos softwares utilizados, além dos aplicativos de engenharia, houve a necessidade de utilização dos seguintes softwares:

- PDMS - Software com aplicação tridimensional, conforme já descrito;

- PRIMAVERA - Software de gestão comercial.

Após a execução deste projeto FEED, a Petrobras indicou a KAT para mais 3 contratos com empresas epecistas. Segundo citou o Gerente de Negócios "isso foi motivo de muita alegria, pois, embora o preço da KAT não seja o menor da categoria, e levando-se em conta que há projetistas mais baratos, a Petrobras fez a recomendação devido à confiabilidade nos serviços já prestados".

Este projeto trouxe à KAT uma grande experiência técnico/gerencial, pois todo o gerenciamento foi feito por ela.

\subsubsection{Projeto 3 - Planta para carteira de enxofre}

O projeto 3 da KAT teve início em janeiro/2011. Para execução deste projeto, a KAT contou com a participação de 103 engenheiros diretos. 
A participação da KAT no projeto 3 deu-se através da contratação da empresa por um consórcio firmado por 2 epecistas. Coube à KAT desenvolver o projeto executivo para a obra da planta para carteira de enxofre da Petrobras.

No projeto 3 ocorreu a consolidação da empresa quanto ao diligenciamento da gestão de fornecedores, visto a vasta experiência acumulada durante os projetos com a Petrobras.

A empresa optou por criar novas ferramentas para o auxílio no gerenciamento dos projetos, principalmente os projetos que envolviam outras empresas, além da Petrobras. Criaram então o procedimento denominado GISA (Gestão Integrada de Sistemas de Arquivo). Trata-se de um software que trabalha com a lista de materiais gerada no COMOS, porém atua como um organizador de compras para que não seja comprado material em duplicidade, para que os materiais sejam comprados no prazo certo, de acordo com a obra, e principalmente, para que não faltem materiais na obra. A Petrobras também se utiliza desta ferramenta através de um acesso remoto.

A filosofia da empresa KAT, levada à risca pela empresa, determina que "tempo é dinheiro". Em se tratando de Petrobras, essa filosofia é ainda mais importante. Segundo o Gerente de Negócios, a Petrobras paga por medição da obra, ou seja, "quando menos tempo de perde, mais rápido vemos o dinheiro".

A empresa criou o que chamou de stand-up meeting (reunião em pé). Trata-se da reunião de fechamento de pauta da semana, em que todos os gerentes das disciplinas de engenharia se reúnem para debater pontos fortes e fracos em seus projetos. A troca de informações nesta reunião é considerada imprescindível para 0 bom gerenciamento dos projetos: "Há casos em que a dificuldade de um profissional já foi superada por outro, então ocorre uma troca de informações que levam à uma solução mais rápida para os problemas" (Engenheiro de Instrumentação).

Para desenvolver o projeto 3 , a empresa KAT contou com serviços de consultoria de profissionais e empresas detentoras de vasta experiência: 
- Análise de solo;

- Sondagem;

Tanto a análise de flexibilidade quanto a tríplice classificação empresarial em sistema de gestão da qualidade (ISO 9.001); de meio ambiente (ISO 14.001); e de saúde e segurança no trabalho (OHSAS 18.001), foram feitas por equipe desenvolvida internamente.

Quanto aos softwares utilizados, além dos aplicativos de engenharia, houve a necessidade de trabalhar com os softwares PDMS, PRIMAVERA e GED, já conhecidos da empresa.

Quanto ao COMOS, software exigido pela Petrobras, a KAT já havia desenvolvido a capacitação através de um teste piloto realizado no Cenpes, conforme citado no tópico 6.4.1.2.

A KAT especializou-se na plataforma 3D do software COMOS e agregou sua utilização em todos os projetos, mesmo os que não estabeleciam a necessidade de modelagem em 3D. Esta prática conferiu à empresa maior qualidade na apresentação dos seus projetos, o que foi percebido por clientes de outros segmentos, principalmente papel e celulose.

\subsubsection{A criação de capacitações dinâmicas pela KAT}

A criação de capacitações dinâmicas pela KAT poderá ser vista sob dois aspectos.

O primeiro aspecto diz respeito aos mecanismos de aprendizagem de Zollo e Winter (2002), conforme será sintetizado no quadro 16.

Além da reestruturação da empresa, que pode ser verificada através de informações como mudança da estrutura física para uma nova sede, a abertura de um novo 
escritório no Rio de Janeiro, a reestruturação do departamento de TI, com a compra de novas máquinas, novas licenças e softwares e a contratação de pessoal especializado, há que se considerar o avanço da empresa nas práticas gerenciais adotadas para atender a Petrobras.

Um novo conceito de trabalho foi adotado, mais voltado à especialização dos profissionais e ao aumento da qualidade dos projetos.

\section{MECANISMOS DE APRENDIZAGEM - KAT}

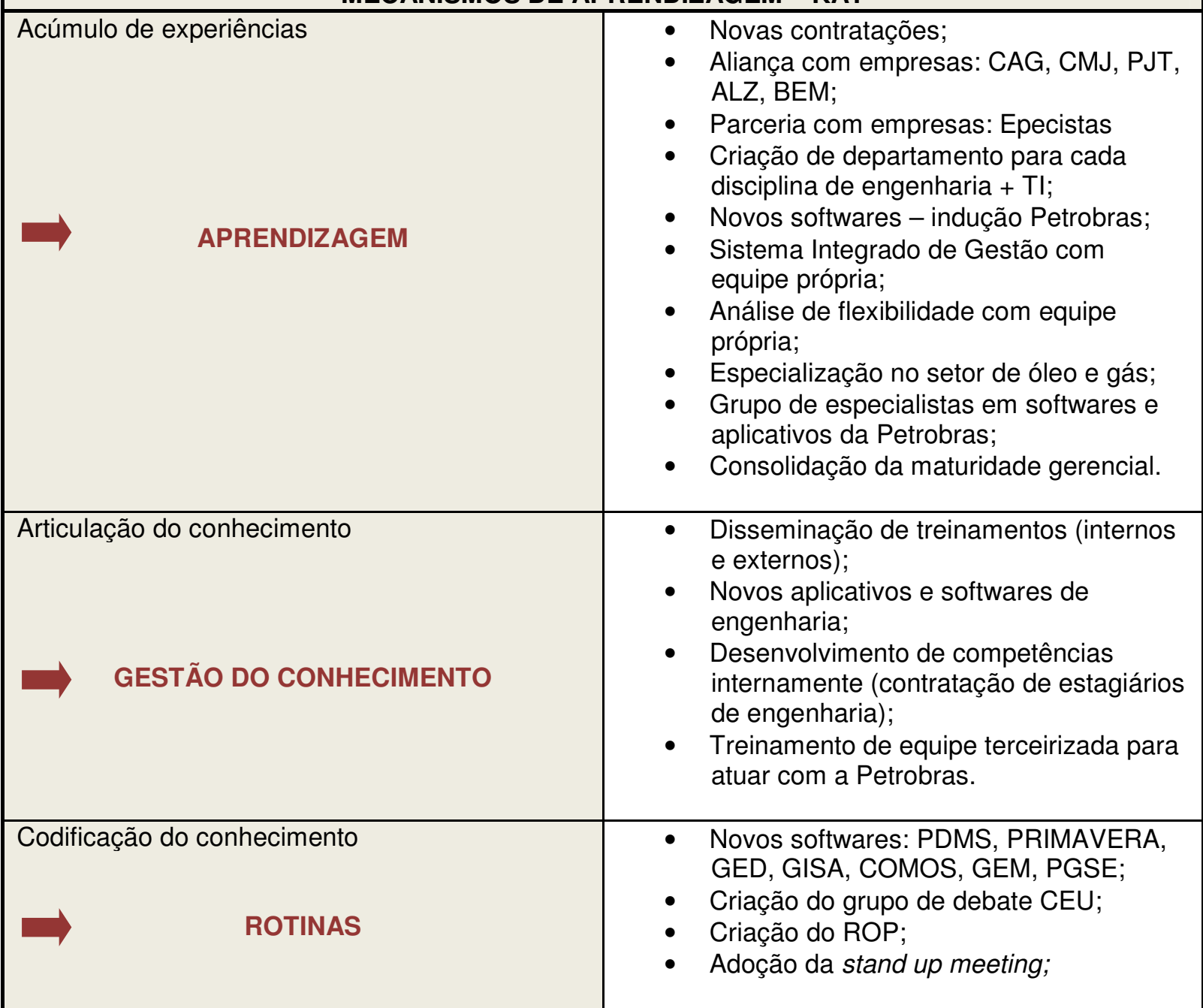

Quadro 16 - Mecanismos de aprendizagem KAT

Fonte: Autora

segundo aspecto diz respeito aos indicadores destacados em cada projeto, a fim de evidenciar a evolução das capacitações da empresa. Serão considerados os 
seguintes indicadores: número de engenheiros envolvidos; número de softwares utilizados (aprendidos); número de rotinas ou procedimentos criados e alianças com outras empresas, conforme será sintetizado no quadro 17.

\begin{tabular}{|c|c|c|c|}
\hline $\mathbf{K A T}$ & $\begin{array}{c}\text { PROJETO } 1 \\
\text { Dezembro/2007 }\end{array}$ & $\begin{array}{c}\text { PROJETO } 2 \\
\text { Abril/2008 }\end{array}$ & $\begin{array}{c}\text { PROJETO } 3 \\
\text { Janeiro/2011 }\end{array}$ \\
\hline $\begin{array}{l}\text { NÚMERO DE } \\
\text { ENGENHEIROS }\end{array}$ & 45 & 92 & 103 \\
\hline $\begin{array}{l}\text { CAPACITAÇÃO EM } \\
\text { SOFTWARES }\end{array}$ & $\begin{array}{l}\text { - PDMS; } \\
\text { - PRIMAVERA; } \\
\text { - PGSE. }\end{array}$ & • GED. & $\begin{array}{l}\text { - COMOS; } \\
\text { - GISA; } \\
\text { - GEM. }\end{array}$ \\
\hline ROTINAS CRIADAS & $\begin{array}{l}\text { - Procedimento para } \\
\text { gerenciamento de } \\
\text { engenharia de } \\
\text { terceiros; } \\
\text { - Procedimento para } \\
\text { análise detalhada } \\
\text { de data sheet de } \\
\text { equipamentos. }\end{array}$ & $\begin{array}{l}\text { - Implantação do } \\
\text { ROP; } \\
\text { - Reunião semanal } \\
\text { para acompanhar } \\
\text { projetos. }\end{array}$ & $\begin{array}{l}\text { - Consolidação do } \\
\text { diligenciamento da } \\
\text { gestão de } \\
\text { fornecedores; } \\
\text { - Reunião stand up } \\
\text { meeting. } \\
\text { - Criação da equipe } \\
\text { de especialistas } \\
\text { nos softwares da } \\
\text { Petrobras; } \\
\text { - SMS com equipe } \\
\text { própria. }\end{array}$ \\
\hline $\begin{array}{c}\text { ALIANÇAS COM } \\
\text { OUTRAS EMPRESAS }\end{array}$ & $\begin{array}{ll}\text { - } & \text { EPC; } \\
\text { - } & \text { CAG; } \\
\text { - } & \text { CMJ; } \\
\text { - } & \text { PJT. }\end{array}$ & - EPC. & $\begin{array}{l}\text { - EPC; } \\
\text { - ALZ; } \\
\text { - BEM. }\end{array}$ \\
\hline
\end{tabular}

Quadro 17 - Indicadores de capacitação dinâmica - KAT

Fonte: Autora

O quadro 17 mostra que houve aumento crescente no número de engenheiros especialistas. Esta constatação pode significar o aumento das dificuldades técnicas e dos riscos que envolvem os projetos. Outra constatação é que, cada vez mais, a KAT estará preparada para abarcar projetos que, até então, não possuía competência para gerenciar. 
Outro fato que merece destaque é o conhecimento que os profissionais contratados trazem para dentro da empresa, o que aumenta sua massa especialista com a disseminação e a troca de experiências entre os profissionais.

A KAT demonstra estar cada vez mais preparada para gerenciar os projetos de porte da Petrobras. Fato que merece destaque é o conhecimento que os profissionais contratados trazem para dentro da empresa, o que aumenta sua massa especialista com a disseminação e a troca de experiências entre os profissionais.

Quanto à capacitação em softwares, ficou clara a preocupação da empresa KAT em desenvolver ferramentas de gestão para minimizar os riscos e erros nos projetos da Petrobras. Estas ferramentas são utilizadas em toda a estrutura da empresa, o que extrapola o conhecimento para outros clientes do segmento de óleo e gás. Se compararmos os 3 projetos, concluiremos que no decorrer deles a GPR tornou-se apta a desenvolver projetos utilizando-se de 7 novas ferramentas.

Quanto às rotinas criadas pela KAT, estas demonstram a grande preocupação da empresa com a gestão dos seus projetos. Este parece ser o principal foco da empresa.

Outra fonte de aprendizagem e de capacitação é mostrada através das alianças e/ou parcerias geradas por consequência do acúmulo do conhecimento e das capacitações no decorrer dos projetos. Os três projetos analisados na KAT renderam alianças com outras empresas, além de contratos com novos clientes, embora as empresas não tenham sido citadas.

Ser fornecedor da Petrobras significa, perante o mercado, ser capacitado a desenvolver projetos com a qualidade e a confiabilidade exigida pelas empresas de porte, o que remete as empresas de serviços de engenharia que atendem a Petrobras a um patamar diferenciado no setor.

A tabela 6 trará um resumo do que foi pesquisado em ocasião das entrevistas de campo da fase 2. 
Tabela 6 - Dados dos projetos analisados na KAT

\begin{tabular}{|c|c|c|c|c|c|c|c|c|c|c|c|}
\hline & Título & $\begin{array}{c}\text { Início } \\
\text { (Mês/Ano) }\end{array}$ & $\begin{array}{l}\text { No Pessoal } \\
\text { Especializado }\end{array}$ & $\begin{array}{l}\text { Contratação de } \\
\text { Conhecimento } \\
\text { Especializado }\end{array}$ & $\begin{array}{l}\text { Contratação de } \\
\text { Serviços de } \\
\text { Consultoria }\end{array}$ & $\begin{array}{l}\text { Softwares } \\
\text { Utilizados }\end{array}$ & Principais Rotinas & $\begin{array}{l}\text { Maior } \\
\text { Desafio }\end{array}$ & $\begin{array}{c}\text { Maior } \\
\text { Aprendizado }\end{array}$ & $\begin{array}{c}\text { Projeto } \\
\text { Gerou } \\
\text { Alianças? }\end{array}$ & $\begin{array}{c}\text { Projeto } \\
\text { Proporcionou } \\
\text { Novos } \\
\text { Clientes? }\end{array}$ \\
\hline Projeto 1 & $\begin{array}{l}\text { Planta para } \\
\text { Carteira de } \\
\text { Gasolina }\end{array}$ & $\begin{array}{l}\text { Dezembro } \\
2007\end{array}$ & $\begin{array}{c}45 \\
\text { Engenheiros }\end{array}$ & SMS & $\begin{array}{l}\text { - Análise de } \\
\text { solo; } \\
\text { - Sondagem; } \\
\text { - Análise de } \\
\text { flexibilidade. }\end{array}$ & $\begin{array}{l}\text { - PDMS; } \\
\text { - PRIMAVERA } \\
\text { (Software de } \\
\text { planejamento); } \\
\text { - PGSE. }\end{array}$ & $\begin{array}{l}\text { - Procedimento para } \\
\text { gerenciar serviços } \\
\text { de engenharia } 3^{\mathrm{a}} ; \\
\text { - Procedimento para } \\
\text { análise detalhada de } \\
\text { data sheet de } \\
\text { equipamentos. }\end{array}$ & $\begin{array}{l}\text { - Conduzir } \\
\text { projeto com } \\
\text { outra empresa } \\
\text { de engenharia } \\
\text { consultiva; } \\
\text { - Burocracia e } \\
\text { execução na } \\
\text { qualidade de } \\
\text { EPCista. }\end{array}$ & $\begin{array}{l}\text { - Gerenciar } \\
\text { projetos com } \\
\text { diversas } \\
\text { empresas; } \\
\text { - Criar } \\
\text { procedimentos } \\
\text { ajuda a diminuir } \\
\text { erros. }\end{array}$ & $\begin{array}{l}\text { CAG } \\
\text { CMJ } \\
\text { PJT }\end{array}$ & $\begin{array}{l}\text { Sim, mas não } \\
\text { informa } \\
\text { empresa. }\end{array}$ \\
\hline Projeto 2 & $\begin{array}{l}\text { FEED para } \\
\text { Carteira de } \\
\text { Diesel }\end{array}$ & $\begin{array}{l}\text { Abril } \\
2009\end{array}$ & $\begin{array}{c}92 \\
\text { Engenheiros }\end{array}$ & $\begin{array}{c}\text { SMS com } \\
\text { Equipe Própria }\end{array}$ & $-*_{-}$ & $\begin{array}{l}\text { - PDMS; } \\
\text { - PRIMAVERA } \\
\text { (>maturidade); } \\
\text { - GED (gestão } \\
\text { eletrônica de } \\
\text { documentos). }\end{array}$ & $\begin{array}{l}\text { - Implantação do } \\
\text { ROP Relatório de } \\
\text { Ocorrência de } \\
\text { Projeto; } \\
\text { - Reunião semanal } \\
\text { para acompanhar os } \\
\text { projetos. }\end{array}$ & $\begin{array}{l}\text { - Trabalhar } \\
\text { expectativa } \\
\text { do cliente e } \\
\text { funcionários } \\
\text { - projeto era } \\
\text { estratégico }\end{array}$ & $\begin{array}{l}\text { - Experiência } \\
\text { técnica / } \\
\text { gerencial; } \\
\text { - Criação de } \\
\text { rotinas para } \\
\text { aplicação em } \\
\text { outros projetos / } \\
\text { clientes. }\end{array}$ & $-*_{-}$ & $\begin{array}{l}\text { Sim, } 3 \text { projetos } \\
\text { com grandes } \\
\text { EPCistas - por } \\
\text { indicação da } \\
\text { Petrobras }\end{array}$ \\
\hline Projeto 3 & $\begin{array}{l}\text { Planta para } \\
\text { Carteira de } \\
\text { Enxofre }\end{array}$ & $\begin{array}{l}\text { Janeiro } \\
2011\end{array}$ & $\begin{array}{c}103 \\
\text { Engenheiros }\end{array}$ & $\begin{array}{c}\text { SMS com } \\
\text { Equipe Própria }\end{array}$ & $\begin{array}{l}\text { - Análise de } \\
\text { solo; } \\
\text { - Sondagem; } \\
\text { - Análise de } \\
\text { flexibilidade } \\
\text { desenvolviment } \\
\text { o próprio. }\end{array}$ & $\begin{array}{l}\text { - PRIMAVERA; } \\
\text { - GED; } \\
\text { - COMOS; } \\
\text { - GISA; } \\
\text { - GEM }\end{array}$ & $\begin{array}{l}\text { - Agregada a equipe } \\
\text { de especialistas em } \\
\text { software Petrobras; } \\
\text { - Consolidação do } \\
\text { diligenciamento da } \\
\text { gestão de } \\
\text { fornecedores; } \\
\text { - Nova forma de } \\
\text { reunião: menor } \\
\text { tempo x maior foco } \\
\text { (em pé). }\end{array}$ & $\begin{array}{l}\text { - Utilização } \\
\text { do software } \\
\text { COMOS; } \\
\text { - GEM } \\
\text { (Gestão } \\
\text { elétrica de } \\
\text { materiais) }\end{array}$ & $\begin{array}{l}\text { - SMS com } \\
\text { equipe própria; } \\
\text { - Análise de } \\
\text { flexibilidade com } \\
\text { equipe própria; } \\
\text { - Avanço na } \\
\text { modelagem 3D. }\end{array}$ & $\begin{array}{l}\text { ALZ } \\
\text { BEM }\end{array}$ & $-*_{-}$ \\
\hline
\end{tabular}

Fonte: Pesquisa de campo. Elaborada pela autora. 


\subsection{SÍNTESE}

Os casos analisados na fase 2 nos permite algumas conclusões sobre a capacitação das empresas de serviços de engenharia que atuam no mercado via contratos com a Petrobras. As empresas entrevistadas, sem exceção, demonstram grande preocupação em atender às exigências da Petrobras. Em todos os casos foi possível identificar:

- Aumento na estrutura física da empresa;

- Aumento do número de contratações de engenheiros especialistas;

- Agregação de novas competências, antes contratadas externamente;

- Aumento na capacitação dedicada aos softwares com modelagem tridimensional (PDMS e COMOS);

- Formação de equipes especialistas em projetos da Petrobras;

- Aumento na criação de rotinas administrativas e operacionais;

- Formação de alianças com outras empresas devido a visibilidade proporcionada pela atuação em projetos da Petrobras;

- Entre outras...

Ao analisar o perfil das empresas visitadas, considerando as ações dedicadas a cada projeto analisado, é possível afirmar que cada empresa demonstra maior preocupação com o desenvolvimento de uma determinada área do conhecimento:

CNC - Demonstrou preocupação com o conhecimento técnico da empresa, no que tange as disciplinas de engenharia;

GPR - Demonstrou preocupação com o conhecimento tecnológico da empresa, no que tange as ferramentas de $\mathrm{Tl}$;

KAT - Demonstrou preocupação com a gestão da empresa, no que tange as ferramentas desenvolvidas para auxiliar a gestão dos projetos. 


\section{RESULTADOS}

Além dos resultados alcançados por empresa, conforme mostrado no capítulo 6 , se retomarmos os conceitos do referencial teórico será possível identificar algumas evidências da literatura que se aplicam aos estudos de caso apresentados.

Sendo o indivíduo considerado a unidade de análise da aprendizagem organizacional, conforme cita Easterby-Smith, Crossan e Nicolini (2000), é possível afirmar que as empresas de serviços de engenharia aumentaram sua capacidade de aprendizagem devido ao aumento no número de contratações, principalmente de profissionais especialistas.

Também foi possível notar que as empresas visitadas utilizam-se do mecanismo de 'especialização' para facilitar a aprendizagem, conforme citam Levinthal e March (1993). A especialização pode ser percebida em todos os projetos analisados, visto a grande concentração de competências restritas, o que, em muitos casos, levou as empresas a contratarem serviços de consultoria.

Outra forma de aprendizagem percebida vem corroborar com o conceito de DUI (Doing, Using and Interacting), de Jensen et al. (2007). A forma DUI baseia-se na experiência e é o modo de aprendizagem baseado em Fazer, Usar e Interagir, o que pode ser conferido na troca de experiências entre os profissionais mais experientes com os menos experientes durante cada projeto.

Quanto a estratégia de aprendizagem, conforme citam Mintzberg, Ahlstrand e Lampel (2000), a forma percebida nas empresas visitadas foi a 'deliberada', ou seja, planejada e formuladas por líderes tendo em vista o papel indutor da Petrobras.

Com base nas ideias de Scarbrough et al. (2004), é possível afirmar que grande parte da aprendizagem ocorre através dos projetos feitos para a Petrobras, pois foi possível identificar as ligações entre aprendizagem intra-projeto e a transferência da aprendizagem para a organização, promovendo a integração do conhecimento. 
No caso de fusões, aquisições ou parcerias entre empresas, mais uma vez é possível afirmar que a aprendizagem através dos projetos com a Petrobras conferem às empresas de serviços de engenharia uma estratégia competitiva, visando o aumento da competência das empresas através da transição da eficiência isolada para a eficiência coletiva (FLEURY; FLEURY, 2003). É o que Winkelen (2010) chama de 'Aprendizado Colaborativo'.

Quanto a Gestão do Conhecimento, as empresas apresentaram ferramentas como intranets, banco de dados, os repositórios de conhecimento, criação de diretórios de especialização, além de outros sistemas de informação aplicados a gestão do conhecimento, o que confirma a perspectiva de gestão voltada á 'informação', citada por Alavi e Leidner (2001).

A adoção de estruturas organizacionais respaldadas por sistemas de softwares específicos são essenciais para captar, focalizar e alavancar ao máximo suas capacidades como o conhecimento, as habilidades intelectuais e a experiência acumulada. Também reforça o vínculo dos profissionais com a organização, proporcionando-Ihes banco de dados, modelos analíticos e maior capacidade de troca de informações, o que capacita os profissionais a estender seu desempenho muito além de seus limites pessoais.

Outra forma de gestão e transferência do conhecimento percebida foi o programa de treinamento, encontrado nas 3 empresas visitadas, o que garante a aprendizagem e a transferência de informações como um meio de aumentar a base de conhecimento dos trabalhadores (WELDY; 2009, BATES; 2001; GEPHART et al., 1996).

Como forma de estocagem do conhecimento específico, muitas rotinas foram encontradas na empresa, tendo sido destacadas aquelas criadas por consequência dos projetos analisados (NELSON; WINTER, 2005). As capacitações dinâmicas podem ser visualizadas através do processo de transformação de recursos e do conhecimento da empresa nessas rotinas.

Foi detectado, através dos entrevistados, que a Petrobras preza tanto por aspectos formais (softwares e rotinas) quanto por conhecimento tácito (desenvolvimento e 
atuação em projetos executados). No caso das empresas de serviços de engenharia, cujo produto é uma 'solução' buscada por um cliente, o intelecto profissional cria boa parte do valor da empresa, o que remete a figura do indivíduo a um patamar estratégico (QUINN; ANDERSON; FINKELSTEIN, 1996).

O próximo capítulo trará as conclusões da pesquisa, suas limitações e sugestões para pesquisa futura. 


\section{CONCLUSÕES}

Neste capítulo serão apresentadas as principais conclusões desta pesquisa, com base nos resultados da análise dos capítulos 6 e 7. Trataremos da questão da pesquisa e das hipóteses, que serão confrontadas com os resultados alcançados. $O$ capítulo também prevê a consideração das limitações da pesquisa e as sugestões para pesquisas futuras, que visam à ampliação do conhecimento acerca das empresas de serviços de engenharia.

Ao realizar uma análise global dos estudos de caso, considerando os resultados obtidos nas 2 fases de pesquisa, é possível afirmar que as empresas de serviços de engenharia que atuam no mercado, via contratos com a Petrobras, possuem capacitações que Ihes conferem maior qualidade nos serviços prestados. Essa afirmativa pode ser atribuída dois fatores:

$\checkmark$ O primeiro diz respeito à preocupação das empresas entrevistadas em buscar, continuamente, melhorar os serviços prestados, seja através do aumento da sua estrutura física, seja através do aumento das suas capacitações técnicas, gerenciais e competências profissionais.

$\checkmark$ O segundo refere-se ao fato de que a Petrobras é vista no mercado como uma empresa padrão de referência quanto às normas de trabalho exigidas aos seus fornecedores. Desta forma, é conferido às empresas de serviços de engenharia que atendem à Petrobras, certo grau de confiabilidade e destaque no mercado frente às demais empresas do setor.

Embora todas as empresas tenham apresentado características parecidas quanto ao aumento das capacitações dinâmicas, através da criação de rotinas e procedimentos de trabalho, foi possível perceber que cada empresa demonstra maior preocupação com o desenvolvimento de uma determinada área do conhecimento: 
CNC - Demonstrou preocupação com o conhecimento técnico da empresa, no que tange as disciplinas de engenharia;

GPR - Demonstrou preocupação com o conhecimento tecnológico da empresa, no que tange as ferramentas de $\mathrm{Tl}$;

KAT - Demonstrou preocupação com a gestão da empresa, no que tange as ferramentas desenvolvidas para auxiliar a gestão dos projetos.

Esta percepção nos faz concluir que, embora a relação com a Petrobras seja dotada de alto teor burocrático, há espaço para que as empresas de serviços de engenharia possam moldar sua estrutura técnica e administrativa, adotando práticas de atuação e gestão que possam conferir-Ihes maior vantagem competitiva.

\subsection{CONFRONTANDO HIPÓTESES E RESULTADOS}

Para responder à questão da pesquisa foram identificadas duas proposições, que serão agora confrontadas com os resultados alcançados na pesquisa:

Proposição 1 - Dada as exigências cadastrais e contratuais da Petrobras, as empresas de serviços de engenharia são obrigadas a proceder com mudanças técnicas, organizacionais e estruturais para se adequarem ao perfil dos fornecedores da contratante.

Considera-se que a proposição 1 foi confirmada. Em todas as empresas analisadas foi identificado o crescimento da estrutura física, o aumento no número de contratações de mão-de-obra específica, o aumento no número de rotinas e procedimentos e, por consequência, o aumento do número de capacitações dinâmicas na empresa. Além disso, foi percebida a adequação da própria cultura das empresas de serviços de engenharia entrevistadas, agora mais voltadas à qualidade e a excelência dos serviços prestados. 
Proposição 2 - As experiências obtidas através dos projetos executados para a Petrobras são as principais fontes para a criação das capacitações dinâmicas pelas empresas de serviços de engenharia, considerando a aprendizagem e a absorção do conhecimento obtido.

Considera-se que a proposição 2 foi confirmada. Com base na análise dos projetos realizados em cada empresa, e considerando que houve uma ordem cronológica na escolha destes, é possível afirmar que as empresas aprendem a cada novo projeto. As experiências se acumulam, assim como o conhecimento é absorvido. Parte deste conhecimento é codificado como forma de disseminar o conhecimento na organização. Esta constatação pode ser verificada através do aumento do número de rotinas criadas e/ou aperfeiçoadas a cada projeto realizado.

Respondendo a questão da pesquisa: Como se dá a construção das capacitações dinâmicas nas empresas de serviços de engenharia, a partir das exigências cadastrais e contratuais do seu principal cliente: a Petrobras?

A partir das exigências cadastrais e contratuais da Petrobras, as empresas de serviços de engenharia veem-se obrigadas a promover uma reestruturação interna e adotar novas formas e padrões de trabalho. A construção das capacitações dinâmicas ocorre através do acúmulo da experiência (aprendizado), do conhecimento e da codificação deste conhecimento sob a forma de rotinas, que poderão ser revisadas sempre que necessário, conferindo maior dinamismo aos padrões de trabalho da empresa.

Acredita-se que este trabalho de pesquisa traga contribuições teóricas, destinadas ao setor de serviços de engenharia no Brasil, mais precisamente às empresas de serviços de engenharia que atendem a Petrobras e que mostram um cenário bastante diferente se comparado às demais empresas do setor; e à comunidade acadêmica, com o aumento das publicações acerca do tema. 
Com relação à contribuição de ordem prática, entende-se que os conceitos atrelados às capacitações dinâmicas e a demonstração da sua composição poderão colaborar com as empresas que desejam codificar parte do seu conhecimento.

\subsection{LIMITAÇÕES DA PESQUISA}

O cenário das empresas de serviços de engenharia apresentados nesta pesquisa corresponde às empresas que mantém contratos com a Petrobras, não sendo prudente adotar as características aqui apresentadas para as demais empresas do setor.

É esperado que a gestão de projetos seja competência básica das empresas de serviços de engenharia. Por esse motivo, seus conceitos e características não foram aprofundados nesta pesquisa.

Os softwares e aplicativos são apresentados como rotinas criadas pela empresa, não sendo foco da pesquisa o aprofundamento das suas características técnicas.

\subsection{SUGESTÕES PARA PESQUISAS FUTURAS}

As empresas de serviços de engenharia são pouco exploradas pela literatura, exceção feita àquelas associadas a grandes construtoras que, eventualmente, aparecem como objeto de estudos de caso. Conforme citado no início do texto, o Brasil dispõe de poucas informações sobre o setor de serviços de engenharia, o que limita sobremaneira uma visão mais abrangente do setor. A existência de trabalhos dedicados a este setor poderia contribuir para o aprofundamento teórico do tema e para a discussão dos casos, corroborando ou contrapondo os resultados deste estudo. 
As possibilidades de pesquisa vislumbradas a partir deste trabalho sugerem novos estudos que visam à ampliação do conhecimento acerca do setor de serviços de engenharias:

- Obedecendo aos mesmos preceitos das pesquisas da fase 1 deste trabalho, realizar um estudo quantitativo e qualitativo nas empresas de serviços de engenharia que não tenham contratos com a Petrobras, de modo a obter uma comparação dos cenários encontrados;

- Propor um conjunto de indicadores quantitativos que possam refletir a situação das empresas de serviços de engenharia, além dos dados do emprego e do empregador. 


\section{BIBLIOGRAFIA}

ALAVI, M. LEIDNER, D. E.; Knowledge Management and Knowledge Management Systems: Conceptual Foundations and Research Issues. MIS Quaterly, v.25, n.1, pp.107-136, March, 2001.

ALVES, J. A. O Planejamento de Pesquisas Qua litativas em Educação. Caderno de Pesquisas, n.77, p.53-61, Maio, 1991.

ARGOTE, L. et al. Knowledge Transfer in Organizations: Learning from the Experience of Others. Organizational Behavior and Human Decision Processes, v.82, n.1, p.1-8, 2000.

ARGYRIS, C. Ensinando Pessoas Inteligentes a Aprender. Aprendizagem Organizacional: os melhores artigos da Harvard Business Review, Rio de Janeiro: Elsevier, 2001.

AUGIER, M.; TEECE, D. J. Understanding complex organization: the role of knowhow, internal structure, and human behavior in the evolution of capabilities. Industrial and Corporate Change, v.15, n.2, pp. 395-416, 2006.

AZMI, F. T. Mapping the learn-unlearn-relearn model: Imperatives for strategic management. European Business Review, v.20, n.3, p.240-259, 2008.

BASTOS, A. V. B.; GONDIN, S. M. G.; LOIOLA, E. Aprendizagem Organizacional versus Organizações que Aprendem: características e desafios que cercam essas duas abordagens de pesquisa. Revista Administração, São Paulo, v.39, n.3, p.220230, Jul./Ago./Set. 2004.

BATES, R. A. Public sector training participation: na empirical investigation. International Journal of Training and Development, v.5, n.2, p.136-152, 2001.

BECKER, M. C. et al. Applying organizational routines in understanding organizational change. Industrial and Corporate Change, p.1-17, 2005.

BECKER, M. C.; LAZARIC, N. The influence of knowledge in the replication of routines. Economie Appliquée LVI, n.3, p. 65-94, 2003. 
CAPRON, L.; MITCHELL, W. Selection Capability: How Capability Gaps and Internal Social Frictions Affect Internal and External Strategic Renewal. Organization Science, v.20, n.2, p.294-312, 2009.

CARLSSON, S. A.; FERNEBRO, L.; KHAKHAR, D. A framework for data communication design using a knowledge based approach. Information \& Management, v.21, p. 45-56, 1991.

CAUCHICK, P. A. M. Estudo de Caso na Engenharia de Produção: estruturação e recomendações para sua condução. Produção, v.17, n.1, p.216-229, Jan./Abr. 2007.

CEPEDA, G.; VERA, D. Dynamic capabilities and operational capabilities: A knowledge management perspective. Journal of Business Research, v.60, p.426437, 2007.

CNAE Classificação Nacional de Atividades Econômicas. Acesso em: http://www.cnae.ibge.gov.br/subclasse.asp?TabelaBusca=CNAE_200@CNAE\%202. $0 \&$ codsubclasse $=7112$

$0 / 00 \&$ codclasse $=71120 \&$ codgrupo $=711 \&$ CodDivisao $=71 \&$ CodSecao $=M$

COHEN, M. D. Routines and Other Recurring Action Patterns of Organizations: Contemporary Research Issues. Industrial and Corporate Change, n.5, p.653-697, 1996.

COHEN, W. M.; LEVINTHAL, D. A. Absortive Capacity: A New Perspective on Learning and Innovation. Administrative Science Quarterly, n.35, p.128-152, 1990.

COLLIS, D. J. How valuable are organizational capabilities? Strategic Management Journal, v. 15, p.143-152, 1994.

EASTERBY-SMITH, M. Disciplines of Organizational Learning: Contributions and Critiques. Human Relations, v.50, n.9, 1997.

EASTERBY-SMITH, M. et al. Constructing Contributions to Organizational Learning: Argyris and the Next Generation. Management Learning, 35: 371, 2004.

EASTERBY-SMITH, M.; BURGOYNE, J.; ARAUJO, L. Organizational Learning and Learning Organization - Developments in theory and practice. London: Sage Publications, 1999. 
EASTERBY-SMITH, M.; CROSSAN, M.; NICOLINI, D. Organizational Learning: Debates Past, Present and Future. Journal of Management Studies, 37:6, September, 2000.

EASTERBY-SMITH, M. et al. Constructing Contributions to Organizational Learning: Argyris and the Next Generation. Management Learning, v.35, n.4, p.371-380, 2004.

EASTERBY-SMITH, M. et al. Absortive Capacity: A Process Perspective. Management Learning, v.39, n.5, p.483-501, 2008.

EISENHARDT, K. Building Theories from Case Study Research. Academy of Management Review, v.14, n.14, pp 532-550, 1989.

EISENHARDT, K. M.; MARTIN, J. A. Dynamic Capabilities: What are they? Strategic Management Journal, v.21, p.1105-1121, 2000.

FANG, C.; LEVINTHAL, D. A. Near-Term Liability of Exploitation: Exploration and Exploitation in Multistage Problems. Organization Science, v.20, n.3, pp. 538-551, May-June 2009.

FELDMAN, M. S. Organizational routines as a source of continuous change. Organizational Science, n.11, p.611-629, 2000.

FELIN, T.; FOSS, N. J. The endogenous origins of experience, routines, and organizational capabilities: the poverty of stimulus. Journal of Institutional Economics, v.7, n.2, p.231-256, 2011.

FLEURY, A. C. C.; FLEURY, M. T. L. Estratégias Competitivas e Competências Essenciais: perspectivas para a internacionalização da indústria no Brasil. Gestão \& Produção, v.10, n.2, p.129-144, 2003.

FLEURY, A. C. C.; FLEURY, M. T. L. Estratégias Empresariais e Formação de Competências. São Paulo: Atlas, 2000.

FLEURY, M. T. L. A gestão de competência e a estratégia organizacional. In: As pessoas na organização. São Paulo: Editora Gente, 2002. 
FLEURY, M. T. L.; OLIVEIRA JR., M. M. Aprendizagem e Gestão do Conhecimento, em As Pessoas na Organização. São Paulo: Editora Gente, 2002.

FONTOURA, J. CARNEIRO, L. Experiência no gerenciamento da engenharia em empreendimentos em regime EPC. Captura em www.brasilengenharia.com.br/engenharia/2009591.

FREITAS, S. L. T .U.; SALERNO, M. S.; MISSAWA, V. Impactos da Petrobras no Desenvolvimento do Setor de Serviços de Engenharia no Brasil. In: ENCONTRO NACIONAL DE ENGENHARIA DE PRODUÇÃO, 30., 2010, São Carlos. Anais eletrônicos. Disponível em:

http://www.abepro.org.br/biblioteca/enegep2010_TN_STO_120_780_15297.pdf

GARVIN, D. A. Building a Learning Organization. Harward Business Review, JulyAugust, p.78-91, 1993.

GARVIN, D. A.; EDMONDSON, A. C.; GINO, F. Is Yours a Learning Organization? Harvard Business Review, 86 (3), pp. 109-116, 2008.

GEPHART, M. A. et al. Learning Organizations come alive. Training and Development, v.50, n.12, p.34-46, 1996.

GHAURI, P.; GRONHAUG, K.; KRISTIANLUND, J. Research Methods in Business Studies: a Pratical Guide. New Jersey: Prentice-Hall, 1995.

GUPTA, A. K.; SMITH, K. G.; SHALLEY, C. E. The Interplay Between Exploration and Exploitation. Academy of Management Journal, v.49, pp. 693-706, 2006.

HODGSON, G. M.; KNUDSEN, T. Poverty of stimulus and absence of cause: some questions for Felin and Foss. Journal of Institutional Economics, v. 7, n. 2, p. 295298, 2011.

JENSEN, M. B. et al. Forms of Knowledge and Modes of Innovation. Research Policy, v.36, pp. 680-693, 2007.

KERZNER, H. Gestão de Projetos: as melhores práticas. 2 ed. Porto Alegre: Bookman, 2006. 
KLEINER, A.; ROTH, G. Como transformar a experiência da empresa em sua melhor mestra. In: Gestão do Conhecimento. Série Harvard Busines Review Book. 2 ed. Rio de Janeiro: Campus, 2001.

LAW, K. M. Y. From Driving to Learning: The Organizational Learning Process. IEEE Engineering Management Review, v.37, n.1, First Quarter, 2009.

LAZZARINI, S.V. Estudo de Caso: Aplicabilidade e Limitações do Método para fins de Pesquisa. Economia \& Empresa, São Paulo, v.2, n.4, p.17-26, Out./Dez. 1995.

LEVINTHAL, D. A.; MARCH, J. G. The Myopia of Learning. Strategic Management Journal, v.14, pp. 95-112, 1993.

$\mathrm{MARCH}$, J. G. Exploration and Exploitation in Organizational Learning. Organization Science, v. 2/1, p.71-87, 1991.

MARCONI, M. A.; LAKATOS, E. M. Fundamentos de Metodologia Científica. 8 ed. São Paulo: Atlas, 2006.

MCQUEEN, R. Four Views of Knowledge and Knowledge Management. In Proceedings of AMERICAS CONFERENCE ON INFORMATION SYSTEMS, v.4, p.609-611, August, 1998.

MIGUEL, P.A.C. Adoção do Estudo de Caso na Engenharia de Produção. In: Metodologia de Pesquisa em Engenharia de Produção e Gestão de Operações. Rio de Janeiro: Elsevier, 2010.

MINTZBERG, H. Crafting Strategy. Harvard Business Review, July-August, 1987.

MINTZBERG, H.; AHLMSTRAND, B.; LAMPEL. J. Safari de Estratégia: um roteiro pela selva do planejamento estratégico. Porto Alegre: Bookman, 2000.

NAKANO, D. N.; FLEURY, A. C. C. Conhecimento Organizacional: uma revisão conceitual dos modelos e quadros de referência. Produto \& Produção, v. 8, n. 2, p. 11-23, 2005.

NELSON, R. R. Why do firms differ, and how does it matter? Strategic Management Journal, v. 12, p.61-74, 1991. 
NELSON, R. R.; WINTER, S. G. Uma teoria evolucionária da mudança econômica. Cap.5, p. 149-205. Campinas: Editora Unicamp, 2005.

NONAKA, I. A empresa criadora do conhecimento. In: Gestão do Conhecimento. Série Harvard Busines Review Book. 2. ed. Rio de Janeiro: Campus, 2001.

NONAKA, I. et al. Organizational Knowledge Creation Theory: A First Comprehensive Test. International Business Review, v.3, n.4, p.337-351, 1994.

NONAKA, I.; TAKEUCHI, H. Criação de Conhecimento na Empresa. Rio de Janeiro: Campus, 1997.

OLAVE, M. E. L.; AMATO NETO, J. Redes de Cooperação Produtiva: uma estratégia de competitividade e sobrevivência para pequenas e médias empresas. Gestão \& Produção, v.8, n.3, p.289-303, Dezembro, 2001.

PATTON, M. Q. Qualitative Research and Evaluation Methods. 3 ed. Califórnia: Sage, 2002.

PATTON, M. Q. Enhancing the Quality and Credibility of Qualitative Analysis. HSR: Health Services Research, v.34, n.5, Part II, December, 1999.

PAVLOU, P. A.; SAWY, O. A. E. Understanding the Black Box of Dynamic Capabilities. Management Science,

PENROSE, E. A Teoria do Crescimento da Firma. São Paulo: Atlas, 1995.

PENTLAND, B. T. The foundation is solid, if you know where to look: comment on Felin and Foss. Journal of Institutional Economics, v.7, n.2, p.279-293, 2011.

PRIETO, I. M.; EASTERBY-SMITH, M. Dynamic capabilities and the role of organizational knowledge: an exploration. European Journal of Information Systems, v.15, p.500-510, 2006.

QUINN, J. B.; ANDERSON, P.; FINKELSTEIN, S. Gerenciando o intelecto profissional: extraindo o máximo dos melhores. In: Gestão do Conhecimento. Série Harvard Business Review Book. 2. ed. Rio de Janeiro: Campus, 2001. 
REVISTA VEJA. Acervo digital. Acesso em 15/01/2012. Disponível em: http://veja.abril.com.br/noticia/economia/petrobras-e-a-oitava-maior-empresa-domundo-segundo-a-forbes

SALERNO, M. S.; FREITAS, S. L. T. U.; MISSAWA, V. A Influência da Petrobras no Desenvolvimento Tecnológico: O Caso das Empresas de Serviços de Engenharia. In: João Alberto De Negri (et al.). (Org.). Poder de Compra da Petrobras Impactos econômicos nos seus fornecedores. 1 ed. Brasília: Ipea/Petrobras, 2011, v. 2, p. 441-494.

SANTOS, F. M.; EISENHARDT, K. M. Organizational Boundaries and Theories of Organization. Organization Science, v.16, n.5, p.491-508, September/October 2005.

SCARBROUGH, $\mathrm{H}$. et al. Project-Based Learning and the Role of Learning Boundaries. Organizational Studies, v.25, n.9, p.1579-1600, 2004.

SENGE, P. M. A Quinta Disciplina - Arte e Prática da Organização que Aprende. 25 ed. Rio de Janeiro: BestSeller, 2009.

TAKAHASHI, S.; TAKAHASHI, V. P. Gestão de Inovação de Produtos: Estratégia, Processo, Organização e Conhecimento. Rio de Janeiro: Campus, 2007.

TEECE, D. J. Explicating Dynamic Capabilities: The Nature and Microfoundations of (Sustainable) Enterprise Performance. Strategic Management Journal, v.28, pp. 1319-1350, 2007.

TEECE, D. J.; PISANO, G. The dynamic capabilities of firms: An introduction. Industrial and Corporate Change, v.3, p.537-556, 1994.

TEECE, D. J.; PISANO, G.; SHUEN A. Dynamic Capabilities and Strategic Management. Strategic Management Journal, v.18, n.7, p.509-533, 1997.

TIDD, J.; BESSANT, J.; PAVITT, K. Gestão da Inovação. 3 ed. Porto Alegre: Bookman, 2008.

VERGARA, S. C. Projetos e Relatórios de Pesquisa em Administração. 10 ed. São Paulo: Atlas, 2009. 
VOSS, C.; TSIKRIKTSIS, N.; FROHLICH, M. Case research in operations management. International Journal of Operations \& Production Management, v.22, n.2, p.195-219, 2002.

WELDY, T. G. Learning organization and transfer: strategies for improving performance. The Learning Organization, v. 16, n. 1, p. 58-68, 2009.

WEST, P. The learning organization: losing the luggage in transit. Journal of European Industrial Training, v.18, n.11, p. 30-38, 1994.

WILLIAMSON, O. E. Strategy Research: Governance and Competence Perspectives. Strategic Management Journal, v. 20, n.12, p. 1087-1108, 1999.

WINKELEN, C. V. Deriving value from inter-organizational learnings collaborations. The Learning Organization, v.17, n.1, p. 8-23, 2010.

WINTER, S. G. Problems at the Foundation? Comments on Felin and Foss. Journal of Institutional Economics, v.7, n.2, p.257-277, 2011.

WINTER, S. G. The Satisficing Principle in Capability Learning. Strategic Management Journal, v.21, pp. 981-996, 2000.

WINTER, S. G. Understanding Dynamic Capabilities. Strategic Management Journal, v.24, p.991-995, 2003.

YIN, R. K. Case study research. Design and methods. 2. Ed. USA: Sage Publications, 1994.

ZAHRA, S. A.; GEORGE, G. Absortive Capacity: A Review, Reconceptualization, and Extension. Academy of Management Review, v.27, n.2, p. 185-203, 2002.

ZOLLO, M.; WINTER, S. G. Deliberate Learning and the Evolution of Dynamic Capabilities. Organization Science, v.13, p. 339-351, 2002. 


\section{APÊNDICE 1 - Roteiro de levantamento de campo (fase 1)}

1. Há quanto tempo a empresa tem relações contratuais de fornecimento e prestação de serviços com a Petrobrás?

2. Quais as principais exigências, ou requisitos, da Petrobrás, para que a empresa de engenharia esteja apta a participar das concorrências / licitações?

3. A que se atribui o ganho dos contratos, além da competência técnica e preço?

4. Houve alguma mudança estrutural na empresa devido aos contratos com a Petrobrás? Criou-se alguma atividade ou ferramenta específica para atendêlos?

5. Há contratações específicas para os projetos da Petrobrás?

6. O que a empresa aprendeu com a Petrobrás, e como foi o aprendizado?

7. Desenvolvimento e experiência com a Petrobrás são fatores qualificadores e/ou ganhadores de pedidos junto a outros clientes / mercados?

8. O que a empresa tem feito, ou pensa fazer, para manter as relações com a Petrobrás?

9. Se hoje a Petrobrás retirar esta empresa do cadastro de fornecedores, qual seria o impacto?

10. Quais as expectativas da empresa para o futuro? 
APÊNDICE 2 - Roteiro de levantamento de campo (fase 2)

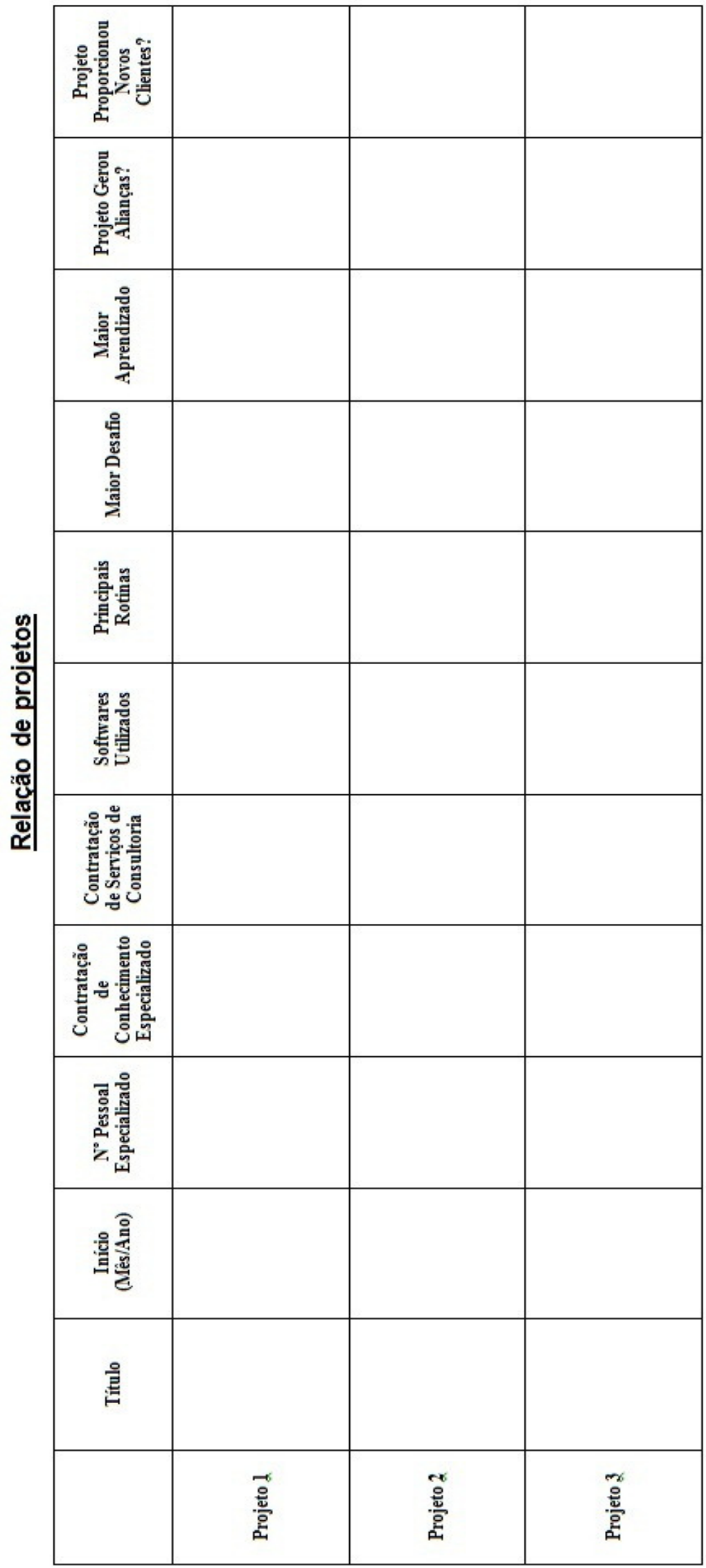

